\title{
WestVirginiaUniversity
}

THE RESEARCH REPOSITORY @ WVU

Graduate Theses, Dissertations, and Problem Reports

2006

\section{Partial oxidation of propane on ceria- and alumina-supported platinum catalysts}

Vijaya Anil Bansode

West Virginia University

Follow this and additional works at: https://researchrepository.wvu.edu/etd

\section{Recommended Citation}

Bansode, Vijaya Anil, "Partial oxidation of propane on ceria- and alumina-supported platinum catalysts" (2006). Graduate Theses, Dissertations, and Problem Reports. 1693.

https://researchrepository.wvu.edu/etd/1693

This Thesis is protected by copyright and/or related rights. It has been brought to you by the The Research Repository @ WVU with permission from the rights-holder(s). You are free to use this Thesis in any way that is permitted by the copyright and related rights legislation that applies to your use. For other uses you must obtain permission from the rights-holder(s) directly, unless additional rights are indicated by a Creative Commons license in the record and/ or on the work itself. This Thesis has been accepted for inclusion in WVU Graduate Theses, Dissertations, and Problem Reports collection by an authorized administrator of The Research Repository @ WVU. For more information, please contact researchrepository@mail.wvu.edu. 


\title{
Partial oxidation of propane on ceria-and alumina-supported platinum catalysts
}

\author{
Vijaya Anil Bansode
}

Thesis submitted to the College of Engineering and Mineral Resources at West Virginia University in partial fulfillment of the requirements

for the degree of

Master of Science
in
Chemical Engineering

Dr. Edwin L. Kugler, Chair

Dr. Dady B. Dadyburjor

Mr. David Berry

Department of Chemical Engineering

Morgantown, West Virginia

2006

Keywords: Propane, autothermal reforming, partial oxidation, reaction scheme, ceria supported platinum catalyst, alumina supported platinum catalyst 


\section{Abstract \\ Partial Oxidation of Propane on Ceria-and-Alumina Supported Platinum Catalysts}

\section{Vijaya Anil Bansode}

Three $\mathrm{Pt} / \mathrm{CeO}_{2}$ catalysts and $\mathrm{Pt} / \mathrm{Al}_{2} \mathrm{O}_{3}$ catalyst were studied for partial oxidation of propane. The $1 \% \mathrm{Pt} / \mathrm{CeO}_{2}(\mathrm{C})$ catalyst which was prepared using $\mathrm{CeO}_{2}$ prepared by the decomposition technique showed the highest propane conversion and hydrogen selectivity. The $1 \% \mathrm{Pt} / \mathrm{Al}_{2} \mathrm{O}_{3}$ showed better performance than $1 \% \mathrm{Pt} / \mathrm{CeO}_{2}(\mathrm{C})$.

The effect of flow rate was studied for $0.01 \mathrm{~g}$ and $0.02 \mathrm{~g}$ of $1 \% \mathrm{Pt} / \mathrm{CeO}_{2}(\mathrm{C})$ and 1

$\% \mathrm{Pt} / \mathrm{Al}_{2} \mathrm{O}_{3}$. Oxygen is totally consumed at all flow rates, even at $0.01 \mathrm{~g}$ catalyst loading for both catalysts. The total oxidation of propane is taking place first followed by steam reforming along with water gas shift and reverse Boudouard reactions. Water gas shift dominates over reverse Boudouard and is very close to equilibrium on $1 \% \mathrm{Pt} / \mathrm{CeO}_{2}(\mathrm{C})$. This indicates that ceria promotes water gas shift, whereas reverse Boudouard dominates over water gas shift on $1 \% \mathrm{Pt} / \mathrm{Al}_{2} \mathrm{O}_{3}$. 
Dedicated to my grandfather, late Mr. Shivaji R. Bansode 


\section{Acknowledgements}

I am extremely grateful to my advisors Dr. Dady Dadyburjor and Dr. Edwin Kugler, for the invaluable guidance, help, time and encouragement they gave me during my graduate studies at West Virginia University. I am thankful to Mr. David Berry of

National Energy Technology Laboratory, my research committee member, for his valuable suggestions and comments. The financial support from US Department of Energy is gratefully acknowledged.

I sincerely thank Dr. Tapan Das for all his help throughout this research work. I would like to express my appreciation to James Wright for carrying out BET surface area measurements. I thank my colleagues at reaction engineering laboratory, Dr. Wenping Ma and Huifang Shao for their input in my research.

I would like to thank Bonita Helmick and Linda Rogers for patiently helping me out in all important non-academic issues. I am thankful to every faculty and graduate student at West Virginia University who made my stay in Morgantown a memorable and valuable experience.

I am grateful to my parents, my grandmother, my aunt Dr. Aruna Mane and all my relatives for their motivation and support in good and in trying times. Finally I would like to thank all my friends Ajay Joshi, Aditi, Archana, Kedhar and Sandy who made these two years a wonderful experience to cherish forever. 


\section{Table of Contents}

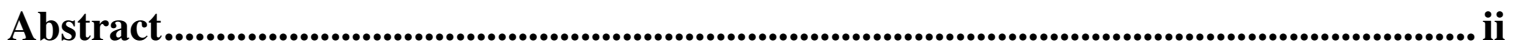

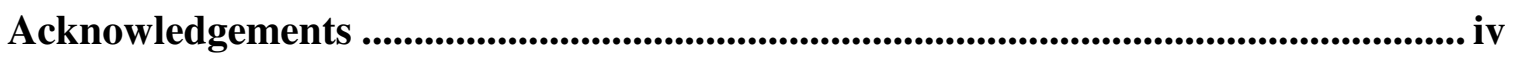

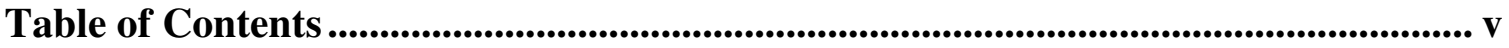

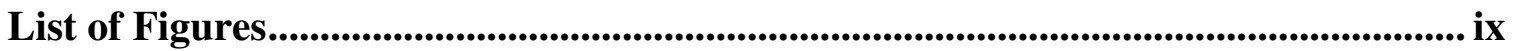

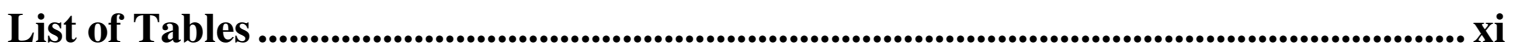

Chapter 1: Introduction ....................................................................................................................... 1

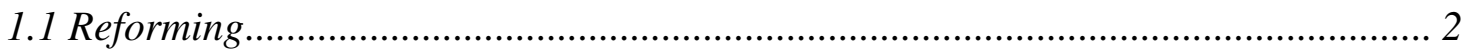

1.2 Significance of Steam Reforming and Partial Oxidation...................................... 3

1.3 Significance of Autothermal Reforming ............................................................... 4

1.4 Statement of Problem and Objectives ........................................................... 4

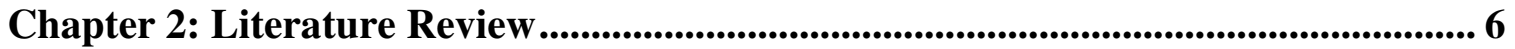

2.1. Thermodynamics of Propane Oxidation .............................................................. 6

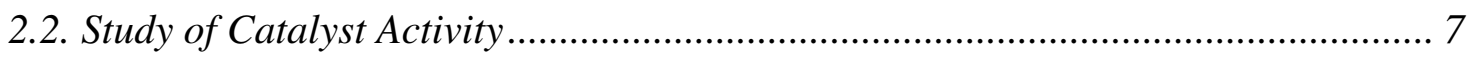

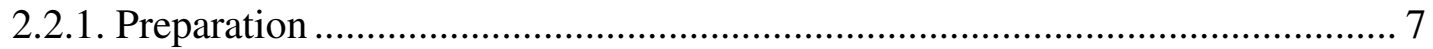

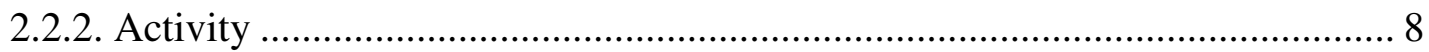

2.2.3. Effect of Catalyst System................................................................. 9

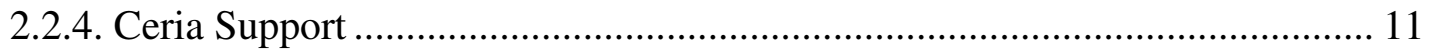

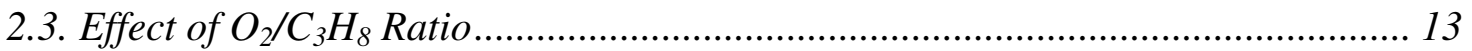

2.4. Effect of Steam Addition................................................................................. 13

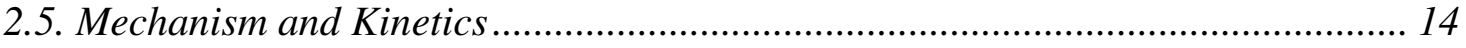

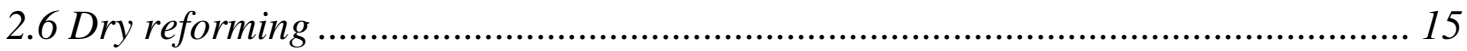

2.7 Water gas shift reaction ............................................................................. 15

Chapter 3: Experimental Set Up and Procedure

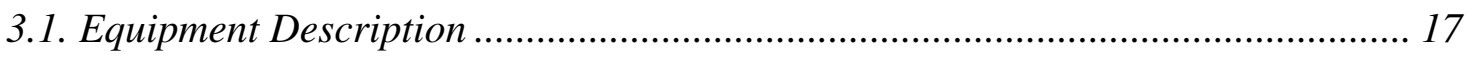

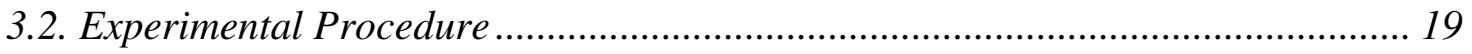

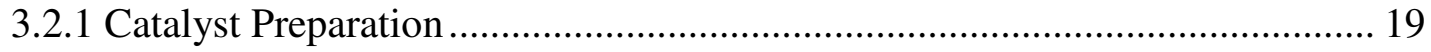

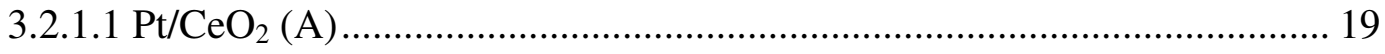




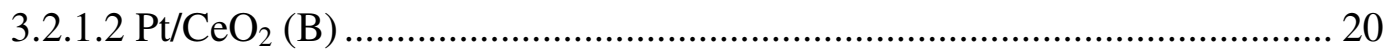

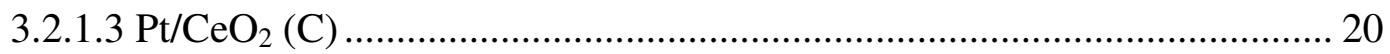

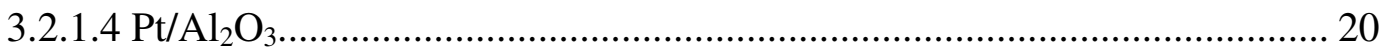

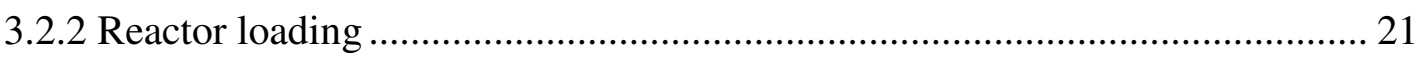

3.2.3 Pretreatment and Reaction ......................................................................... 21

3.2.4 Materials and Methodology ……………………................................... 22

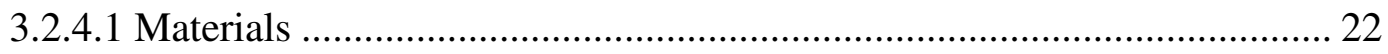

3.2.4.2 Effect of Temperature ……………………….................................... 22

3.2.4.3 Study of thermal stability of supports and catalysts ................................ 22

3.2.4.4 Study of stability of catalyst for partial oxidation of propane .................. 23

3.2.4.5 Effect of $\mathrm{O}_{2} / \mathrm{C}_{3} \mathrm{H}_{8}$ ratio......................................................................... 23

3.2.4.6 Study of ceria and alumina support .......................................................... 23

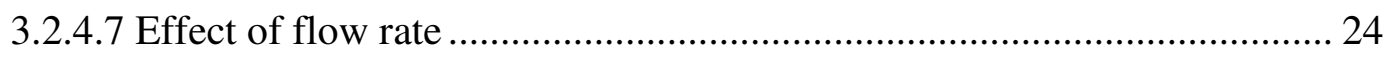

3.2.4.8 Dry reforming of propane ……………………................................ 24

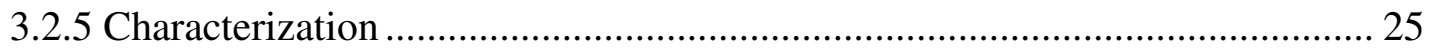

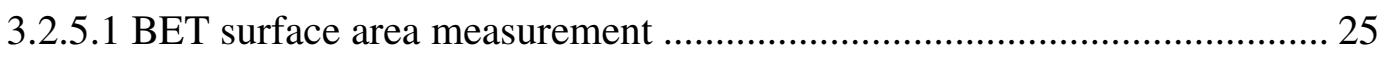

3.2.5.2 Platinum dispersion measurement ........................................................ 25

3.2.6 Safety Requirements ............................................................................ 25

Chapter 4: Effect of Temperature.......................................................................................... 27

4.1 Preliminary Results.................................................................................. 27

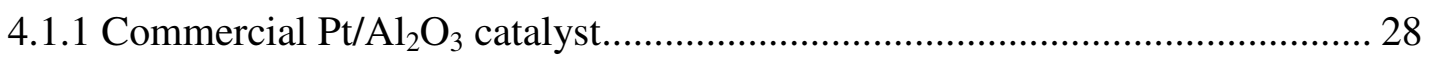

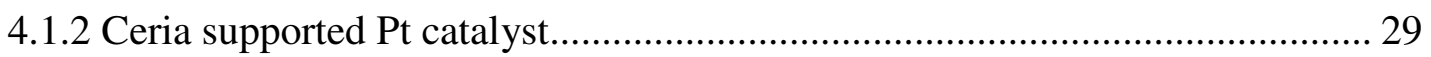

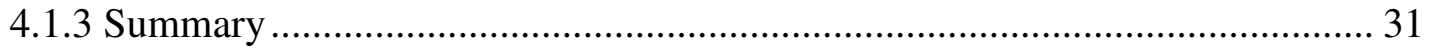

4.2 Effect of support on partial oxidation of propane ……………………………..... 32

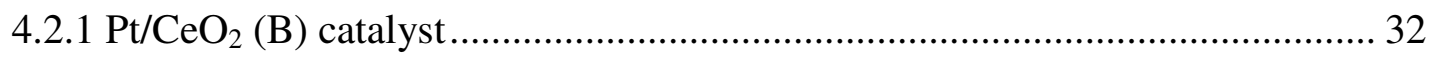

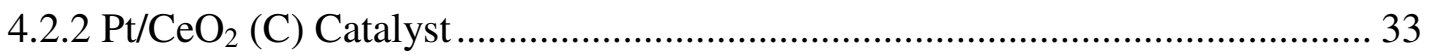

4.2.3 Pt/ $\mathrm{Al}_{2} \mathrm{O}_{3}$ Catalyst ............................................................................... 35

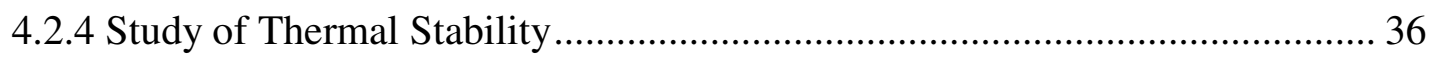

4.2.5 Platinum dispersion studies...................................................................... 36

4.2.6 Comparison of the catalysts ............................................................................ 37 
Chapter 5: Effect of Time on Stream and Feed Ratio for $1 \% \mathrm{Pt}^{-\mathrm{CeO}_{2}}(\mathrm{C})$ and $1 \%$

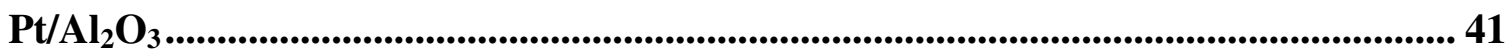

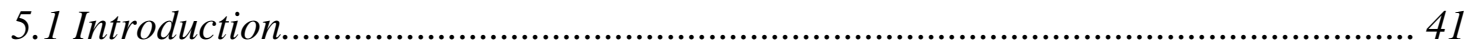

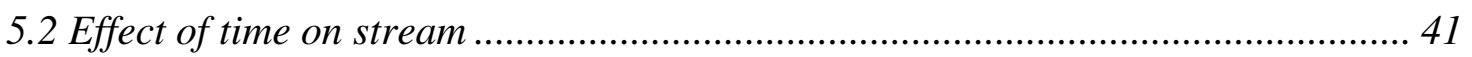

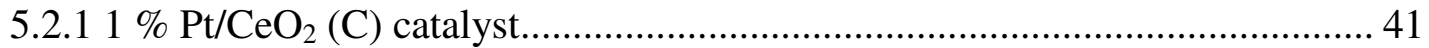

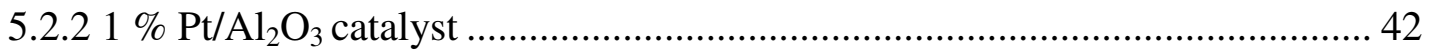

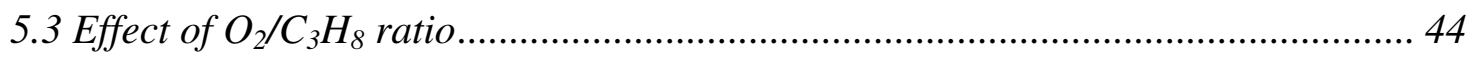

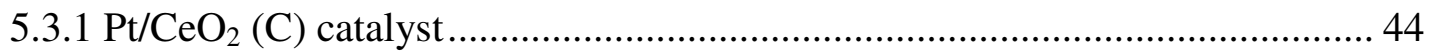

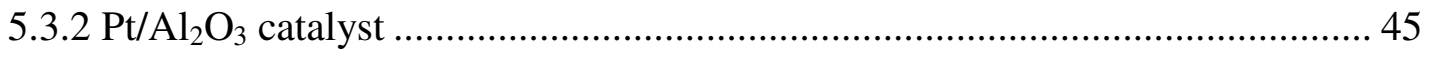

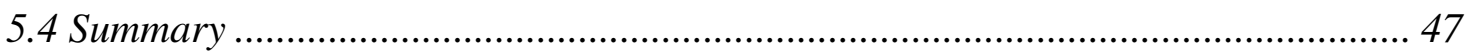

Chapter 6: Effect of Flow Rate on Partial Oxidation of Propane .................................. 48

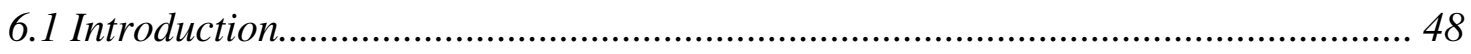

6.2 Study of support for partial oxidation of propane …………………………....... 49

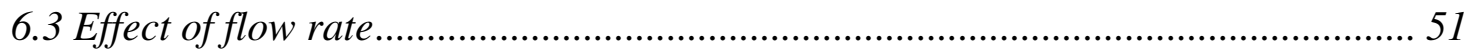

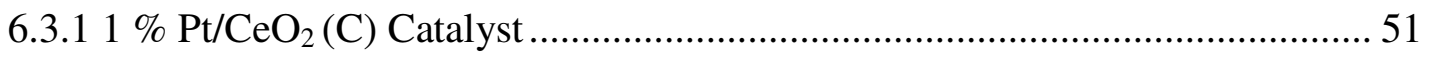

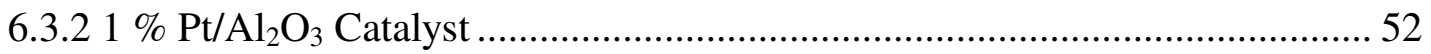

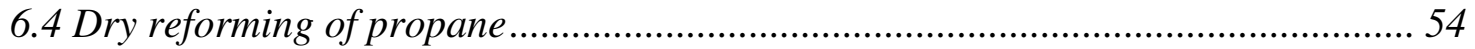

6.5 Reaction scheme

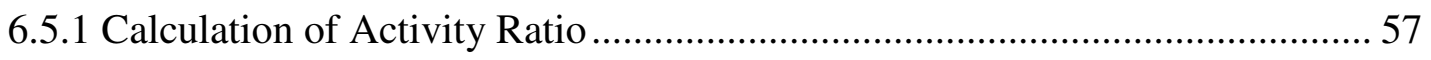

6.5.2 Role of Water Gas Shift and Reverse Boudouard Reactions............................ 58

6.5.3 Comparison for ceria-and-alumina supported catalysts................................... 59

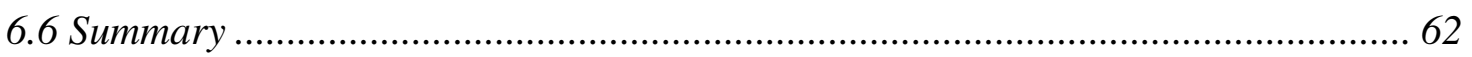

Chapter 7: Summary and Recommendations for Future Work .................................... 63

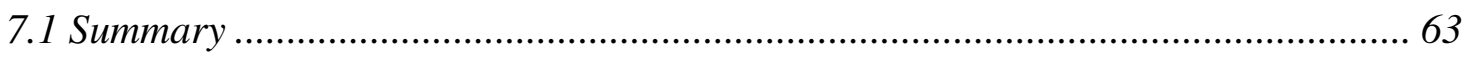

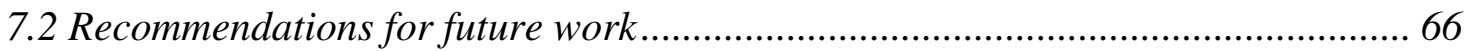




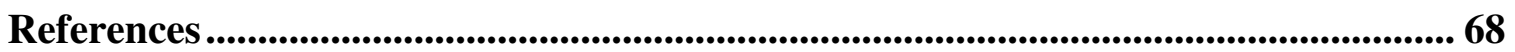

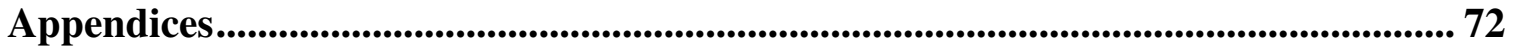

Appendix A: Gas Chromatograph Program ......................................................................... 73

Appendix B: Mass Flow Controller Calibration Curves............................................. 76

Appendix C: Calculations for Conversions and Selectivities.......................................... 78 


\section{List of Figures}

Figure 3.1 Flow sheet for Catalyst Testing Unit. 18

Figure 4.1 Effect of temperature on activities and product distribution over $5 \% \mathrm{Pt} / \mathrm{Al}_{2} \mathrm{O}_{3}$ commercial catalyst (Feed ratio: $\mathrm{O}_{2} / \mathrm{C}_{3} \mathrm{H}_{8}=1.78$, total feed rate: $300 \mathrm{scc} / \mathrm{min}$ )

Figure 4.2 Effect of temperature on activities and product distribution over $0.5 \%$

$\mathrm{Pt} / \mathrm{CeO}_{2}$ (A) catalyst (Feed ratio: $\mathrm{O}_{2} / \mathrm{C}_{3} \mathrm{H}_{8}=1.78$, total feed rate: $300 \mathrm{scc} / \mathrm{min}$ )

Figure 4.3 Effect of temperature on activities and product distribution over $1 \% \mathrm{Pt} / \mathrm{CeO}_{2}$

(B) catalyst (Feed ratio: $\mathrm{O}_{2} / \mathrm{C}_{3} \mathrm{H}_{8}=1.78$, total feed rate: $300 \mathrm{scc} / \mathrm{min}$ ) 33

Figure 4.4 Effect of temperature on activities and product distribution over $1 \% \mathrm{Pt} / \mathrm{CeO}_{2}$

(C) catalyst (Feed ratio: $\mathrm{O}_{2} / \mathrm{C}_{3} \mathrm{H}_{8}=1.78$, total feed rate: $300 \mathrm{scc} / \mathrm{min}$ ). 34

Figure 4.5 Effect of temperature on activities and product distribution over $1 \% \mathrm{Pt} / \mathrm{Al}_{2} \mathrm{O}_{3}$ catalyst (Feed ratio: $\mathrm{O}_{2} / \mathrm{C}_{3} \mathrm{H}_{8}=1.78$, total feed rate: $300 \mathrm{scc} / \mathrm{min}$ ). 35

Figure 4.6 a Comparison of activities of $1 \% \mathrm{Pt} / \mathrm{CeO}_{2}$ and $1 \% \mathrm{Pt} / \mathrm{Al}_{2} \mathrm{O}_{3}$ catalysts (Total flow rate $=300 \mathrm{scc} / \mathrm{min}, \mathrm{O}_{2} / \mathrm{C}_{3} \mathrm{H}_{8}=1.78$, amount of catalyst $\left.=0.1 \mathrm{~g}\right) \ldots \ldots . .38$

Figure $4.6 \mathrm{~b}$ Comparison of $\mathrm{H}_{2}$ selectivities of $1 \% \mathrm{Pt} / \mathrm{CeO}_{2}$ and $1 \% \mathrm{Pt} / \mathrm{Al}_{2} \mathrm{O}_{3}$ catalysts (Total flow rate $=300 \mathrm{scc} / \mathrm{min}, \mathrm{O}_{2} / \mathrm{C}_{3} \mathrm{H}_{8}=1.78$, amount of catalyst $=0.1 \mathrm{~g}$ )

Figure 4.6 c Comparison of $\mathrm{CO}$ selectivities of $1 \% \mathrm{Pt} / \mathrm{CeO}_{2}$ and $1 \% \mathrm{Pt} / \mathrm{Al}_{2} \mathrm{O}_{3}$ catalysts (Total flow rate $=300 \mathrm{scc} / \mathrm{min}, \mathrm{O}_{2} / \mathrm{C}_{3} \mathrm{H}_{8}=1.78$, amount of catalyst $=0.1 \mathrm{~g}$ )

Figure $4.6 \mathrm{~d}$ Comparison of $\mathrm{CO}_{2}$ selectivities of $1 \% \mathrm{Pt} / \mathrm{CeO}_{2}$ and $1 \% \mathrm{Pt} / \mathrm{Al}_{2} \mathrm{O}_{3}$ catalysts (Total flow rate $=300 \mathrm{scc} / \mathrm{min}, \mathrm{O}_{2} / \mathrm{C}_{3} \mathrm{H}_{8}=1.78$, amount of catalyst $=0.1 \mathrm{~g}$ )

Figure 5.1 Stability of $1 \% \mathrm{Pt} / \mathrm{CeO}_{2}(\mathrm{C})$ for propane activity and product selectivities against time on stream $\left(\mathrm{T}=800^{\circ} \mathrm{C}\right.$, total flow rate $=300 \mathrm{scc} / \mathrm{min}$ with $90 \%$ inert).

Figure 5.2 Stability of $1 \% \mathrm{Pt} / \mathrm{Al}_{2} \mathrm{O}_{3}$ for propane activity and product selectivities against time on stream $\left(\mathrm{T}=600{ }^{\circ} \mathrm{C}\right.$, total flow rate $=300 \mathrm{sccm}$ with $90 \%$ inert $) \ldots . .43$ 
Figure 5.3 Effect of $\mathrm{O}_{2} / \mathrm{C}_{3} \mathrm{H}_{8}$ ratio on partial oxidation of propane on $1 \% \mathrm{Pt} / \mathrm{CeO}_{2}(\mathrm{C})$ catalyst $\left(\mathrm{T}=675^{\circ} \mathrm{C}\right.$, total flow rate $=300 \mathrm{scc} / \mathrm{min}$ with $90 \%$ inert $)$ 45

Figure 5.4 Effect of $\mathrm{O}_{2} / \mathrm{C}_{3} \mathrm{H}_{8}$ ratio on partial oxidation of propane on $1 \% \mathrm{Pt} / \mathrm{Al}_{2} \mathrm{O}_{3}$ catalyst $\left(\mathrm{T}=675^{\circ} \mathrm{C}\right.$, total flow rate $=300 \mathrm{scc} / \mathrm{min}$ with $90 \%$ inert $)$ 46

Figure 6.1 Effect of flow rate on $1 \% \mathrm{Pt} / \mathrm{CeO}_{2}(\mathrm{C})$ catalyst activity and product distribution for partial oxidation of propane $\left(\mathrm{T}=600{ }^{\circ} \mathrm{C}, \mathrm{O}_{2} / \mathrm{C}_{3} \mathrm{H}_{8}=1.77,90\right.$ $\%$ inert; $1-0.01 \mathrm{~g}$ and 2-0.02 g catalyst weight)

Figure 6.2 Effect of flow rate on $1 \% \mathrm{Pt} / \mathrm{Al}_{2} \mathrm{O}_{3}$ catalyst activity and product distribution for partial oxidation of propane $\left(\mathrm{T}=600{ }^{\circ} \mathrm{C}, \mathrm{O}_{2} / \mathrm{C}_{3} \mathrm{H}_{8}=1.77,90 \%\right.$ inert; 1 $0.01 \mathrm{~g}$ and 2-0.02 g catalyst weight)

Figure 6.3 Effect of catalyst amount and support on activity ratio $J_{W G S}$ at different flow rates $\left(\mathrm{T}=600{ }^{\circ} \mathrm{C}, \mathrm{O}_{2} / \mathrm{C}_{3} \mathrm{H}_{8}=1.77,90 \%\right.$ inert $)$

Figure 6.4 Effect of catalyst amount and support on activity ratio $J_{R B}$ at different flow rates $\left(\mathrm{T}=600{ }^{\circ} \mathrm{C}, \mathrm{O}_{2} / \mathrm{C}_{3} \mathrm{H}_{8}=1.77,90 \%\right.$ inert $)$

Figure A.1 A typical chromatograph obtained from TCD for partial oxidation of propane over commercial $5 \% \mathrm{Pt} / \mathrm{Al}_{2} \mathrm{O}_{3}$ catalyst (Reaction conditions: $\mathrm{T}=500{ }^{\circ} \mathrm{C}$, Feed ratio $=\mathrm{C}_{3} \mathrm{H}_{8}: \mathrm{O}_{2}: \mathrm{N}_{2}: \mathrm{Ar}=10.8: 19.2: 10.8: 259$ )

Figure A.2 A typical chromatograph obtained from FID for partial oxidation of propane over commercial $5 \% \mathrm{Pt} / \mathrm{Al}_{2} \mathrm{O}_{3}$ catalyst (Reaction conditions: $\mathrm{T}=500{ }^{\circ} \mathrm{C}$, Feed ratio $\left.=\mathrm{C}_{3} \mathrm{H}_{8}: \mathrm{O}_{2}: \mathrm{N}_{2}: \mathrm{Ar}=10.8: 19.2: 10.8: 259\right)$ 75

Figure B.1 MFC calibration curve for $\mathrm{C}_{3} \mathrm{H}_{8} / \mathrm{N}_{2} / \mathrm{Ar}$ mixture ......................................... 76

Figure B.2 MFC calibration curve for $\mathrm{O}_{2} / \mathrm{Ar}$ mixture ………….................................... 76

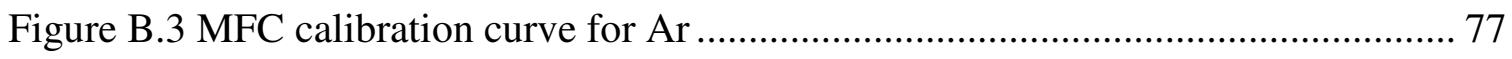

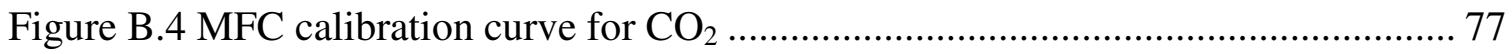




\section{List of Tables}

Table 2.1 Compilation of various catalyst systems investigated for partial oxidation and autothermal reforming (S/C-Steam to carbon ratio; $\mathrm{X}_{\mathrm{C} 3 \mathrm{H} 8^{-}}$Conversion of

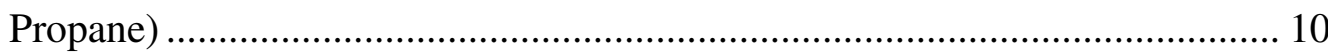

Table 2.2 Effect of S/C ratio on autothermal reforming of propane.............................. 13

Table 2.3 Effect of S/C ratio on autothermal reforming of propane (Guimaraes et al., 2003)

Table 2.4 Parameters of the power law Equation 2.12

Table 4.1 Effect of temperature on the activity of the stainless-steel reactor for partial oxidation of propane (total flow rate $=300 \mathrm{scc} / \mathrm{min}, \mathrm{O}_{2} / \mathrm{C}_{3} \mathrm{H}_{8}=1.78$ ).

Table 4.2 Effect of time on stream on stability of the $0.5 \% \mathrm{Pt} / \mathrm{CeO}_{2}(\mathrm{~A})$ catalyst at $700^{\circ}$

$\mathrm{C}$ (Feed ratio: $\mathrm{O}_{2} / \mathrm{C}_{3} \mathrm{H}_{8}=1.78$, total feed rate: $300 \mathrm{scc} / \mathrm{min}$ )

Table 4.3 Thermal stability analysis of different ceria supports and catalysts ................ 36

Table 4.4 Platinum dispersion of ceria and alumina supported Pt catalysts ................... 37

Table 6.1 Effect of temperature on the activity of the quartz reactor for partial oxidation of propane (total flow rate $=300 \mathrm{scc} / \mathrm{min}, \mathrm{O}_{2} / \mathrm{C}_{3} \mathrm{H}_{8}=1.78$ )

Table 6.2 Partial oxidation of propane on $\mathrm{CeO}_{2}(\mathrm{C})$ and $\gamma-\mathrm{Al}_{2} \mathrm{O}_{3}$ supports $($ Temperature $=$

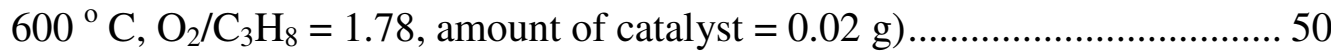

Table 6.3 Comparison of dry reforming and partial oxidation of propane (Temperature = $600{ }^{\circ} \mathrm{C}$, Catalyst amount $=0.02 \mathrm{~g}$, Dry Reforming: $\mathrm{CO}_{2} / \mathrm{C}_{3} \mathrm{H}_{8}=3,86 \%$ inert $\left(\mathrm{N}_{2}+\mathrm{Ar}\right)$; Partial Oxidation: $\mathrm{O}_{2} / \mathrm{C}_{3} \mathrm{H}_{8}=1.78,90 \%$ inert $\left.\left(\mathrm{N}_{2}+\mathrm{Ar}\right)\right)$.............. 55

Table C.1 Relative response factors for the reactants and products .............................. 78 


\section{Chapter 1: Introduction}

There has been increasing demand for hydrogen as a clean fuel for fuel cells. Hydrogen can be manufactured from solar cells or hydropower by means of electrolysis of water, but these processes do not supply enough hydrogen for potential hydrogen demand. This problem can be solved by multi-step processing of hydrocarbon-based fuels to derive hydrogen efficiently (Ayabe et al., 2003).

Fuel cells can be used for transportation and also for stationary and portable power generation. The advantages of fuels cells are their high efficiency and lower emissions of pollutants. Fuel cells will lower emission of pollutants such as carbon monoxide, nitrogen oxides $\left(\mathrm{NO}_{\mathrm{x}}\right)$ and sulfur oxides $\left(\mathrm{SO}_{\mathrm{x}}\right)$. Fuel cells can operate on hydrogen, but the constraint on using hydrogen-fueled vehicles is hydrogen refueling and hence storage of hydrogen.

The alternative to storage of hydrogen in a vehicle is to carry fuels and convert them to hydrogen via an on-board fuel processor. All these fuels are hydrocarbons or oxygenates that need to be reformed. Reforming processes such as steam reforming, partial oxidation or autothermal reforming can carry out the reforming of a hydrocarbon to syngas. The carbon dioxide and carbon monoxide are removed from the product gases by variety of scrubbing techniques and reactions such as $\mathrm{CO}_{2}$ absorption in amine solution, water gas shift reaction and preferential oxidation. (Ahmed and Krumpelt, 2001). 


\subsection{Reforming}

Hydrocarbon fuels $\left(C_{n} H_{m}\right)$ can be converted to syngas by a process known as reforming. Reforming can be carried out in three different ways (Ahmed and Krumpelt, 2001):

- The first way is Steam Reforming. It can be shown as follows:

$$
\mathrm{C}_{n} \mathrm{H}_{m}+n \mathrm{H}_{2} \mathrm{O} \rightarrow n \mathrm{CO}+\left(n+\frac{1}{2} m\right) \mathrm{H}_{2}
$$

For example:

$$
\mathrm{CH}_{4}+\mathrm{H}_{2} \mathrm{O} \rightarrow \mathrm{CO}+3 \mathrm{H}_{2} \quad \Delta H_{298}^{0}=206.2 \mathrm{~kJ} / \mathrm{mol} \quad \text { Equation } 1.2
$$

Steam reforming is catalyzed by nickel or a noble metal catalyst.

- The second way is Partial Oxidation which can be shown as follows:

$$
\begin{array}{ll}
C_{n} H_{m}+\frac{1}{2} n O_{2} \rightarrow n C O+\frac{1}{2} m H_{2} & \text { Equation } 1.3
\end{array}
$$

For example:

$$
\mathrm{CH}_{4}+\frac{1}{2} \mathrm{O}_{2} \rightarrow \mathrm{CO}+2 \mathrm{H}_{2} \quad \Delta H_{298}^{0}=-35.6 \mathrm{~kJ} / \mathrm{mol} \quad \text { Equation } 1.4
$$

- The third way is Autothermal Reforming

Autothermal reforming can be defined as the combination of total oxidation and hydrogen production where both steam and oxygen are added. Here complete oxidation furnishes the thermal energy required for $\mathrm{H}_{2}$ production.

A nominal reaction can be written as:

$$
\begin{array}{r}
\mathrm{C}_{n} \mathrm{H}_{m} \mathrm{O}_{p}+x\left(\mathrm{O}_{2}+3.76 \mathrm{~N}_{2}\right)+(2 n-2 x-p) \mathrm{H}_{2} \mathrm{O}(l) \rightarrow n \mathrm{CO}_{2}+\left(2 n-2 x-p+\frac{m}{2}\right) \mathrm{H}_{2}+3.76 x N_{2} \\
\text { Equation } 1.5
\end{array}
$$

where $\mathrm{x}$ is the oxygen-to-fuel molar ratio. 
Equation 1.5 assumes that autothermal reforming consists of steam reforming and total oxidation, that no net carbon monoxide is formed and that there is a net loss of water.

For example:

$$
\begin{array}{ll}
\mathrm{CH}_{4}+x\left(\mathrm{O}_{2}+3.76 \mathrm{~N}_{2}\right)+(2-2 x) \mathrm{H}_{2} \mathrm{O}(\mathrm{l}) \rightarrow \mathrm{CO}_{2}+(4-2 x) \mathrm{H}_{2}+3.76 x \mathrm{~N}_{2} & \\
\Delta H_{298}^{0}=252.77-571.13 x \mathrm{~kJ} / \mathrm{mol} & \text { Equation } 1.6
\end{array}
$$

\subsection{Significance of Steam Reforming and Partial Oxidation}

Hydrogen is manufactured commercially using steam and hydrocarbons over a nickel catalyst by steam reforming. The temperatures required for steam reforming are very high. The reaction is highly endothermic. Reactor designs are limited by heat transfer rather than reaction kinetics due to the endothermic nature of the reaction. The reactors which facilitate heat transfer tend to be large and heavy. Endothermicity of the reaction and the reactor size are the constraints for using fuel cells in automobiles (Ahmed and Krumpelt, 2001).

An alternative to steam reforming is direct catalytic partial oxidation of hydrocarbons which is an exothermic reaction. Hydrocarbons can be oxidized to syngas in presence of substoichiometric amount of oxygen. The oxygen is used in substoichiometric amount, hence the name partial oxidation. Partial oxidation reaction is faster than steam reforming. Partial oxidation can be carried out in smaller reactors, unlike steam reforming where reactor size increases due to heat transfer limitations (Pena et al., 1996).

The direct-oxidation reaction is difficult to study because it involves feeding of hydrocarbon and oxygen (or air) mixtures. These mixtures are explosive and proper care should be taken so that the inlet composition does not fall into explosive limits. Partial oxidation is carried out under reducing conditions. This can lead to carbon deposition 
over the catalyst surface. One solution to this problem is co-feeding of small quantities of water along with hydrocarbon and oxygen (or air) (Pena et al., 1996).

\subsection{Significance of Autothermal Reforming}

Autothermal reforming is a combination of oxidation and steam reforming reactions. Autothermal reforming was developed by Haldor Topsoe in the late 1950s so that both the reactions can be carried out in a single reactor. If an endothermic reaction of steam reforming could be combined with an exothermic reaction in the same reaction vessel, the exothermic reaction that produces heat could be used to drive the endothermic reaction that requires heat. This can be achieved by combining the oxidation of hydrocarbon with steam reforming (Pena et al., 1996). Because both reactions (steam reforming and partial oxidation) take place simultaneously, the reactor design is much simpler than that of a conventional steam reformer. Exothermic, endothermic and thermoneutral conditions can be selected by choosing an appropriate ratio of hydrocarbon: oxygen: steam. The thermoneutral point can be defined as a point where heat of reaction is zero. Referring to Equation 1.6, it can be seen that at $\mathrm{x}=0$, the reaction is endothermic. The reaction becomes less endothermic with increase in oxygen. It becomes thermoneutral at $\mathrm{x}=252.77 / 571.13=0.44$. Above this point, the reaction is exothermic. Addition of steam is also effective in suppressing deposition of carbon.

\subsection{Statement of Problem and Objectives}

The basic purpose of this research is to investigate platinum metal catalysts for partial oxidation of propane to produce hydrogen. Propane is used as a model compound for gasoline. The results obtained over propane feed can be extended to develop an onboard gasoline fuel processor. 
Some of the initial objectives of this project were to test commercial catalyst $\mathrm{Pt} / \mathrm{Al}_{2} \mathrm{O}_{3}$ obtained from Pressure Chemicals for partial oxidation of propane. Studies also included preparation of $\mathrm{Pt} / \mathrm{CeO}_{2}$ catalyst in-house and testing of its activity in the testing unit.

The main objectives include:

1. To study effect of support on partial oxidation of propane. Three $\mathrm{Pt} / \mathrm{CeO}_{2}$ catalysts having different surface area ceria supports are investigated for partial oxidation. The results obtained are also compared with $\mathrm{Pt} / \mathrm{Al}_{2} \mathrm{O}_{3}$ catalyst.

2. In order to study support effects, catalyst activity is studied for different feed ratios $\left(\mathrm{O}_{2} / \mathrm{C}_{3} \mathrm{H}_{8}\right)$ and temperatures. Characterization studies such as BET surface area and hydrogen chemisorption are also performed to understand properties of the catalysts.

3. Effect of space velocity is studied to explain the reaction scheme. 


\section{Chapter 2: Literature Review}

\subsection{Thermodynamics of Propane Oxidation}

There are several different reactions of propane with oxygen (Huff et al., 1994). They are as follows:

- Propane can react with $\mathrm{O}_{2}$ to form total oxidation products.

$$
\mathrm{C}_{3} \mathrm{H}_{8}+5 \mathrm{O}_{2} \rightarrow 3 \mathrm{CO}_{2}+4 \mathrm{H}_{2} \mathrm{O} \quad \Delta \mathrm{H}_{298}^{0}=-2043 \mathrm{~kJ} / \mathrm{mol} \quad \text { Equation } 2.1
$$

- Propane can react with substoichiometric amount of oxygen to form syngas.

$$
\mathrm{C}_{3} \mathrm{H}_{8}+\frac{3}{2} \mathrm{O}_{2} \rightarrow 3 \mathrm{CO}+4 \mathrm{H}_{2} \quad \Delta H_{298}^{0}=-227 \mathrm{~kJ} / \mathrm{mol} \quad \text { Equation } 2.2
$$

- Propane may dehydrogenate oxidatively to form propene.

$$
\mathrm{C}_{3} \mathrm{H}_{8}+\frac{1}{2} \mathrm{O}_{2} \rightarrow \mathrm{C}_{3} \mathrm{H}_{6}+\mathrm{H}_{2} \mathrm{O} \quad \Delta \mathrm{H}_{298}^{0}=-117 \mathrm{~kJ} / \mathrm{mol} \quad \text { Equation } 2.3
$$

- Propane can dehydrogenate thermally to form propene.

$$
\mathrm{C}_{3} \mathrm{H}_{8} \rightarrow \mathrm{C}_{3} \mathrm{H}_{6}+\mathrm{H}_{2} \quad \Delta H_{298}^{0}=124 \mathrm{~kJ} / \mathrm{mol}
$$

Equation 2.4

- Cracking of propane can take place to form ethylene and methane.

$$
\begin{array}{lll}
\mathrm{C}_{3} \mathrm{H}_{8} \rightarrow \mathrm{C}_{2} \mathrm{H}_{4}+\mathrm{CH}_{4} \quad \Delta H_{298}^{0}=83 \mathrm{~kJ} / \mathrm{mol} & \text { Equation } 2.5
\end{array}
$$

Some of the propane can react with water (formed from total oxidation) by steam reforming, Equation 1.1. The product mixture from combining steam reforming with propane oxidation will be affected by the water-gas-shift reaction, which occurs over many catalysts. This reaction increases the hydrogen concentration in the products at the expense of $\mathrm{CO}$.

Water gas shift:

$$
\mathrm{CO}+\mathrm{H}_{2} \mathrm{O} \rightarrow \mathrm{CO}_{2}+\mathrm{H}_{2} \quad \Delta \mathrm{H}_{298}^{0}=-41.2 \mathrm{~kJ} / \mathrm{mol} \quad \text { Equation } 2.6
$$

Some of the unreacted propane can also react with carbon dioxide formed from total oxidation through dry reforming to form syngas. 


$$
\mathrm{C}_{3} \mathrm{H}_{8}+3 \mathrm{CO}_{2} \rightarrow 6 \mathrm{CO}+4 \mathrm{H}_{2}
$$

Equation 2.7

Carbon dioxide formed from total oxidation can undergo reverse Boudouard reaction to form carbon monoxide.

$$
\mathrm{CO}_{2}+\mathrm{C} \rightarrow 2 \mathrm{CO}
$$

Equation 2.8

Huff et al. (1994) studied partial oxidation of propane on $\mathrm{Pt} / \mathrm{Al}_{2} \mathrm{O}_{3}$ foam monolith. The results indicate that, below $4 \%$ propane in air, the primary products are $\mathrm{CO}_{2}$ and $\mathrm{H}_{2} \mathrm{O}$. Between 4 and $12 \%$ propane in air, $\mathrm{CO}$ and $\mathrm{H}_{2}$ are produced. At high temperatures (above $1250 \mathrm{~K}$ ) propane can produce methane, which can be shown as follows:

$$
\begin{array}{ll}
\mathrm{C}_{3} \mathrm{H}_{8} \rightarrow 2 \mathrm{CH}_{4}+\mathrm{C} & \text { Equation } 2.9
\end{array}
$$

A selective catalytic material must be used to favor oxidation of propane to carbon monoxide and hydrogen.

\subsection{Study of Catalyst Activity}

This section deals with effect of catalyst preparation methods on catalyst performance and studies of various catalysts for partial oxidation of propane. The importance of ceria support is also discussed.

\subsubsection{Preparation}

The incipient wetness impregnation technique is commonly used for preparation of metal supported catalysts. Jovanovic and Stankovic (1987) investigated an improved impregnation technology in which catalysts were prepared using single and multiple immersions of supports in different concentrations of $\mathrm{Ni}\left(\mathrm{NO}_{3}\right)_{2}$ solutions. After the impregnation, catalyst samples were dried, calcined and then reduced. The catalyst prepared from the most concentrated solution exhibited the largest surface area. The highest selectivity for the reaction was obtained when the catalyst was prepared by 6 -fold immersion in the least concentrated solution of $\mathrm{Ni}\left(\mathrm{NO}_{3}\right)_{2}$. Stankovic and Jovanovic 
(1997) studied the performance of magnesia-supported nickel catalyst prepared under different impregnation conditions. It was observed that selectivity towards syngas formation decreases in the order $\mathrm{Al}_{2} \mathrm{O}_{3}>\mathrm{MgO}>\mathrm{CaO}$, where $\mathrm{Al}_{2} \mathrm{O}_{3}, \mathrm{MgO}$ and $\mathrm{CaO}$ are used as promoters.

Pantu and Gavalas (2002) prepared the ceria support using the citrate complexation technique for studying partial oxidation of methane on $\mathrm{Pt} / \mathrm{CeO}_{2}$. The ceria supported Pt catalyst was prepared using homogeneous precipitation method. The BET surface area of the catalyst obtained was $40 \mathrm{~m}^{2} / \mathrm{g}$ and the Pt dispersion was $69 \%$.

Pino et al. (2002) prepared the $\mathrm{Pt} / \mathrm{CeO}_{2}$ catalysts by novel solution-combustion method to study partial oxidation of methane. The hydrogen selectivity obtained was as high as $99 \%$ at $800-900{ }^{\circ} \mathrm{C}$. The $2 \% \mathrm{Pt} / \mathrm{CeO}_{2}$ catalyst does not show any carbon deposition even after extended reaction of methane with air.

Pino et al. (2003) prepared the $\mathrm{Pt} / \mathrm{CeO}_{2}$ catalysts using coprecipitation, impregnation and combustion method. The methane conversion was between $80 \%$ and $96 \%$ with hydrogen selectivity between $90 \%$ and $98 \%$. The catalyst prepared using combustion method showed the best performance for the reaction among all the ceriasupported Pt catalysts.

\subsubsection{Activity}

Pena et al. (1996) have shown that the Group VIII metals (Rh, Ni, Pt, Pd,) are active for partial oxidation of methane. Various metal-supported catalysts have been studied for autothermal reforming of methane (Ayabe et al., 2003). The sequence of the activity is: $\mathrm{Rh}>\mathrm{Pd}>\mathrm{Ni}>\mathrm{Pt}>\mathrm{Co}$. However, for propane oxidation (Maillet et al., 1996), the sequence of the activity is: $\mathrm{Pt}>\mathrm{Pd}>\mathrm{Rh}$, which is reverse of that observed by Ayabe et al., (2003) for autothermal reforming of methane. The sequence of the activity of metals for steam reforming (corresponding to the reaction of water with unreacted propane after the oxygen is completely consumed) for propane is: $\mathrm{Rh}>\mathrm{Pd}>\mathrm{Pt}$. Huff $e t$ 
al. (1994) observed that the reaction over Pd behaves similarly to that over Pt; however, Pd catalyst is deactivated due to carbon deposition.

\subsubsection{Effect of Catalyst System}

Liu et al. (2001) observed that the nature of the oxide support for the catalyst has a significant effect on its activity due to the varying active surface area. Table 2.1 gives an idea about the effect of supports on catalytic activity. The values of parameters (temperature, $\mathrm{O}_{2} / \mathrm{C}_{3} \mathrm{H}_{8}, \mathrm{X}_{\mathrm{C} 3 \mathrm{H} 8}$ ), where maximum selectivity for hydrogen is obtained are listed in the table.

For $\mathrm{Rh} /$ Fecralloy reactor (Fecralloy contains $72.6 \% \mathrm{Fe}, 22 \% \mathrm{Cr}$ and $4.8 \% \mathrm{Al}$ ), where $\mathrm{Rh}$ is deposited on Fecralloy, addition of steam increases the hydrogen production and hydrogen selectivity of more than $70 \%$ is obtained (Gjervan et al., 2003). Studies done by Barbier et al. (1992) show that there is a higher production of hydrogen with Rh and PtRh catalysts than with pure Pt.

The partial oxidation of propane to syngas over $\mathrm{NiO} / \mathrm{Al}_{2} \mathrm{O}_{3}, \mathrm{NiO} / \mathrm{MgO}$ and $\mathrm{NiO} / \mathrm{SiO}_{2}$ has been compared (Liu et al., 2001). The propane conversion and hydrogen selectivity is much lower in the presence of $\mathrm{NiO} / \mathrm{MgO}$ and $\mathrm{NiO} / \mathrm{SiO}_{2}$ catalysts than with $\mathrm{NiO} / \mathrm{Al}_{2} \mathrm{O}_{3}$ catalyst.

Also, a large difference in the activities of the catalysts is seen when $\mathrm{Fe}$ or $\mathrm{Co}$ displaces the $\mathrm{Ni}$ component in $\mathrm{LiNiLaO} / \mathrm{Al}_{2} \mathrm{O}_{3}$ catalyst. Propane conversion and hydrogen selectivity of the Fe-or-Co containing catalysts are much lower than those of 
Table 2.1 Compilation of various catalyst systems investigated for partial oxidation and autothermal reforming (S/C-Steam to carbon ratio; $\mathrm{X}_{\mathrm{C} 3 \mathrm{H}^{-}}$Conversion of Propane)

\begin{tabular}{|c|c|c|c|c|c|c|}
\hline Catalyst System & $\begin{array}{c}\text { Metal } \\
\text { Loading }\end{array}$ & $\begin{array}{c}\text { Temperature } \\
\left({ }^{\circ} \mathrm{C}\right)\end{array}$ & $\mathbf{O}_{2} / \mathbf{C}_{3} \mathbf{H}_{8}$ & $\mathrm{~S} / \mathrm{C}$ & $\begin{array}{c}\mathbf{X}_{\mathrm{C3H} 8} \\
(\%)\end{array}$ & Reference \\
\hline $\mathrm{Ni} / \mathrm{Al}_{2} \mathrm{O}_{3}$ & 10 & 800 & 0.5 & 1.5 & 100 & Ayabe et al. (2003) \\
\hline $\begin{array}{l}\mathrm{Rh} / \text { Fecralloy } \\
\text { reactor }^{* *}\end{array}$ & - & $900-1000$ & 1.9 & 0 & 100 & Gjervan et al. (2003) \\
\hline $\begin{array}{l}\mathrm{Rh} / \text { Fecralloy } \\
\text { reactor }\end{array}$ & - & 960 & 1.9 & 0.7 & 100 & Gjervan et al. (2003) \\
\hline $\mathrm{Pt} / \mathrm{Rh} / \mathrm{CeO}_{2} / \mathrm{Al}_{2} \mathrm{O}_{3}$ & $\begin{array}{l}1 \% \mathrm{Pt} \text { and } \\
0.2 \% \mathrm{Rh}\end{array}$ & 500 & 2 & 0 & 100 & $\begin{array}{c}\text { Barbier and Duprez } \\
\text { (1992) }\end{array}$ \\
\hline $\mathrm{Pt} / \mathrm{CeO}_{2} / \mathrm{Al}_{2} \mathrm{O}_{3}$ & 1 & 500 & 2 & 0 & 70 & Barbier and Duprez (1992) \\
\hline $\mathrm{Rh} / \mathrm{CeO}_{2} / \mathrm{Al}_{2} \mathrm{O}_{3}$ & 0.2 & 500 & 2 & 0 & 90 & Barbier and Duprez (1992) \\
\hline $\mathrm{Pd} / \mathrm{Al}_{2} \mathrm{O}_{3}$ & 1 & 600 & 2 & 0 & 100 & Maillet et al. (1996) \\
\hline $\mathrm{Pd} / \mathrm{Al}_{2} \mathrm{O}_{3}$ & 1 & 400 & 5 & $*$ & 96 & Maillet et al. (1996) \\
\hline $\mathrm{Pd} / \mathrm{Al}_{2} \mathrm{O}_{3}$ & 1 & 500 & 2 & $*$ & 96 & Maillet et al. (1996) \\
\hline $\mathrm{Pt} / \mathrm{Al}_{2} \mathrm{O}_{3}$ & - & 650 & 2.1 & 0 & 87.3 & Ma et al. (1996) \\
\hline $\mathrm{LiNiLaO} / \mathrm{Al}_{2} \mathrm{O}_{3}$ & - & 600 & 1.65 & 0 & 100 & Liu et al. (2001) \\
\hline $\mathrm{NiO} / \mathrm{Al}_{2} \mathrm{O}_{3}$ & - & 600 & 1.65 & 0 & 100 & Liu et al. (2001) \\
\hline $\mathrm{NiO} / \mathrm{MgO}$ & - & 600 & 1.65 & 0 & 41.3 & Liu et al. (2001) \\
\hline $\mathrm{NiO} / \mathrm{SiO}_{2}$ & - & 600 & 1.65 & 0 & 5.8 & Liu et al. (2001) \\
\hline $\mathrm{LiCoLaO} / \mathrm{Al}_{2} \mathrm{O}_{3}$ & - & 600 & 1.65 & 0 & 57.1 & Liu et al. (2001) \\
\hline $\mathrm{LiFeLaO} / \mathrm{Al}_{2} \mathrm{O}_{3}$ & - & 600 & 1.65 & 0 & 35.4 & Liu et al. (2001) \\
\hline $\mathrm{NaNiLaO} / \mathrm{Al}_{2} \mathrm{O}_{3}$ & - & 600 & 1.65 & 0 & 100 & Liu et al. (2001) \\
\hline $\mathrm{KNiLaO} / \mathrm{Al}_{2} \mathrm{O}_{3}$ & - & 600 & 1.65 & 0 & 100 & Liu et al. (2001) \\
\hline $\mathrm{LiNiCeO} / \mathrm{Al}_{2} \mathrm{O}_{3}$ & - & 600 & 1.65 & 0 & 100 & Liu et al. (2001) \\
\hline $\mathrm{LiNiYO} / \mathrm{Al}_{2} \mathrm{O}_{3}$ & - & 600 & 1.65 & 0 & 100 & Liu et al. (2001) \\
\hline $\mathrm{LiNiSmO} / \mathrm{Al}_{2} \mathrm{O}_{3}$ & - & 600 & 1.65 & 0 & 100 & Liu et al. (2001) \\
\hline $\begin{array}{l}\mathrm{Pt} / \mathrm{Al}_{2} \mathrm{O}_{3} \text { foam } \\
\text { monolith }\end{array}$ & 4.3 & $800-1200$ & 2.1 & 0 & 100 & Huff et al. (1994) \\
\hline $\mathrm{Pd} / \mathrm{Al}_{2} \mathrm{O}_{3}$ & 1 & 600 & 2.5 & 0 & 70 & Guimaraes et al. (2003) \\
\hline $\mathrm{Pd} / \mathrm{CeO}_{2} / \mathrm{Al}_{2} \mathrm{O}_{3}$ & 1 & 600 & 2.5 & 0 & 90 & Guimaraes et al. (2003) \\
\hline
\end{tabular}

*Amount of steam added is not given

** See the text for composition of Fecralloy 
the Ni-containing catalyst. The $\mathrm{NiO} / \mathrm{Al}_{2} \mathrm{O}_{3}$ catalyst and catalysts with different alkali metal oxides $\mathrm{ALaNiO} / \mathrm{Al}_{2} \mathrm{O}_{3}(\mathrm{~A}=\mathrm{Li}, \mathrm{Na}, \mathrm{K})$ and rare earth metal oxides $\mathrm{LiBNiO} / \mathrm{Al}_{2} \mathrm{O}_{3}$ $(\mathrm{B}=\mathrm{La}, \mathrm{Sm}, \mathrm{Y}, \mathrm{Ce})$ shows almost the same performance. Propane is converted completely. The selectivity of $\mathrm{CO}$ and hydrogen remain at about $45 \%$ and $85 \%$ respectively. Also it can be seen that modification of the $\mathrm{NiO} / \mathrm{Al}_{2} \mathrm{O}_{3}$ catalyst with alkali and rare-earth metal oxides does not show a significant effect on the reaction performance of the partial oxidation of propane reaction (Liu et al., 2001).

Studies done by Guimaraes et al. (2003) show that $\mathrm{Pd} / \mathrm{CeO}_{2} / \mathrm{Al}_{2} \mathrm{O}_{3}$ catalyst is less active than the $\mathrm{Pd} / \mathrm{Al}_{2} \mathrm{O}_{3}$ catalyst at low temperatures but becomes more than $\mathrm{Pd} / \mathrm{Al}_{2} \mathrm{O}_{3}$ catalyst at high temperatures.

\subsubsection{Ceria Support}

Cerium oxide has been used in three-way catalysts used for automotive emission control. In these catalysts, cerium oxide acts as oxygen-storage component. Cerium oxide shows an easy transition between $\mathrm{Ce}^{4+}$ and $\mathrm{Ce}^{3+}$ and so can store large amounts of $\mathrm{O}_{2}$. This property is very useful in catalysis especially in oxidation reactions and also in promoting number of catalytic reactions on noble metal particles including water gas shift reaction. Ceria promotes stabilization of precious metals and prevents sintering of particles (Guimaraes et al., 2003).

According to Pantu and Gavalas (2002), noble metals when supported on ceria show much higher rates for water gas shift, steam reforming and carbon dioxide reforming of methane than when supported on silica or alumina. These reactions exhibit a bifunctional mechanism, in which oxygen from cerium oxide reacts with carbon compounds adsorbed on the noble metal, while the partially reduced cerium oxide reacts with gaseous oxidant and gets reoxidized. Methane partial oxidation was studied over $\mathrm{Pt} / \mathrm{CeO}_{2}$ catalysts. Higher conversions and selectivities were obtained at lower temperatures. This is happening possibly because of the oxidation of adsorbed methane 
by oxygen from cerium oxide and then reoxidation of partially reduced cerium oxide by $\mathrm{CO}_{2}$ and $\mathrm{H}_{2} \mathrm{O}$.

Studies done by Diwell et al. (1991) to test the catalyst activity in a simulated exhaust environment show that ceria maintains the Pt metal in an oxidized state, thus stabilizing Pt dispersion. This effect is unfavourable for catalytic activity under oxidizing conditions, but under reducing conditions, ceria promotes the reduction of platinum oxide, thus improving activity of the catalyst for water gas shift, steam reforming and NO reduction. The presence of ceria support in the three way catalysts promotes stabilization of precious metals such as $\mathrm{Pt}$ and $\mathrm{Rh}$. In case of $\mathrm{Pt} / \mathrm{Al}_{2} \mathrm{O}_{3}$ catalyst, substantial sintering of Pt occurs at high temperature but addition of $\mathrm{CeO}_{2}$ results in stabilization of $\mathrm{Pt}$ dispersion, as a result of strong $\mathrm{Pt}-\mathrm{CeO}_{2}$ interaction. Alumina supported $\mathrm{Rh}$ catalyst shows thermal deactivation as a result of detrimental $\mathrm{Rh}-\mathrm{Al}_{2} \mathrm{O}_{3}$ interaction at grain boundaries. Addition of $\mathrm{CeO}_{2}$ improves thermal stability of $\mathrm{Rh}$ significantly.

Steam reforming can be used to lower the hydrocarbon emissions under oxygen deficient conditions. The carbon monoxide in the products can be removed by water gas shift reaction. Addition of ceria in three way catalysts containing Pt-Rh promotes the steam reforming reaction.

Golunski et al. (1995) studied Temperature Programmed Reduction (TPR) of ceria supports and ceria supported Pt catalyst. Ceria shows two peaks at $450^{\circ} \mathrm{C}$ and $850^{\circ}$ C. The first peak is due to surface reduction and the second peak is due to bulk reduction of ceria. After impregnating Pt on ceria, the first peak shifts to $120-250{ }^{\circ} \mathrm{C}$. This is due to interaction between Pt and ceria.

Otsuka et al. (1997) observed that cerium oxide could partially oxidize methane to syngas in absence of oxygen. Addition of platinum metal to cerium oxide increased the rate of oxidation to Syngas. 


\subsection{Effect of $\mathrm{O}_{2} / \mathrm{C}_{3} \mathrm{H}_{8}$ Ratio}

The $\mathrm{O}_{2} / \mathrm{C}_{3} \mathrm{H}_{8}$ ratio has a significant effect on propane conversion and hydrogen selectivity. According to Huff et al. (1994), the stoichiometric $\mathrm{O}_{2} / \mathrm{C}_{3} \mathrm{H}_{8}\left(\mathrm{O}_{2} / \mathrm{C}_{3} \mathrm{H}_{8}=5\right)$ ratio gives carbon dioxide. Substoichiometric ratios give syngas. The $\mathrm{O}_{2} / \mathrm{C}_{3} \mathrm{H}_{8}$ ratio is 1.89 for highest selectivity of hydrogen on $\mathrm{Pt} / \alpha-\mathrm{Al}_{2} \mathrm{O}_{3}$ foam monolith. The ratio is 1.25 for $\mathrm{LiLaNiO} / \gamma-\mathrm{Al}_{2} \mathrm{O}_{3}$ (Liu et al., 2001).

\subsection{Effect of Steam Addition}

Studies done by Ayabe et al. (2003) show that addition of steam has a significant effect on carbon deposition. Carbon deposition is more significant for higher hydrocarbons. Addition of steam lowers carbon deposition. Hydrogen concentration in the product gases increases with increase in steam/carbon (S/C) ratio. Addition of steam decreases the load on total oxidation of hydrocarbon and increases the amount of hydrocarbon made available for steam reforming. Table 2.2 and Table 2.3 show effect of $\mathrm{S} / \mathrm{C}$ ratio. It is seen that as the $\mathrm{S} / \mathrm{C}$ ratio increases, the amount of hydrogen produced increases.

Table 2.2 Effect of $\mathrm{S} / \mathrm{C}$ ratio on autothermal reforming of propane

\begin{tabular}{|c|c|c|c|c|c|}
\hline $\begin{array}{l}\text { Catalyst } \\
\text { system }\end{array}$ & $\begin{array}{c}\text { Temperature } \\
\left({ }^{\circ} \mathrm{C}\right)\end{array}$ & $\mathrm{S} / \mathrm{C}$ & $\mathbf{O}_{2} / \mathbf{C}_{3} \mathbf{H}_{8}$ & $\begin{array}{c}\mathbf{H}_{2} \\
(\mathrm{~mol} \%)\end{array}$ & Reference \\
\hline $\begin{array}{l}\text { Platinum coated } \\
\text { honeycomb }\end{array}$ & 700 & 0.55 & 2.1 & 24 & Rampe et al. (2000) \\
\hline $\begin{array}{l}\text { Platinum coated } \\
\text { honeycomb }\end{array}$ & 700 & 1.4 & 2.1 & 27 & Rampe et al. (2000) \\
\hline $\mathrm{Ni} / \mathrm{Al}_{2} \mathrm{O}_{3}$ & 600 & 0 & 0.5 & 12 & Ayabe et al. (2003) \\
\hline $\mathrm{Ni} / \mathrm{Al}_{2} \mathrm{O}_{3}$ & 600 & 0.5 & 0.5 & 30 & Ayabe et al. (2003) \\
\hline $\mathrm{Ni} / \mathrm{Al}_{2} \mathrm{O}_{3}$ & 600 & 1.0 & 0.5 & 39 & Ayabe et al. (2003) \\
\hline $\mathrm{Ni} / \mathrm{Al}_{2} \mathrm{O}_{3}$ & 600 & 1.5 & 0.5 & 49 & Ayabe et al. (2003) \\
\hline $\begin{array}{l}\mathrm{Rh} / \text { Fecralloy } \\
\text { reactor }\end{array}$ & 1000 & 0 & 1.9 & 18 & $\begin{array}{c}\text { Gjervan et al. } \\
(2003)\end{array}$ \\
\hline $\begin{array}{l}\mathrm{Rh} / \text { Fecralloy } \\
\text { reactor }\end{array}$ & 1000 & 0.7 & 1.9 & 23 & $\begin{array}{c}\text { Gjervan et al. } \\
\text { (2003) }\end{array}$ \\
\hline
\end{tabular}


Table 2.3 Effect of S/C ratio on autothermal reforming of propane (Guimaraes $e t$ al., 2003)

\begin{tabular}{|c|c|c|c|c|}
\hline Catalyst system & $\begin{array}{c}\text { Temperature } \\
\left({ }^{\mathbf{}} \mathbf{C}\right)\end{array}$ & $\mathbf{S} / \mathbf{C}$ & $\mathbf{O}_{2} / \mathbf{C}_{\mathbf{3}} \mathbf{H}_{\mathbf{8}}$ & $\mathbf{H}_{\mathbf{2}}$ (mol \%) \\
\hline $\mathrm{Pd} / \mathrm{Al}_{2} \mathrm{O}_{3}$ & 600 & 0 & 2.5 & 1.25 \\
\hline $\mathrm{Pd} / \mathrm{Al}_{2} \mathrm{O}_{3}$ & 600 & 1 & 2.5 & 1.4 \\
\hline $\mathrm{Pd} / \mathrm{CeO}_{2} / \mathrm{Al}_{2} \mathrm{O}_{3}$ & 600 & 0 & 2.5 & 0.9 \\
\hline $\mathrm{Pd} / \mathrm{CeO}_{2} / \mathrm{Al}_{2} \mathrm{O}_{3}$ & 600 & 1 & 2.5 & 3.0 \\
\hline
\end{tabular}

\subsection{Mechanism and Kinetics}

According to Maillet et al. (1996), there are two discrete zones for partial oxidation of propane. In the first zone (below $400{ }^{\circ} \mathrm{C}$ ), the complete oxidation of propane (Equation 2.1) takes place, producing $\mathrm{CO}_{2}$ and $\mathrm{H}_{2} \mathrm{O}$. In the second zone (above $400{ }^{\circ} \mathrm{C}$ ), the remaining propane reacts with water by steam reforming (Equations 2.10 and 2.11).

$$
\begin{aligned}
& \mathrm{C}_{3} \mathrm{H}_{8}+3 \mathrm{H}_{2} \mathrm{O} \rightarrow 3 \mathrm{CO}+7 \mathrm{H}_{2} \\
& \mathrm{C}_{3} \mathrm{H}_{8}+6 \mathrm{H}_{2} \mathrm{O} \rightarrow 3 \mathrm{CO}_{2}+10 \mathrm{H}_{2}
\end{aligned}
$$

Passos et al. (2003) has studied partial oxidation of methane on $\mathrm{Pt} / \mathrm{Y}_{2} \mathrm{O}_{3}, \mathrm{Pt} / \mathrm{Al}_{2} \mathrm{O}_{3}$ and $\mathrm{Pt} / \mathrm{CeO}_{2}$ catalysts. $\mathrm{Pt} / \mathrm{Al}_{2} \mathrm{O}_{3}$ and $\mathrm{Pt} / \mathrm{CeO}_{2}$ catalysts showed indirect mechanism consisting two steps: In the first step methane undergoes total oxidation and in the second step unreacted methane undergoes steam and dry reforming, while $\mathrm{Pt} / \mathrm{Y}_{2} \mathrm{O}_{3}$ showed direct partial oxidation. No steam reforming was observed for $\mathrm{Pt} / \mathrm{Y}_{2} \mathrm{O}_{3}$ catalyst while dry reforming was observed at high temperatures.

Ma et al. (1996) has studied the reaction kinetics for propane oxidation on $\mathrm{Pt} / \delta$ $\mathrm{Al}_{2} \mathrm{O}_{3}$. The rate expressions were approximated by the power law equation:

$$
r=k\left[C_{3} H_{8}\right]^{a}\left[O_{2}\right]^{b}
$$

The parameters of the power law Equation 2.12 are given in Table 2.4. 
Table 2.4 Parameters of the power law Equation 2.12

\begin{tabular}{|c|c|c|c|c|c|}
\hline Catalyst & $\mathbf{T}(\mathbf{K})$ & $\mathbf{k}\left(\mathbf{m o l} / \mathbf{m}^{2} \mathbf{h} \mathbf{~ k P a}{ }^{(\mathbf{a}+\mathbf{b})}\right)$ & $\mathbf{E}(\mathbf{k J} / \mathbf{m o l})$ & $\mathbf{a}$ & $\mathbf{b}$ \\
\hline $\mathrm{P} t / \delta-\mathrm{Al}_{2} \mathrm{O}_{3}$ & $423-463$ & $1.87 \times 10^{9}$ & $104.7 \pm 1$ & $1.1 \pm 0.05$ & $-0.6 \pm 0.1$ \\
\hline
\end{tabular}

\subsection{Dry reforming}

Pantu and Gavalas (2002) studied partial oxidation and dry reforming of methane on $0.5 \% \mathrm{Pt} / \mathrm{CeO}_{2}$ and $0.5 \% \mathrm{Pt} / \mathrm{Al}_{2} \mathrm{O}_{3}$ catalysts. The $\mathrm{CO}_{2} / \mathrm{CH}_{4}=1$ was used for dry reforming of methane. They observed that on $\mathrm{Pt} / \mathrm{CeO}_{2}$, steam reforming of methane is faster than reforming with $\mathrm{CO}_{2}$. Also dry reforming on $\mathrm{Pt} / \mathrm{CeO}_{2}$ was two times faster than on $\mathrm{Pt} / \mathrm{Al}_{2} \mathrm{O}_{3}$ at $600{ }^{\circ} \mathrm{C}$. Methane conversion was $56 \%$ at $600{ }^{\circ} \mathrm{C}$ over $0.5 \% \mathrm{Pt} / \mathrm{CeO}_{2}$. Both $0.5 \% \mathrm{Pt} / \mathrm{CeO}_{2}$ and $0.5 \% \mathrm{Pt} / \mathrm{Al}_{2} \mathrm{O}_{3}$ are active for dry reforming of methane. Solymosi and Tolmacsov (2002) studied dry reforming of propane over alumina supported noble metals. The conversion of propane is $5.4 \%$ over $1 \% \mathrm{Pt} / \mathrm{Al}_{2} \mathrm{O}_{3}$ catalyst at $650{ }^{\circ} \mathrm{C}$. The activities of noble metals in dry reforming decrease in the sequence $\mathrm{Ru}>\mathrm{Rh}$ $>\mathrm{Pd}>\mathrm{Pt}=\mathrm{Ir}$. The results show that $1 \% \mathrm{Pt} / \mathrm{Al}_{2} \mathrm{O}_{3}$ is a poor catalyst for dry reforming of propane.

\subsection{Water gas shift reaction}

According to Luengnaruemitchai et al. (2003), there are two types of commercial water gas shift catalysts. Oxides of iron and chromium are high temperature water gas shift catalysts and are used at $400-500{ }^{\circ} \mathrm{C}$. Low temperature shift catalysts consist of copper, zinc oxide and alumina and are used between 200 and $400{ }^{\circ} \mathrm{C}$. For water gas shift reaction, conversion is equilibrium limited at high temperatures and kinetically limited at low temperatures. $\mathrm{Pt}$ is much more active than $\mathrm{Au}$ when comparison is made between $\mathrm{Pt} / \mathrm{CeO}_{2}$ and $\mathrm{Au} / \mathrm{CeO}_{2}$ catalysts. Ceria promotes precious metal catalysts for water gas shift reaction. Hilare et al. (2001) discussed mechanism for water gas shift reaction on ceria-based catalysts. 


$$
\begin{array}{lr}
\mathrm{CO}+\mathrm{\sigma} \rightarrow \mathrm{CO}_{a d} & \text { Equation 2.13 } \\
\mathrm{H}_{2} \mathrm{O}+\mathrm{Ce}_{2} \mathrm{O}_{3} \rightarrow 2 \mathrm{CeO}_{2}+\mathrm{H}_{2} & \text { Equation 2.14 } \\
\mathrm{CO}_{a d}+2 \mathrm{CeO}_{2} \rightarrow \mathrm{CO}_{2}+\mathrm{Ce}_{2} \mathrm{O}_{3}+\sigma & \text { Equation 2.15 }
\end{array}
$$

$\mathrm{CO}$ adsorbs on transition metal site $(\sigma)$ and reacts with oxygen from ceria to form $\mathrm{CO}_{2}$. Reduced cerium oxide is reoxidized by $\mathrm{H}_{2} \mathrm{O}$. Grenoble et al. (1981) studied water gas shift reaction over group VIII metals supported on alumina and found the order of activity at $300{ }^{\circ} \mathrm{C}$ to be $\mathrm{Ru}>\mathrm{Pt}>\mathrm{Pd}>\mathrm{Rh}>\mathrm{Ir}$. The effect of support for Pt catalysts decrease in the sequence: $\mathrm{Pt} / \mathrm{Al}_{2} \mathrm{O}_{3}>\mathrm{Pt} / \mathrm{SiO}_{2}>\mathrm{Pt} / \mathrm{C}$. 


\section{Chapter 3: Experimental Set Up and Procedure}

\subsection{Equipment Description}

The flow sheet for the catalyst-testing unit is shown in Figure 3.1. The unit has three lines for gas feeds, each being independently controlled by a Brooks mass-flow controller (MFC). The gases first pass through $2 \mu \mathrm{m}$ filters (F) and then pass through the MFC. The gases then pass through a mixing vessel before passing through either the reactor or a bypass line. The pressure in the reactor system is measured by a pressure gauge $(\mathrm{P})$. The reactor consists of a stainless-steel tube $(304 \mathrm{~L})$ of outer diameter of 12.7 $\mathrm{mm}(0.5 \mathrm{inch})$ and nominal length of $0.45 \mathrm{~m}$ ( $17.5 \mathrm{inch})$, placed in a $0.33 \mathrm{~m}$ (13.25 inch) long, single-zone furnace from Applied Test Systems. The effects of flow rate and dry reforming reactions were studied in a quartz reactor having the same dimensions as stainless-steel tube reactor. Typically $0.1 \mathrm{~g}$ of catalyst is placed in the center of the reactor, with quartz chips placed upstream and downstream of the catalyst. The product gases pass through a cold trap for condensation of gases. For this research work, it was not filled with any material. The outlet of the reactor is connected to a Varian 3600 gas chromatograph $(\mathrm{GC})$ and the product gases are analyzed on-line by GC using two columns and two detectors in parallel. The Chromperfect Software is used for data acquisition and analysis. In the GC, the flow is split between the two columns: a Haysep D packed column, $6 \mathrm{~m} \times 3 \mathrm{~mm}$, and an alumina capillary column, $30 \mathrm{~m}$ long. The oven temperature is ramped from $35^{\circ} \mathrm{C}$ to $200{ }^{\circ} \mathrm{C}$. The details of the $\mathrm{GC}$ operating conditions are given in Appendix A. The packed column is connected to a thermal-conductivity detector (TCD), which provides quantitative analysis for $\mathrm{N}_{2}, \mathrm{H}_{2}, \mathrm{CO}, \mathrm{CO}_{2}, \mathrm{CH}_{4}, \mathrm{C}_{3} \mathrm{H}_{8}$ and $\mathrm{H}_{2} \mathrm{O}$. Nitrogen is the internal standard, while argon serves as the carrier gas. The capillary column is connected to a flame-ionization detector (FID), which is used to detect hydrocarbons such as $\mathrm{CH}_{4}$ and $\mathrm{C}_{3} \mathrm{H}_{8}$. The reactor system is placed in a hood. 


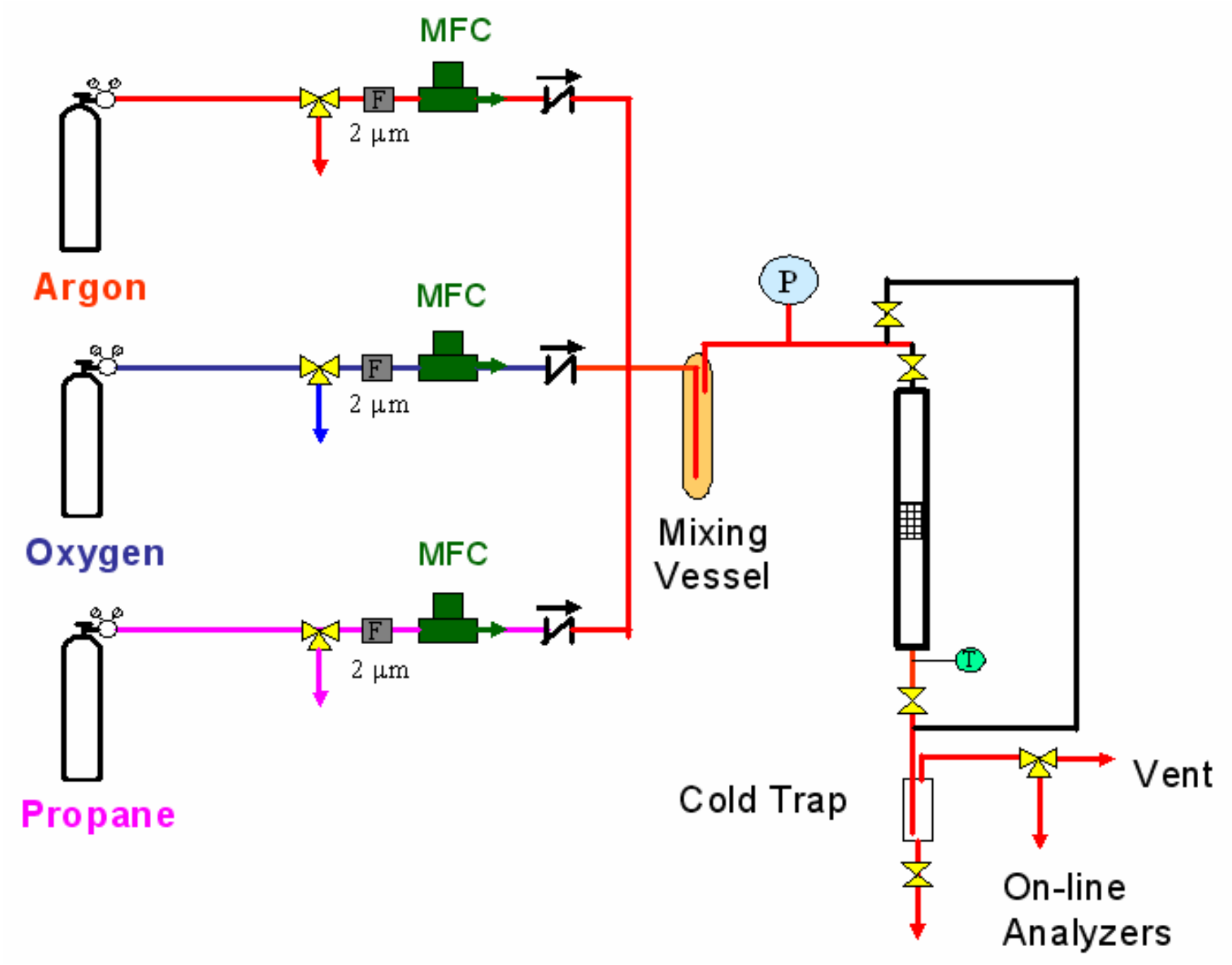

Figure 3.1 Flow sheet for Catalyst Testing Unit 


\subsection{Experimental Procedure}

This section deals with catalyst preparation methods for ceria and alumina catalysts. The reactor loading and pretreatment procedure is also discussed.

\subsubsection{Catalyst Preparation}

The commercial ceria support that was obtained from Sigma-Aldrich has a very low surface area and that is $17.3 \mathrm{~m}^{2} / \mathrm{g}$. Two high-surface-area ceria supports were prepared by homogeneous precipitation and by decomposition, as described in Sections 3.2.1.2 and 3.2.1.3. Platinum was loaded on these supports by incipient wetness method. Three types of $\mathrm{Pt} / \mathrm{CeO}_{2}$ catalysts, $\mathrm{Pt} / \mathrm{CeO}_{2}(\mathrm{~A}), \mathrm{Pt} / \mathrm{CeO}_{2}$ (B) and $\mathrm{Pt} / \mathrm{CeO}_{2}(\mathrm{C})$ are tested for partial oxidation reaction where $\mathrm{Pt} / \mathrm{CeO}_{2}(\mathrm{~A})$ corresponds to $\mathrm{Pt}$ catalyst prepared using commercial ceria, $\mathrm{Pt} / \mathrm{CeO}_{2}$ (B) corresponds to $\mathrm{Pt}$ catalyst prepared using ceria made by homogeneous method and $\mathrm{Pt} / \mathrm{CeO}_{2}$ (C) corresponds to $\mathrm{Pt}$ catalyst prepared using ceria made by decomposition method. The results obtained for the $\mathrm{Pt} / \mathrm{CeO}_{2}$ catalysts are also compared with $\mathrm{Pt} / \mathrm{Al}_{2} \mathrm{O}_{3}$ catalyst prepared as described in Section 3.2.1.4.

\subsubsection{Pt/CeO $(\mathrm{A})$}

Initially, cerium oxide (cerium (IV) oxide, powder, < 5 micron, $99.9 \%$ ) from Sigma-Aldrich was calcined at $400^{\circ} \mathrm{C}$ for $3 \mathrm{hrs}$. As mentioned above, the Pt was added inhouse by incipient wetness. The $1 \% \mathrm{Pt} / \mathrm{CeO}_{2}(\mathrm{~A})$ catalyst was prepared by impregnating 20 g ceria with $0.9 \mathrm{~g}$ of $1.12 \mathrm{M} \mathrm{H}_{2} \mathrm{PtCl}_{6}$ solution to yield a catalyst containing $1 \% \mathrm{Pt}$ (wt \%) metal. Then the impregnated support containing the catalyst was dried at $100{ }^{\circ} \mathrm{C}$ overnight. The dried catalyst was calcined at $400{ }^{\circ} \mathrm{C}$ for $3 \mathrm{hrs}$. The catalyst pellets were crushed and sieved into grains of 0.595-0.42 mm (30-40 mesh). The BET surface area of the catalyst was determined to be $9.9 \mathrm{~m}^{2} / \mathrm{g}$. Another catalyst with $0.5 \%$ metal loading was prepared using same method of preparation. 


\subsubsection{Pt/CeO $(\mathrm{B})$}

The Pt/CeO 2 (B) was prepared entirely in-house by Dr. Tapan Das of Department of Chemical Engineering, West Virginia University, with the cerium oxide prepared using precipitation. First, cerium nitrate was neutralized against ammonium hydroxide to form cerium hydroxide, which precipitated from aqueous solution. The slurry was dried, and then calcined at $400^{\circ} \mathrm{C}$ for $3 \mathrm{hrs}$ to form cerium oxide. The platinum was added by incipient wetness. The $1 \% \mathrm{Pt} / \mathrm{CeO}_{2}$ (B) catalyst was prepared by impregnating $20 \mathrm{~g}$ ceria with $3.4 \mathrm{~g}$ of $0.31 \mathrm{M} \mathrm{H}_{2} \mathrm{PtCl}_{6}$ solution to yield a catalyst containing $1 \% \mathrm{Pt}$ (wt \%) metal. Then the impregnated support containing the catalyst was dried at $100{ }^{\circ} \mathrm{C}$ overnight. The dried catalyst was calcined at $400{ }^{\circ} \mathrm{C}$ for $3 \mathrm{hrs}$. The catalyst pellets were crushed and sieved into grains of 0.841-0.595 mm (20-30 mesh). The BET surface area of the catalyst was $65.8 \mathrm{~m}^{2} / \mathrm{g}$, which is about seven times larger than that of $1 \% \mathrm{Pt} / \mathrm{CeO}_{2}(\mathrm{~A})$.

\subsubsection{Pt/CeO $(\mathrm{C})$}

The $\mathrm{Pt} / \mathrm{CeO}_{2}$ (C) was also prepared entirely in-house by Dr. Tapan Das. Now cerium oxide was prepared by decomposition of cerium nitrate through calcination under air at $500{ }^{\circ} \mathrm{C}$ for $4 \mathrm{hrs}$. The platinum was added by incipient wetness. The $1 \% \mathrm{Pt} / \mathrm{CeO}_{2}(\mathrm{C})$ catalyst was prepared by impregnating $20 \mathrm{~g}$ ceria with $3.9 \mathrm{~g}$ of $0.26 \mathrm{M} \mathrm{H}_{2} \mathrm{PtCl}_{6}$ solution to yield a catalyst containing $1 \% \mathrm{Pt}(\mathrm{wt} \%$ ) metal. Then the impregnated support containing the catalyst was dried at $100{ }^{\circ} \mathrm{C}$ overnight. The dried catalyst was calcined at $400{ }^{\circ} \mathrm{C}$ for 3 hrs. The catalyst pellets were crushed and sieved into grains of 0.841-0.595 mm (20-30 mesh). The BET surface area of the catalyst was determined to be $80.4 \mathrm{~m}^{2} / \mathrm{g}$, which is about eight times larger than that of $1 \% \mathrm{Pt} / \mathrm{CeO}_{2}(\mathrm{~A})$.

\subsubsection{4 $\mathrm{Pt} / \mathrm{Al}_{2} \mathrm{O}_{3}$}

The $\mathrm{Pt} / \mathrm{Al}_{2} \mathrm{O}_{3}$ catalyst was prepared using $\gamma-\mathrm{Al}_{2} \mathrm{O}_{3}$ obtained from Sasol North America. The support $\gamma-\mathrm{Al}_{2} \mathrm{O}_{3}$ is used because it is a stable phase of alumina in the reaction temperature range. The $\gamma-\mathrm{Al}_{2} \mathrm{O}_{3}$ was calcined at $400{ }^{\circ} \mathrm{C}$ for $3 \mathrm{hrs}$. The platinum 
was added by incipient wetness. The $1 \% \mathrm{Pt} / \mathrm{Al}_{2} \mathrm{O}_{3}$ catalyst was prepared by impregnating $20 \mathrm{~g} \gamma-\mathrm{Al}_{2} \mathrm{O}_{3}$ with $10.3 \mathrm{~g}$ of $0.1 \mathrm{M} \mathrm{H}_{2} \mathrm{PtCl}_{6}$ solution to yield a catalyst containing $1 \% \mathrm{Pt}$ (wt \%) metal. Then the impregnated support containing the catalyst was dried at $100{ }^{\circ} \mathrm{C}$ overnight. The dried catalyst was calcined at $400^{\circ} \mathrm{C}$ for $3 \mathrm{hrs}$. The catalyst pellets were crushed and sieved into grains of 0.841-0.595 mm (20-30 mesh). The BET surface area of the fresh catalyst is $153 \mathrm{~m}^{2} / \mathrm{g}$, which is sixteen times larger than that of $1 \% \mathrm{Pt} / \mathrm{CeO}_{2}(\mathrm{~A})$.

\subsubsection{Reactor loading}

For each run, the bottom of the reactor is first loaded with quartz chips. Then quartz wool is placed above the quartz chips. The catalyst bed consists of typically $0.1 \mathrm{~g}$ catalyst mixed with $0.5 \mathrm{~g}$ of quartz chips and it is loaded above the quartz wool. Then additional quartz wool is placed on the catalyst bed, followed by additional quartz chips. The loaded reactor is then sealed with quartz wool and mounted in a furnace. A thermocouple is adjusted so that the tip of it just touches the catalyst bed.

\subsubsection{Pretreatment and Reaction}

The catalyst pretreatment is carried out by reducing Pt catalyst with hydrogen at $400{ }^{\circ} \mathrm{C}$ for 3 hours. Thus platinum oxides are reduced to platinum metal. The GC is started only after ensuring the flow of the carrier gas through the column and the detectors. After the pretreatment, the reaction is started by adjusting the required flows of the feed gases and setting the furnace temperatures using the temperature controller. The reaction is carried out at atmospheric pressure. The sample is injected to the GC by means of the 10 port sampling valve. The sample is injected $1 \mathrm{hr}$ after the set point temperature is reached, and product analysis is carried out. The Chromperfect software is used to analyze the peaks for gases which are detected by TCD and FID. A typical analysis time is 45 minutes. 


\subsubsection{Materials and Methodology}

This section deals with procedure and reaction conditions for the experiments for studying effect of various parameters such as temperature, $\mathrm{O}_{2} / \mathrm{C}_{3} \mathrm{H}_{8}$ ratio and flow rate on partial oxidation of propane.

\subsubsection{Materials}

The catalyst pellets were made from the powdered form of a catalyst by applying 10 tons pressure on the catalyst powder. The catalyst pellets were crushed and sieved into grains of 0.841-0.595 mm (20-30 mesh). Typically $0.1 \mathrm{~g}$ of the catalyst was tested.

\subsubsection{Effect of Temperature}

Initially, the catalyst was reduced at $400{ }^{\circ} \mathrm{C}$ for $3 \mathrm{hrs}$ by passing hydrogen. The amount of catalyst used was 0.1 g. The feed ratio used was $\mathrm{C}_{3} \mathrm{H}_{8}: \mathrm{O}_{2}: \mathrm{N}_{2}: \mathrm{Ar}=$ 10.8:19.2:10.8:259 (molar ratios), with a total feed rate of $300 \mathrm{scc} / \mathrm{min}$ and $90 \%$ inert. This feed ratio correspond to $\mathrm{O}_{2} / \mathrm{C}_{3} \mathrm{H}_{8}=1.78$. This feed ratio was chosen so that the $\mathrm{O}_{2} / \mathrm{C}_{3} \mathrm{H}_{8}$ ratio does not fall in the explosive range (between $\mathrm{O}_{2} / \mathrm{C}_{3} \mathrm{H}_{8}=2$ and 10). Also the minimum oxygen concentration is $11 \%$ in the mixture of organic and inert gases. Hence $90 \%$ of inert is used in the reactant mixture to avoid explosion. The reaction was carried out at atmospheric pressure. This reaction was carried out in the stainless steel reactor.

The catalyst was tested at temperatures ranging from $300{ }^{\circ} \mathrm{C}$ to $800^{\circ} \mathrm{C}$. The reaction temperature and reactant gases flow rates were kept constant for $1 \mathrm{hr}$ at each temperature before the GC sample was taken.

\subsubsection{Study of thermal stability of supports and catalysts}

The thermal stability of the three ceria supports and the corresponding catalysts was studied under nitrogen atmosphere. The samples were placed in a tube furnace under $\mathrm{N}_{2}$ flow. Temperature was increased at the rate of $10^{\circ} \mathrm{C} / \mathrm{min}$ from room temperature to $900^{\circ}$ 
C. Then the temperature was held constant at $900{ }^{\circ} \mathrm{C}$ for $24 \mathrm{hrs}$. The BET surface areas of the fresh and heated samples were measured and compared.

\subsubsection{Study of stability of catalyst for partial oxidation of propane}

This experiment was carried out using $1 \% \mathrm{Pt} / \mathrm{CeO}_{2}(\mathrm{C})$ and $1 \% \mathrm{Pt} / \mathrm{Al}_{2} \mathrm{O}_{3}$ catalysts. Initially, the catalyst was reduced at $400{ }^{\circ} \mathrm{C}$ for $3 \mathrm{hrs}$ in $\mathrm{H}_{2}$ flow. The amount of catalyst used was $0.1 \mathrm{~g}$. The total flow rate was $300 \mathrm{scc} / \mathrm{min}$ with $90 \%$ inert. This reaction was carried out at $800{ }^{\circ} \mathrm{C}$ for $1 \% \mathrm{Pt} / \mathrm{CeO}_{2}(\mathrm{C})$ and at $600{ }^{\circ} \mathrm{C}$ for $1 \% \mathrm{Pt} / \mathrm{Al}_{2} \mathrm{O}_{3}$ catalyst. The ratio of $\mathrm{O}_{2} / \mathrm{C}_{3} \mathrm{H}_{8}$ was 1.78 . The stability of the catalyst was studied for 15 hours on stream.

\subsubsection{Effect of $\mathrm{O}_{2} / \mathrm{C}_{3} \mathrm{H}_{8}$ ratio}

This experiment was carried out in the stainless steel reactor using $1 \% \mathrm{Pt} / \mathrm{CeO}_{2}(\mathrm{C})$ and $1 \% \mathrm{Pt} / \mathrm{Al}_{2} \mathrm{O}_{3}$ catalyst. Initially, the catalyst was reduced at $400^{\circ} \mathrm{C}$ for $3 \mathrm{hrs} \mathrm{in} \mathrm{H}_{2}$ flow. The amount of catalyst used was $0.1 \mathrm{~g}$. The total flow rate was $300 \mathrm{scc} / \mathrm{min}$ with $90 \%$ inert. This reaction was carried out at $675{ }^{\circ} \mathrm{C}$ and atmospheric pressure. The ratio of $\mathrm{O}_{2} / \mathrm{C}_{3} \mathrm{H}_{8}$ was varied from 0.5 to 8 . It was increased in increments of 0.5 up to $\mathrm{O}_{2} / \mathrm{C}_{3} \mathrm{H}_{8}=5$ and in increment of 1 thereafter. The ratio of $\mathrm{O}_{2} / \mathrm{C}_{3} \mathrm{H}_{8}$ for total combustion is 5 and that for partial oxidation is 1.5 .

\subsubsection{Study of ceria and alumina support}

Partial oxidation of propane was studied for $\mathrm{CeO}_{2}(\mathrm{C})$ and $\gamma-\mathrm{Al}_{2} \mathrm{O}_{3}$ supports. The support was used in powder form. The amount of support used was $0.02 \mathrm{~g}$. The support was diluted with $0.1 \mathrm{~g}$ of quartz chips. The support was initially activated at $350^{\circ} \mathrm{C}$ for 2 hrs in Ar flow. Then it was reduced at $400^{\circ} \mathrm{C}$ for $3 \mathrm{hrs}$ in $\mathrm{H}_{2}$ flow. The reaction was carried out at $600{ }^{\circ} \mathrm{C}$. It was studied at $50 \mathrm{scc} / \mathrm{min}$ and $300 \mathrm{scc} / \mathrm{min}$ total flow rates containing 90 $\%$ inert. The $\mathrm{O}_{2} / \mathrm{C}_{3} \mathrm{H}_{8}$ ratio was 1.78 . 


\subsubsection{Effect of flow rate}

Effect of flow was studied for $0.01 \mathrm{~g}$ and $0.02 \mathrm{~g}$ amount of $1 \% \mathrm{Pt} / \mathrm{CeO}_{2}(\mathrm{C})$ and 1 $\% \mathrm{Pt} / \mathrm{Al}_{2} \mathrm{O}_{3}$ catalysts. The reaction was carried out in the quartz reactor at $600{ }^{\circ} \mathrm{C}$ and atmospheric pressure. This reaction temperature was chosen so that a low conversion of propane is obtained. This reaction temperature and small amount of catalysts $(0.01 \mathrm{~g}$ and $0.02 \mathrm{~g}$ ) were chosen so that the reactor can be studied as a differential reactor.

Initially, $0.01 \mathrm{~g}$ of $1 \% \mathrm{Pt} / \mathrm{CeO}_{2}(\mathrm{C})$ catalyst diluted with $0.05 \mathrm{~g}$ quartz chips was loaded in the reactor and reduced at $400{ }^{\circ} \mathrm{C}$ for $3 \mathrm{hrs}$. The total inlet flow rate of gases was varied from $50 \mathrm{scc} / \mathrm{min}$ to $400 \mathrm{scc} / \mathrm{min}$. The concentration of inert was $90 \%$ and the $\mathrm{O}_{2} / \mathrm{C}_{3} \mathrm{H}_{8}$ ratio was 1.78 . The same reaction conditions were used for $0.02 \mathrm{~g}$ of catalyst. The same procedure was followed for studying effect of flow for $1 \% \mathrm{Pt} / \mathrm{Al}_{2} \mathrm{O}_{3}$ catalyst.

\subsubsection{Dry reforming of propane}

Dry reforming of propane was carried out at $600{ }^{\circ} \mathrm{C}$ to check if $1 \% \mathrm{Pt} / \mathrm{CeO}_{2}(\mathrm{C})$ and $1 \% \mathrm{Pt} / \mathrm{Al}_{2} \mathrm{O}_{3}$ are active for this reaction at $600{ }^{\circ} \mathrm{C}$. The reaction was carried out at atmospheric pressure. Partial oxidation was carried out on the catalyst first to make sure that the catalyst was active and behaving as expected before the dry reforming experiment was attempted. Initially, $0.02 \mathrm{~g}$ of catalyst was loaded in the reactor and reduced at $400{ }^{\circ} \mathrm{C}$ for $3 \mathrm{hrs}$. Then, the partial oxidation reaction was carried out for the total flow rates 300 scc/min and $100 \mathrm{scc} / \mathrm{min}$. The concentration of inert was $90 \%$ and the $\mathrm{O}_{2} / \mathrm{C}_{3} \mathrm{H}_{8}$ ratio was 1.78. The catalyst activity was measured. Then the oxygen flow was turned off and $\mathrm{CO}_{2}$ was added to reaction mixture. The reaction mixture for dry reforming contained propane, nitrogen, argon and carbon dioxide. The concentration of inert was $86 \%$ and $\mathrm{CO}_{2} / \mathrm{C}_{3} \mathrm{H}_{8}$ ratio was 3 (stoichiometric ratio for dry reforming). The same flow rate of propane gas was maintained as was used for partial oxidation. The total inlet flow rate of gases was varied from $100 \mathrm{scc} / \mathrm{min}$ to $300 \mathrm{scc} / \mathrm{min}$. 


\subsubsection{Characterization}

The characterization of the $\mathrm{Pt} / \mathrm{CeO}_{2}$ and $\mathrm{Pt} / \mathrm{Al}_{2} \mathrm{O}_{3}$ catalysts is done by measuring BET surface area and Pt dispersion.

\subsubsection{BET surface area measurement}

The Brunauer-Emmett-Teller (BET) surface area measurements were performed by James Wright of the Department of Chemical Engineering, West Virginia University, Morgantown.

\subsubsection{Platinum dispersion measurement}

Platinum dispersion measurements were carried out by Dr. Tapan Das. Platinum dispersion was measured by hydrogen chemisorption technique. Temperature programmed reduction (TPR) was carried out for $1 \% \mathrm{Pt}_{\mathrm{Al}} \mathrm{O}_{3}$ catalyst from room temperature up to 400 ${ }^{\circ} \mathrm{C}$. The catalyst was held at $400{ }^{\circ} \mathrm{C}$ for $2 \mathrm{hrs}$. Then it was cooled down to $100{ }^{\circ} \mathrm{C}$. Then hydrogen flow was turned off and flow of argon gas was turned on. Temperature programmed desorption is carried out in argon flow up to $550{ }^{\circ} \mathrm{C}$. Platinum dispersion measurement of ceria catalysts was carried out in similar way. Platinum dispersion was measured by measuring the difference between chemisorbed hydrogen of ceria supports alone and $\mathrm{Pt} / \mathrm{CeO}_{2}$ catalysts. Ceria supports and catalysts were reduced at $550{ }^{\circ} \mathrm{C}$ instead of $400{ }^{\circ} \mathrm{C}$.

\subsubsection{Safety Requirements}

Safety is a concern since propane oxidation is an exothermic reaction. Major areas of concern are operation at high temperature, toxicity of chemicals, flammability of hydrogen, explosive range of operation with propane-oxygen mixtures, and mechanical and electrical connections. 
All the experiments were carried out in the chemical hood. Safety goggles, gloves and laboratory coat are necessary all the time during experiment. Attention was paid during preparation of catalyst as platinum chloride, which is used for catalyst preparation, is toxic and can cause irritation to skin and eyes. As propane and oxygen can form explosive mixtures, care was taken to ensure that operating conditions are beyond explosive limits. The explosion was avoided by keeping high concentration of inert (about $90 \%$ ) in the feed gases.

The laboratory is equipped with chemical hoods, fire extinguishers, chemical safety showers, and eye wash stations. Other available equipments include gloves, masks, laboratory coats and safety goggles. Material safety data sheets (MSDS) have been obtained for the chemicals used. A list of people to contact in case of emergency is posted at the entrance of the laboratory. 


\section{Chapter 4: Effect of Temperature}

\subsection{Preliminary Results}

Prior to catalytic testing, a blank reaction test was performed with a stainless-steel reactor, without any catalyst. Results for the blank run show that the light-off temperature (when the oxidation starts) is $600{ }^{\circ} \mathrm{C}$ and all the reacted propane is converted into $\mathrm{CO}_{2}$. The conversion of propane is $13 \%$ at $600{ }^{\circ} \mathrm{C}$. The details of the calculation procedure for the conversions and selectivities are given in Appendix $\mathrm{C}$. The results for blank reaction for stainless-steel reactor are given in Table 4.1.

Table 4.1 Effect of temperature on the activity of the stainless-steel reactor for partial oxidation of propane (total flow rate $=300 \mathrm{scc} / \mathrm{min}, \mathrm{O}_{2} / \mathrm{C}_{3} \mathrm{H}_{8}=1.78$ )

\begin{tabular}{|c|c|c|c|c|c|}
\hline $\begin{array}{c}\text { Temperature } \\
(\mathbf{0} \mathbf{C})\end{array}$ & $\mathbf{X}_{\mathbf{C 3 H 8}}, \boldsymbol{\%}$ & $\mathbf{X}_{\mathbf{O} 2}, \boldsymbol{\%}$ & $\mathbf{S}_{\mathbf{H 2}}, \boldsymbol{\%}$ & $\mathbf{S}_{\mathbf{C O}}, \boldsymbol{\%}$ & $\mathbf{S}_{\mathbf{C O 2}}, \boldsymbol{\%}$ \\
\hline 300 & 0 & 0 & 0 & 0 & 0 \\
\hline 400 & 0 & 0 & 0 & 0 & 0 \\
\hline 500 & 3.4 & 2.3 & 0 & 0 & 0 \\
\hline 600 & 12.8 & 16.8 & 0 & 0 & 29.1 \\
\hline 700 & 31.1 & 52.5 & 0.5 & 0 & 50.9 \\
\hline 800 & 63.0 & 100 & 5.7 & 6.1 & 50.1 \\
\hline
\end{tabular}

The first part of preliminary experiments was to carry out partial oxidation reaction using commercial Pt/alumina catalyst. The second part was to prepare and test the catalytic activity of $\mathrm{Pt} /$ ceria catalyst. For this, $0.5 \% \mathrm{Pt} / \mathrm{CeO}_{2}(\mathrm{~A})$ catalyst was used. The results for preliminary experiments are given in Section 4.1.1 and 4.1.2. 


\subsubsection{Commercial $\mathrm{Pt} / \mathrm{Al}_{2} \mathrm{O}_{3}$ catalyst}

The commercial $5 \% \mathrm{Pt} / \mathrm{Al}_{2} \mathrm{O}_{3}$ (wt \%) catalyst was obtained from Pressure Chemical Co. The materials are given in Section 3.2.4.1 and the methodology is given in Section 3.2.4.2.

Figure 4.1 shows the effect of temperature on partial oxidation of propane over $5 \%$ $\mathrm{Pt} / \mathrm{Al}_{2} \mathrm{O}_{3}$ catalyst. The outlet volumetric flow rates of reactants and products are plotted against temperature. Oxygen is the limiting reactant in the feed and thus is completely consumed at all the temperatures. As the temperature increases, the outlet volumetric flow rate of propane decreases which indicates that the conversion of propane increases. Below $500{ }^{\circ} \mathrm{C}$, propane is converted to $\mathrm{CO}_{2}$ and $\mathrm{H}_{2} \mathrm{O}$ exclusively. It can be seen from Figure 4.1 that the hydrogen production starts at around $400{ }^{\circ} \mathrm{C}$. Productions of hydrogen and carbon monoxide increase with temperature and reach maxima at $800{ }^{\circ} \mathrm{C}$. Propane conversion is almost constant until $500{ }^{\circ} \mathrm{C}$, but after that temperature, propane conversion increases. Propane is completely consumed at $800{ }^{\circ} \mathrm{C}$. As the temperature increases, carbon dioxide production decreases. The outlet flow rate of methane is very low and always below 1 $\mathrm{scc} / \mathrm{min}$.

From Figure 4.1 it can be concluded that the reaction shows two regimes. The regime below $500{ }^{\circ} \mathrm{C}$ is a total combustion regime and the regime above $500{ }^{\circ} \mathrm{C}$ is a reforming regime. These results are comparable to the results obtained by Maillet $e t$ al. (1996). 


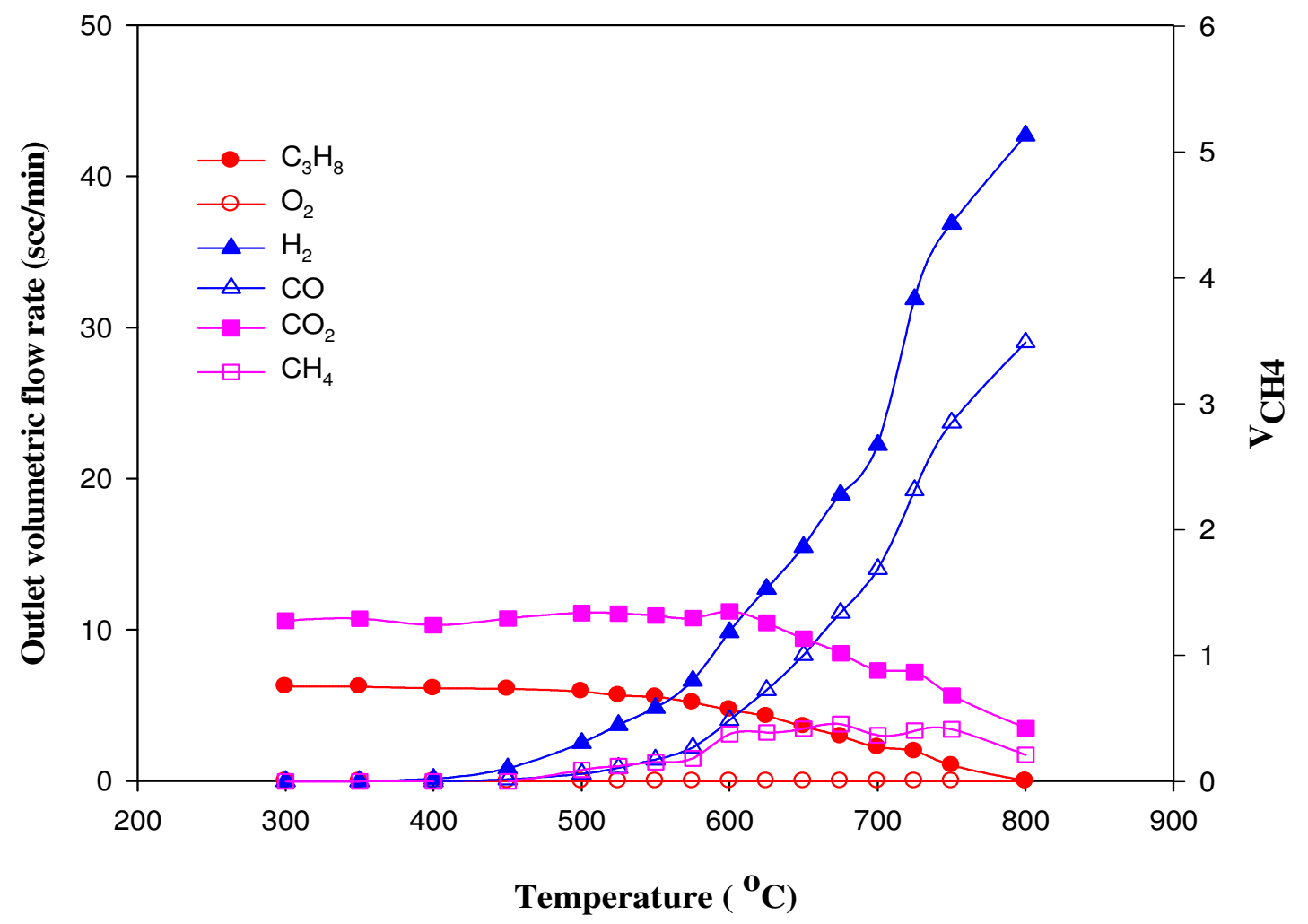

Figure 4.1 Effect of temperature on activities and product distribution over $5 \%$ $\mathrm{Pt} / \mathrm{Al}_{2} \mathrm{O}_{3}$ commercial catalyst (Feed ratio: $\mathrm{O}_{2} / \mathrm{C}_{3} \mathrm{H}_{8}=1.78$, total feed rate: $300 \mathrm{scc} / \mathrm{min}$ )

\subsubsection{Ceria supported Pt catalyst}

The $0.5 \% \mathrm{Pt} / \mathrm{CeO}_{2}$ (A) catalyst was used for this study. The Brunauer -Emmett Teller (BET) surface area of the catalyst was $16.83 \mathrm{~m}^{2} / \mathrm{g}$. The total pore volume of the sample was $0.045 \mathrm{ml} / \mathrm{g}$. The materials are given in Section 3.2.4.1 and the methodology is given in Section 3.2.4.2.

Figure 4.2 shows the effect of temperature on the partial oxidation of propane over $0.5 \% \mathrm{Pt} / \mathrm{CeO}_{2}$ (A) catalyst in the increasing-temperature mode. As expected, the volumetric flow rate of propane decreases with temperature indicating conversion of propane increases with temperature. It can be seen from Figure 4.2 that oxygen is completely consumed at all temperatures. Hydrogen and carbon monoxide production start taking place at $600^{\circ} \mathrm{C}$ and then increase with temperature. Hydrogen and carbon monoxide 
production reach maxima at $800{ }^{\circ} \mathrm{C}$. Carbon dioxide production drops as temperature increases. Production of methane is very low and always below $1 \mathrm{scc} / \mathrm{min}$.

Table 4.2 shows effect of time on stream on stability of the catalyst. The reactor temperature is brought down to $700{ }^{\circ} \mathrm{C}$ to study the deactivation, if any is taking place. After the temperature is brought back to $700{ }^{\circ} \mathrm{C}$ and is held for $3 \mathrm{hrs}$, the catalyst does not show any deactivation. It is interesting to note that the values for conversions and selectivities for these runs are greater than that of initial reading taken at $700{ }^{\circ} \mathrm{C}$, also shown in Table 4.2. This can be attributed to the stabilization of the catalyst by reaction at $800^{\circ} \mathrm{C}$.

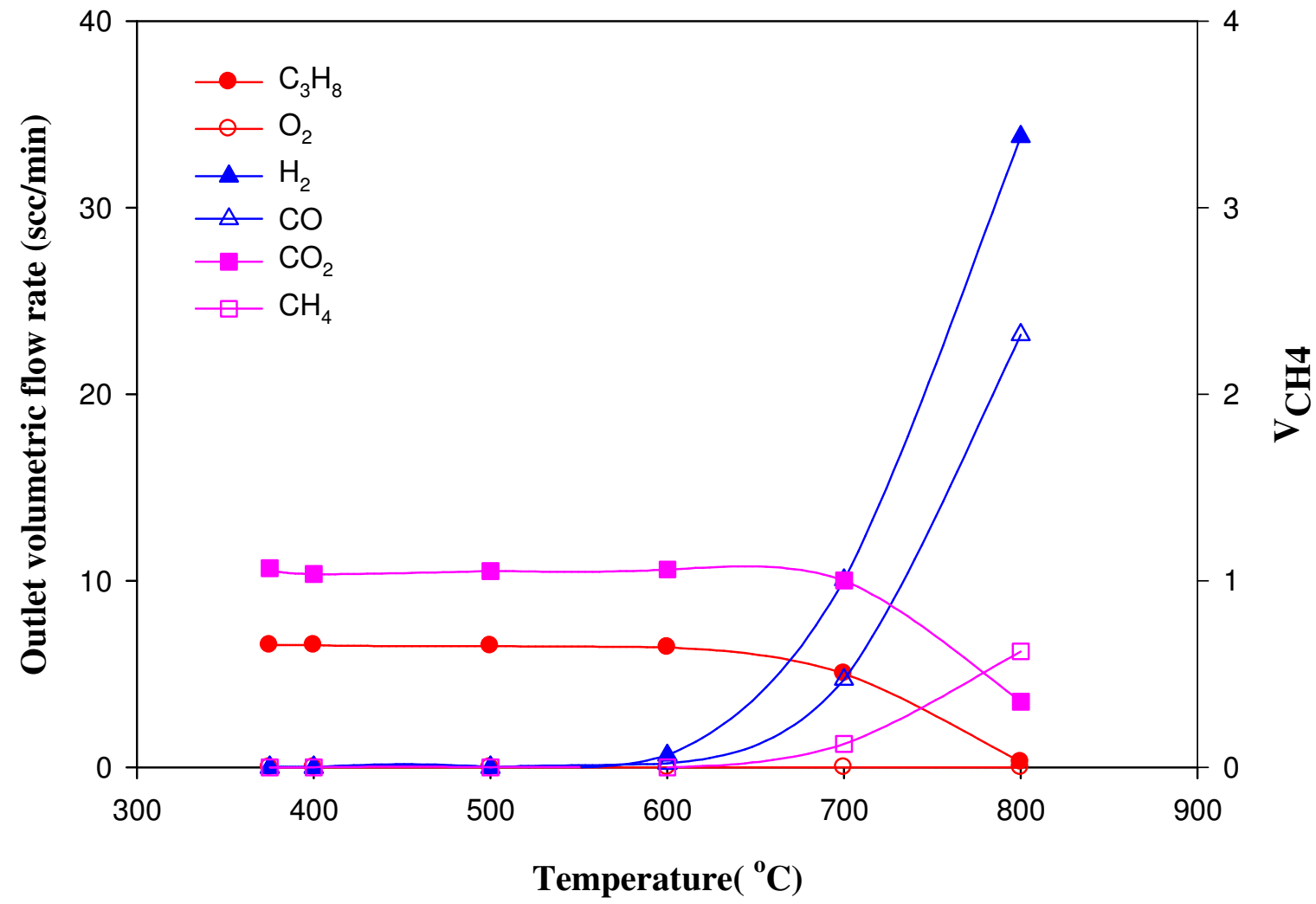

Figure 4.2 Effect of temperature on activities and product distribution over $0.5 \%$ $\mathrm{Pt} / \mathrm{CeO}_{2}$ (A) catalyst (Feed ratio: $\mathrm{O}_{2} / \mathrm{C}_{3} \mathrm{H}_{8}=1.78$, total feed rate: $300 \mathrm{scc} / \mathrm{min}$ ) 
Table 4.2 Effect of time on stream on stability of the $0.5 \% \mathrm{Pt} / \mathrm{CeO}_{2}(\mathrm{~A})$ catalyst at $700{ }^{\circ} \mathrm{C}$ (Feed ratio: $\mathrm{O}_{2} / \mathrm{C}_{3} \mathrm{H}_{8}=1.78$, total feed rate: $300 \mathrm{scc} / \mathrm{min}$ )

\begin{tabular}{|c|c|c|c|c|c|c|}
\hline $\begin{array}{c}\text { Time } \\
(\mathbf{h r s})\end{array}$ & $\mathbf{X}_{\mathbf{C 3 H 8}}$ & $\mathbf{X}_{\mathbf{O 2}}$ & $\mathbf{S}_{\mathbf{H} 2}$ & $\mathbf{S}_{\mathbf{C O}}$ & $\mathbf{S}_{\mathbf{C O 2}}$ & $\mathbf{S}_{\mathbf{C H} 4}$ \\
\hline$*$ & 54.11 & 100 & 42.40 & 26.51 & 56.36 & 0.70 \\
\hline 1 & 58.91 & 100 & 47.86 & 34.64 & 48.76 & 0.64 \\
\hline 2 & 57.05 & 100 & 48.68 & 32.46 & 51.54 & 0.67 \\
\hline 3 & 57.50 & 100 & 45.09 & 30.40 & 56.85 & 0.66 \\
\hline
\end{tabular}

* Increasing temperature mode

\subsubsection{Summary}

The activities of the commercial $5 \% \mathrm{Pt} / \mathrm{Al}_{2} \mathrm{O}_{3}$ catalyst and of $0.5 \% \mathrm{Pt} / \mathrm{CeO}_{2}(\mathrm{~A})$ were studied for partial oxidation of propane with $\mathrm{O}_{2} / \mathrm{C}_{3} \mathrm{H}_{8}=1.78$. The preliminary studies show that both catalysts are active for this reaction. Hydrogen production starts taking place above $500{ }^{\circ} \mathrm{C}$.

The reaction follows two regimes. Below $500{ }^{\circ} \mathrm{C}$, it is a total combustion regime, where propane is converted exclusively to carbon dioxide and water. Above $500{ }^{\circ} \mathrm{C}$, is it a reforming regime, where propane is converted into carbon monoxide and hydrogen. For 0.5 $\% \mathrm{Pt} / \mathrm{CeO}_{2}$ (A) catalyst, after bringing down the temperature back to $700{ }^{\circ} \mathrm{C}$ and holding it for $3 \mathrm{hrs}$, catalyst does not show any deactivation. The values for conversions and selectivities for these runs are greater than that of initial reading taken at $700{ }^{\circ} \mathrm{C}$. This can be attributed to the stabilization of the catalyst by reaction at $800^{\circ} \mathrm{C}$. 


\subsection{Effect of support on partial oxidation of propane}

Partial oxidation of propane has been studied mainly for irreducible oxides such as $\mathrm{Al}_{2} \mathrm{O}_{3}, \mathrm{SiO}_{2}, \mathrm{MgO}$ etc. The reducible oxides like $\mathrm{CeO}_{2}$ can offer additional benefits for the reaction due to their oxygen storage capacity. There have been reports on the reaction regimes, total combustion being the first regime and reforming being the second regime (Pantu and Gavalas, 2002).

In this section, the effect of temperature is studied for the partial oxidation of propane using $\mathrm{Pt} / \mathrm{CeO}_{2}$ (B) and $\mathrm{Pt} / \mathrm{CeO}_{2}(\mathrm{C}$ ). Both the catalysts contain $1 \%$ (wt \%) $\mathrm{Pt}$ metal. The results are also compared with the $1 \% \mathrm{Pt} / \mathrm{Al}_{2} \mathrm{O}_{3}$ catalyst. The effect of temperature on $0.5 \% \mathrm{Pt} / \mathrm{CeO}_{2}$ (A) was discussed in Section 4.1.2. The similar behavior is observed for $1 \% \mathrm{Pt} / \mathrm{CeO}_{2}$ (A) catalyst and hence it is not discussed in this chapter but the quantitative comparison is made between $1 \% \mathrm{Pt} / \mathrm{CeO}_{2}(\mathrm{~A}), 1 \% \mathrm{Pt} / \mathrm{CeO}_{2}(\mathrm{~B}), 1 \% \mathrm{Pt} / \mathrm{CeO}_{2}$ (C) and $1 \% \mathrm{Pt}_{2} \mathrm{Al}_{2} \mathrm{O}_{3}$ catalysts later in this chapter.

\subsubsection{Pt/CeO $(\mathrm{B})$ catalyst}

The $1 \% \mathrm{Pt} / \mathrm{CeO}_{2}$ (B) catalyst is tested for effect of temperature in increasing temperature mode. The materials are given in Section 3.2.4.1 and the methodology is given in Section 3.2.4.2.

Figure 4.3 shows the effect of temperature on partial oxidation of propane over $1 \%$ $\mathrm{Pt} / \mathrm{CeO}_{2}$ (B) catalyst. The outlet flow rate of propane decreases with increase in temperature. This indicates that conversion of propane increases with temperature. Oxygen is completely consumed above $500{ }^{\circ} \mathrm{C}$. Productions of hydrogen and carbon monoxide are measurable above $500{ }^{\circ} \mathrm{C}$. The products increase with increase in temperature. Carbon dioxide production initially increases with temperature, but above $400^{\circ} \mathrm{C}$, reforming reactions become important and production of carbon dioxide levels off. Carbon dioxide production starts decreasing around $650{ }^{\circ} \mathrm{C}$. Methane formation is low and always below $1.2 \mathrm{scc} / \mathrm{min}$. 


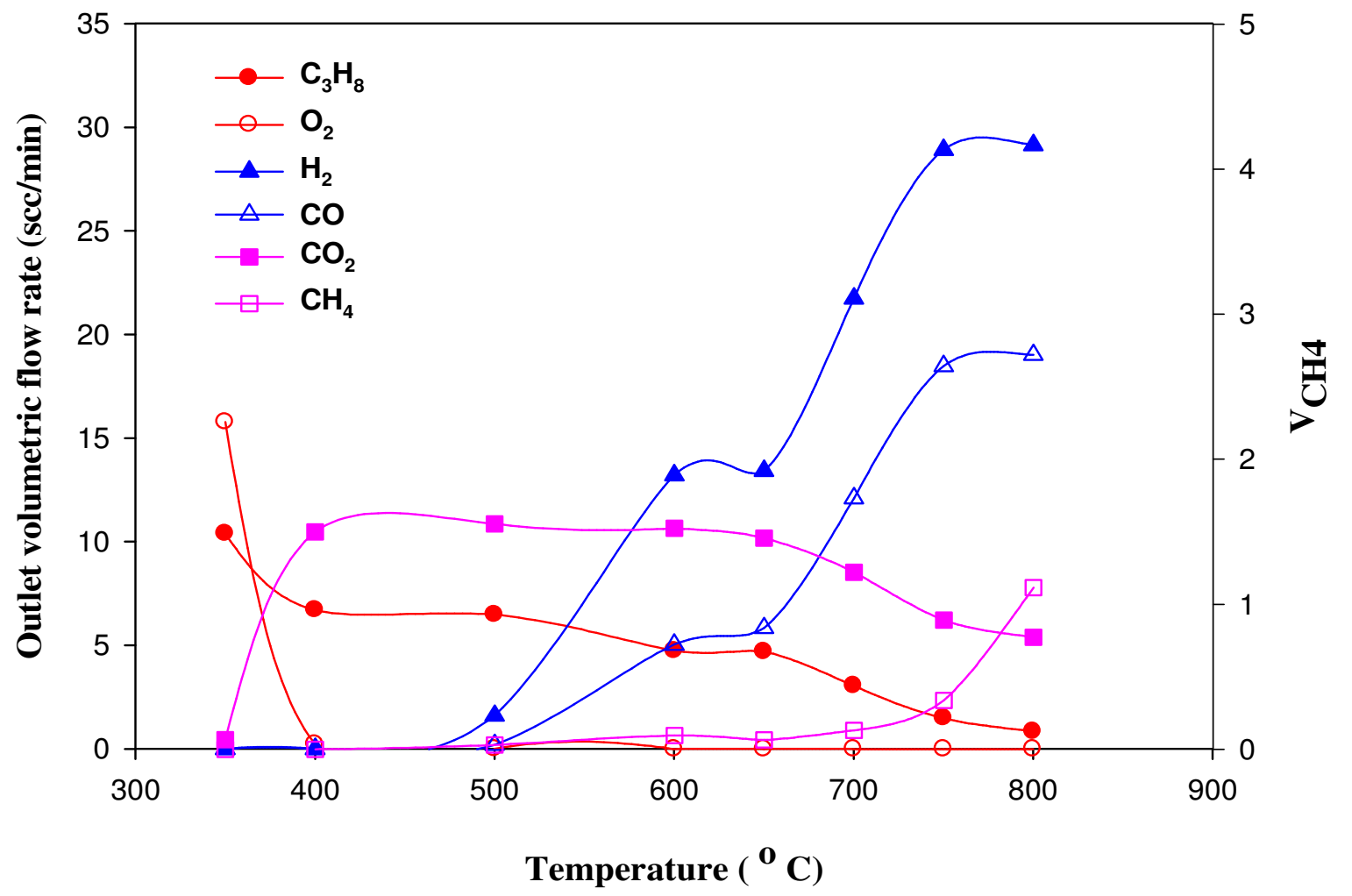

Figure 4.3 Effect of temperature on activities and product distribution over $1 \%$ $\mathrm{Pt} / \mathrm{CeO}_{2}$ (B) catalyst (Feed ratio: $\mathrm{O}_{2} / \mathrm{C}_{3} \mathrm{H}_{8}=1.78$, total feed rate: $300 \mathrm{scc} / \mathrm{min}$ )

\subsubsection{Pt/CeO $(\mathrm{C})$ Catalyst}

The $1 \% \mathrm{Pt} / \mathrm{CeO}_{2}$ (C) catalyst is tested for effect of temperature in increasing temperature mode. The materials are given in Section 3.2.4.1 and the methodology is given in Section 3.2.4.2.

Figure 4.4 shows the effect of temperature on partial oxidation over $1 \% \mathrm{Pt} / \mathrm{CeO}_{2}$ (C) catalyst. The volumetric flow rate of propane decreases with increase in temperature indicating an increase in conversion with temperature. Oxygen is not completely consumed at all temperatures. Below $500{ }^{\circ} \mathrm{C}$, some oxygen is observed and it is completely consumed above $500{ }^{\circ} \mathrm{C}$. More oxygen and propane is observed below $500{ }^{\circ} \mathrm{C}$ as compared to $1 \%$ $\mathrm{Pt} / \mathrm{CeO}_{2}$ (B) which indicate that conversion of propane and oxygen is higher for $1 \%$ 
$\mathrm{Pt} / \mathrm{CeO}_{2}(\mathrm{~B})$ than $1 \% \mathrm{Pt} / \mathrm{CeO}_{2}(\mathrm{C})$ below $500^{\circ} \mathrm{C}$. Production of hydrogen starts at $450{ }^{\circ} \mathrm{C}$. Productions of hydrogen and carbon monoxide increase with increase in temperature and reaches maxima at $750^{\circ} \mathrm{C}$. Carbon dioxide production levels off at $550^{\circ} \mathrm{C}$ and then decreases with temperature.

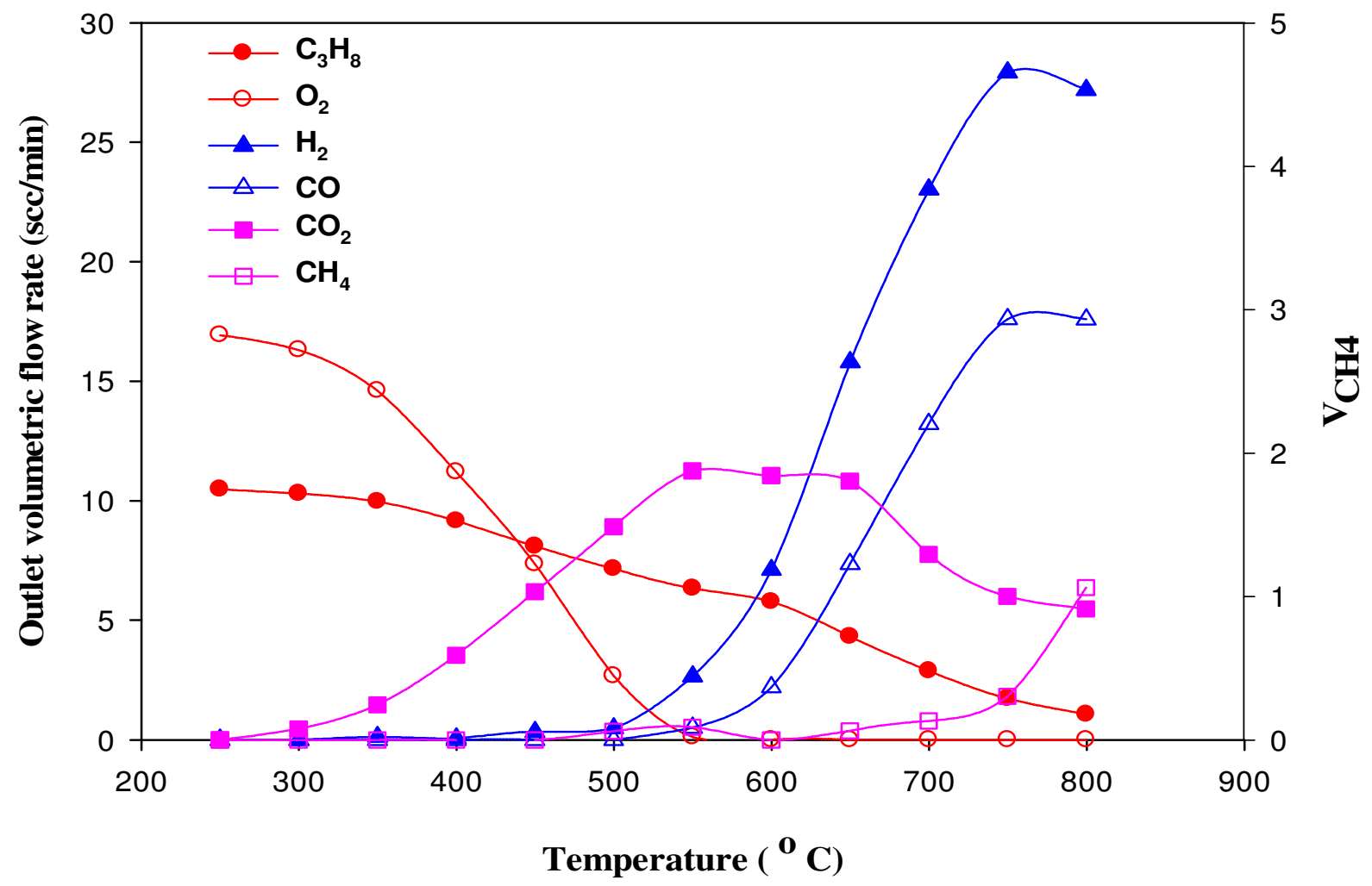

Figure 4.4 Effect of temperature on activities and product distribution over $1 \%$ $\mathrm{Pt} / \mathrm{CeO}_{2}(\mathrm{C})$ catalyst (Feed ratio: $\mathrm{O}_{2} / \mathrm{C}_{3} \mathrm{H}_{8}=1.78$, total feed rate: $300 \mathrm{scc} / \mathrm{min}$ ) 


\subsubsection{Pt/ $/ \mathrm{Al}_{2} \mathrm{O}_{3}$ Catalyst}

The $1 \% \mathrm{Pt} / \mathrm{Al}_{2} \mathrm{O}_{3}$ catalyst is used for comparison with results obtained for $\mathrm{Pt} / \mathrm{CeO}_{2}$ catalysts. The materials are given in Section 3.2.4.1 and the methodology is given in Section 3.2.4.2.

Figure 4.5 shows the effect of temperature on partial oxidation of propane over $1 \%$ $\mathrm{Pt} / \mathrm{Al}_{2} \mathrm{O}_{3}$ catalyst. The outlet flow rate of propane decreases with increasing temperature indicating the conversion is increasing. Oxygen is consumed completely at all temperatures. Productions of hydrogen and carbon monoxide start taking place at $500{ }^{\circ} \mathrm{C}$ and increase with increasing temperature. The outlet flow rate of carbon dioxide is almost constant up to $600{ }^{\circ} \mathrm{C}$ and then decreases with temperature. The trends observed for all the products are same as observed with $\mathrm{Pt} / \mathrm{CeO}_{2}$ catalysts. The conversions and selectivities over different catalysts are quantitatively analyzed in Section 4.2.6.

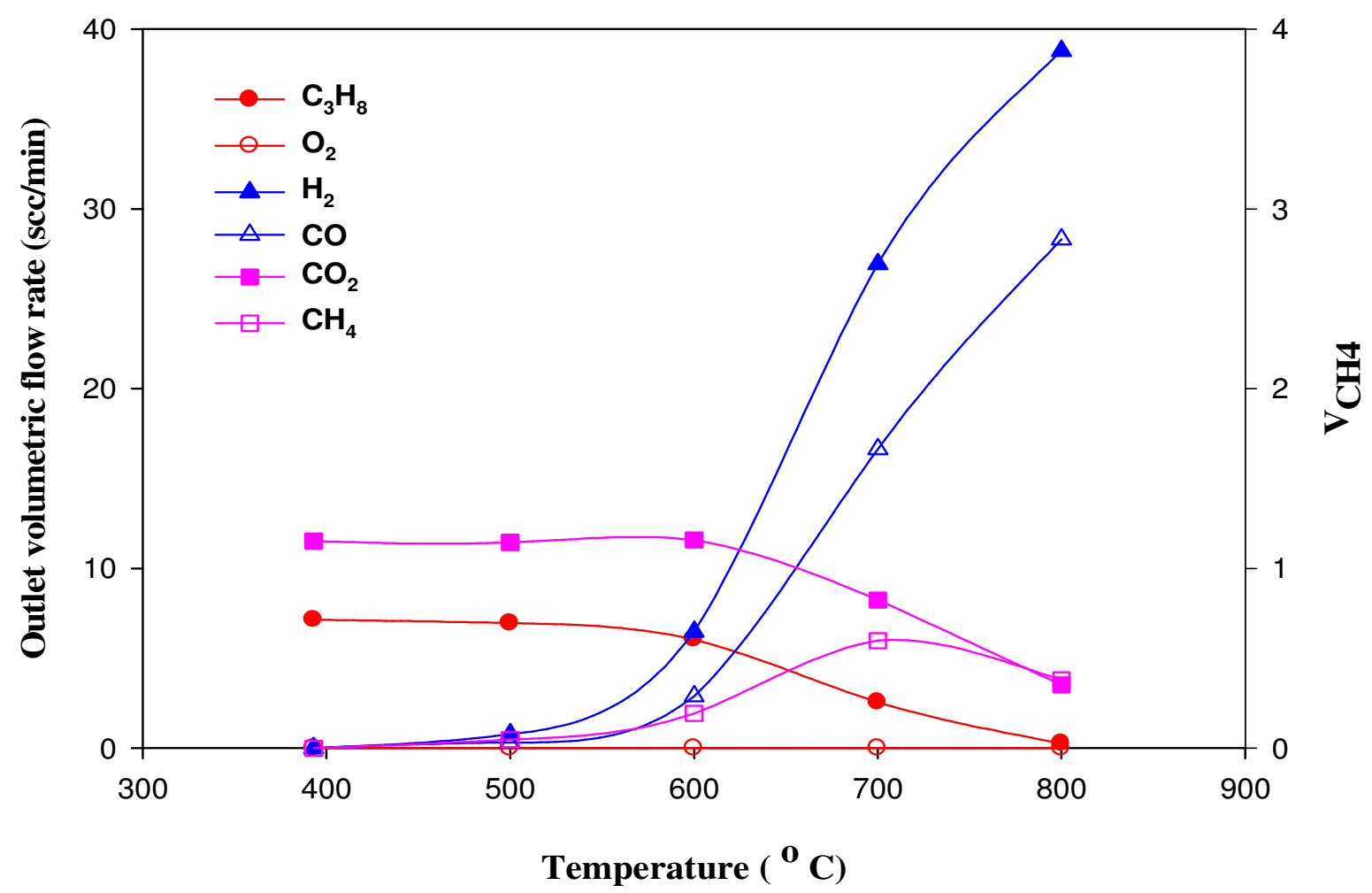

Figure 4.5 Effect of temperature on activities and product distribution over $1 \% \mathrm{Pt}_{\mathbf{A}} \mathrm{Al}_{2} \mathrm{O}_{3}$ catalyst (Feed ratio: $\mathrm{O}_{2} / \mathrm{C}_{3} \mathrm{H}_{8}=1.78$, total feed rate: $300 \mathrm{scc} / \mathrm{min}$ ) 


\subsubsection{Study of Thermal Stability}

The thermal stability of ceria supports and catalysts were studied under $\mathrm{N}_{2}$ atmosphere. The materials and methodology for this experiment are given in Section 3.2.4.3.

Table 4.3 shows the thermal stability of ceria supports and catalysts. The BET surface area of fresh samples of $\mathrm{CeO}_{2}(\mathrm{~B})$ and $\mathrm{CeO}_{2}(\mathrm{C})$ are 4-5 times larger than that of $\mathrm{CeO}_{2}(\mathrm{~A})$. After thermal treatment, surface areas of $\mathrm{CeO}_{2}(\mathrm{~B})$ and $\mathrm{CeO}_{2}(\mathrm{C})$ supports and 1 $\% \mathrm{Pt} / \mathrm{CeO}_{2}(\mathrm{~B})$ and $1 \% \mathrm{Pt} / \mathrm{CeO}_{2}(\mathrm{C})$ drop drastically. It is interesting to note that, though BET surface area of fresh $\mathrm{CeO}_{2}(\mathrm{C})$ is larger than $\mathrm{CeO}_{2}(\mathrm{~B}), \mathrm{CeO}_{2}(\mathrm{~B})$ has a larger BET surface area than $\mathrm{CeO}_{2}(\mathrm{C})$ after heat treatment and so does the catalyst. The loss of BET surface areas can be attributed to loss of microporous surface followed by sintering of particles (Perrichon et al., 1995).

Table 4.3 Thermal stability analysis of different ceria supports and catalysts

\begin{tabular}{|c|c|c|}
\hline Support/Catalyst & $\begin{array}{c}\text { BET surface area } \\
\text { (Fresh sample), }\left(\mathbf{m}^{2} / \mathbf{g}\right)\end{array}$ & $\begin{array}{c}\text { BET surface area after heating at } \\
\mathbf{9 0 0}^{\mathbf{0}} \mathbf{C} \text { in } \mathbf{~}_{\mathbf{2}} \text { flow for } \mathbf{2 4} \mathbf{~ h r s ~}\left(\mathbf{m}^{2} / \mathbf{g}\right)\end{array}$ \\
\hline $\mathrm{CeO}_{2}(\mathrm{~A})$ & 17.3 & 5.1 \\
\hline $\mathrm{CeO}_{2}(\mathrm{~B})$ & 69.6 & 17.1 \\
\hline $\mathrm{CeO}_{2}(\mathrm{C})$ & 84.7 & 6.1 \\
\hline $1 \% \mathrm{Pt} / \mathrm{CeO}_{2}(\mathrm{~A})$ & 9.9 & 6.7 \\
\hline $1 \% \mathrm{Pt} / \mathrm{CeO}_{2}(\mathrm{~B})$ & 65.8 & 15.5 \\
\hline $1 \% \mathrm{Pt} / \mathrm{CeO}_{2}(\mathrm{C})$ & 80.4 & 5.5 \\
\hline
\end{tabular}

A-Commercial ceria, B- Precipitation method, C- Decomposition method

\subsubsection{Platinum dispersion studies}

Platinum dispersion was measured for $1 \% \mathrm{Pt} / \mathrm{CeO}_{2}(\mathrm{~A}), 1 \% \mathrm{Pt} / \mathrm{CeO}_{2}(\mathrm{~B}), 1 \%$ $\mathrm{Pt} / \mathrm{CeO}_{2}(\mathrm{C})$ and $1 \% \mathrm{Pt} / \mathrm{Al}_{2} \mathrm{O}_{3}$ catalysts. The materials and methodology are given in Section 3.2.5.2. 
Table 4.4 gives platinum dispersion values for ceria and alumina supported platinum catalysts. The $1 \% \mathrm{Pt} / \mathrm{CeO}_{2}$ (A) catalyst has very poor platinum dispersion. Platinum dispersion of $1 \% \mathrm{Pt} / \mathrm{CeO}_{2}(\mathrm{C})$ is slightly higher than $1 \% \mathrm{Pt} / \mathrm{CeO}_{2}(\mathrm{~B})$. The $1 \%$ $\mathrm{Pt} / \mathrm{Al}_{2} \mathrm{O}_{3}$ has the maximum platinum dispersion which is $46 \%$.

Table 4.4 Platinum dispersion of ceria and alumina supported Pt catalysts

\begin{tabular}{|c|c|}
\hline Catalysts & Platinum dispersion (\%) \\
\hline $1 \% \mathrm{Pt} / \mathrm{CeO}_{2}(\mathrm{~A})$ & 8.4 \\
\hline $1 \% \mathrm{Pt} / \mathrm{CeO}_{2}(\mathrm{~B})$ & 34 \\
\hline $1 \% \mathrm{Pt} / \mathrm{CeO}_{2}(\mathrm{C})$ & 35 \\
\hline $1 \% \mathrm{Pt} / \mathrm{Al}_{2} \mathrm{O}_{3}$ & 46 \\
\hline
\end{tabular}

\subsubsection{Comparison of the catalysts}

Figure 4.6 compares $1 \% \mathrm{Pt} / \mathrm{CeO}_{2}(\mathrm{~A}), 1 \% \mathrm{Pt} / \mathrm{CeO}_{2}(\mathrm{~B}), 1 \% \mathrm{Pt} / \mathrm{CeO}_{2}(\mathrm{C})$ and $1 \%$ $\mathrm{Pt} / \mathrm{Al}_{2} \mathrm{O}_{3}$. The figure compares the activity and product selectivities for partial oxidation of propane at $650{ }^{\circ} \mathrm{C}$ and $700{ }^{\circ} \mathrm{C}$. The total flow rate is $300 \mathrm{scc} / \mathrm{min}$ and $\mathrm{O}_{2} / \mathrm{C}_{3} \mathrm{H}_{8}$ ratio is 1.78 .

Conversion of oxygen is always $100 \%$ for all the catalysts. The $1 \% \mathrm{Pt} / \mathrm{CeO}_{2}(\mathrm{C})$, which has the largest BET surface area and platinum dispersion among all ceria-supported catalysts, shows the highest propane conversion $\left(\mathrm{X}_{\mathrm{C} 3 \mathrm{H} 8}\right)$, the highest hydrogen selectivity $\left(\mathrm{S}_{\mathrm{H} 2}\right)$ and carbon monoxide selectivity $\left(\mathrm{S}_{\mathrm{CO}}\right)$ and the lowest carbon dioxide selectivity $\left(\mathrm{S}_{\mathrm{CO} 2}\right)$ among all ceria-supported catalysts. $1 \% \mathrm{Pt} / \mathrm{Al}_{2} \mathrm{O}_{3}$ gives the highest propane conversion, the highest hydrogen and carbon monoxide selectivities and the lowest carbon dioxide selectivity among all the catalysts. This can be explained by noting that BET surface area of $1 \% \mathrm{Pt} / \mathrm{Al}_{2} \mathrm{O}_{3}\left(153 \mathrm{~m}^{2} / \mathrm{g}\right)$ is twice that of $1 \% \mathrm{Pt} / \mathrm{CeO}_{2}$ (C) $\left(80.4 \mathrm{~m}^{2} / \mathrm{g}\right)$ and also it has higher platinum dispersion than $1 \% \mathrm{Pt} / \mathrm{CeO}_{2}(\mathrm{C})$. Also, the BET surface areas of the ceria catalysts are not stable, and the catalysts lose surface area with heat treatment. 
Ruckenstien and Wang (1999) reported that Rh supported on irreducible oxides like $\mathrm{Al}_{2} \mathrm{O}_{3}$ was more active for partial oxidation of methane than $\mathrm{Rh}$ supported on reducible oxides like $\mathrm{CeO}_{2}$. The authors suggest that the lower activity of reducible oxides is due to coverage of Rh sites by partially reduced oxide and thus, in turn, loss in active sites during reaction. Pantu and Gavalas (2002) also studied methane partial oxidation over Pt supported on $\mathrm{CeO}_{2}$ and $\mathrm{Al}_{2} \mathrm{O}_{3}$. At lower temperatures, $\mathrm{Pt} / \mathrm{CeO}_{2}$ gave higher conversion than $\mathrm{Pt} / \mathrm{Al}_{2} \mathrm{O}_{3}$ due to redox reactions. But at higher temperatures like $650^{\circ} \mathrm{C}$ and $700^{\circ} \mathrm{C}$, conversions obtained for both catalysts are very close. This is due to reduction in the promotion effect of $\mathrm{CeO}_{2}$ support.

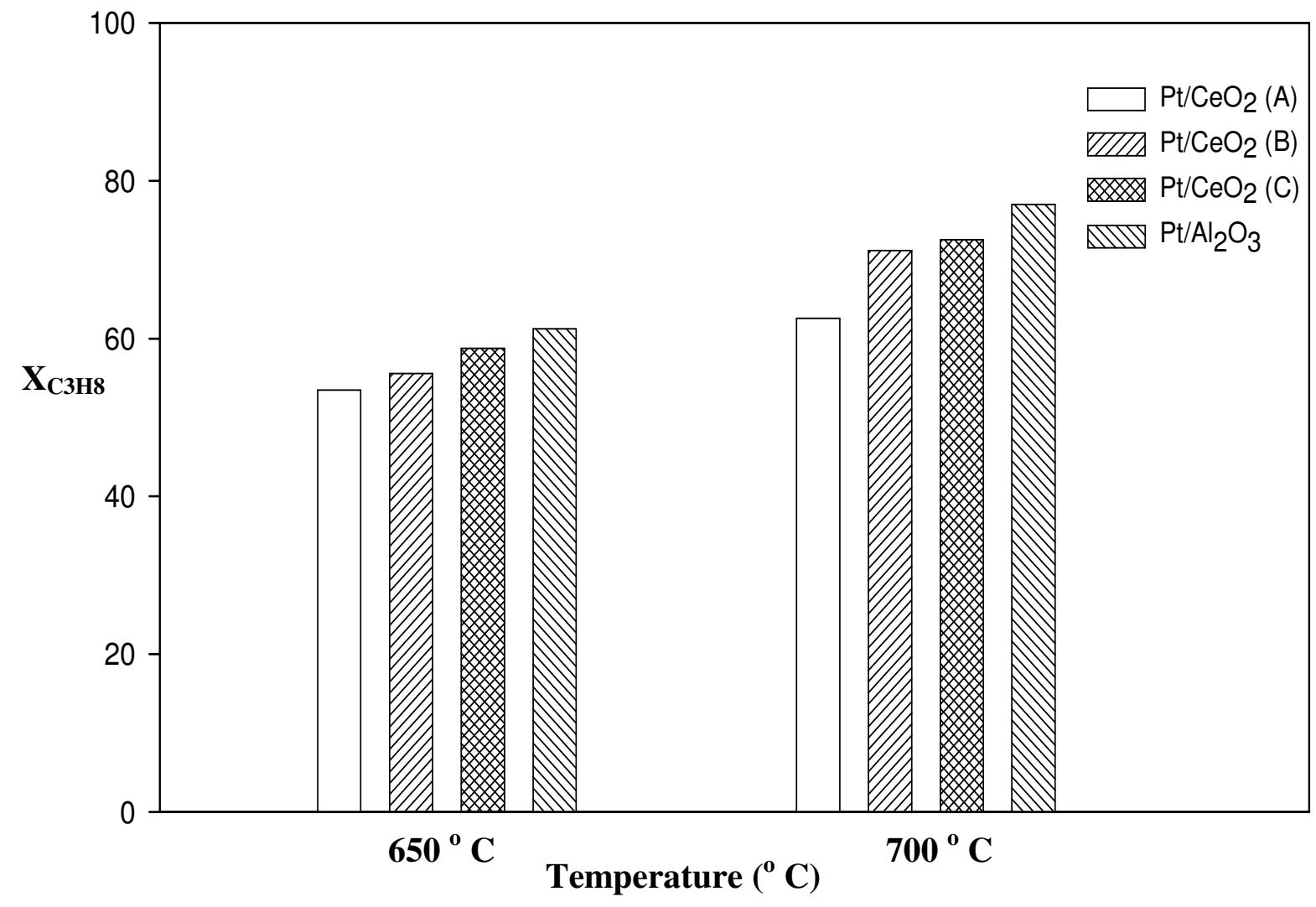

Figure 4.6 a Comparison of activities of $1 \% \mathrm{Pt} / \mathrm{CeO}_{2}$ and $1 \% \mathrm{Pt} / \mathrm{Al}_{2} \mathrm{O}_{3}$ catalysts (Total flow rate $=300 \mathrm{scc} / \mathrm{min}, \mathrm{O}_{2} / \mathrm{C}_{3} \mathrm{H}_{8}=1.78$, amount of catalyst $=0.1 \mathrm{~g}$ ) 


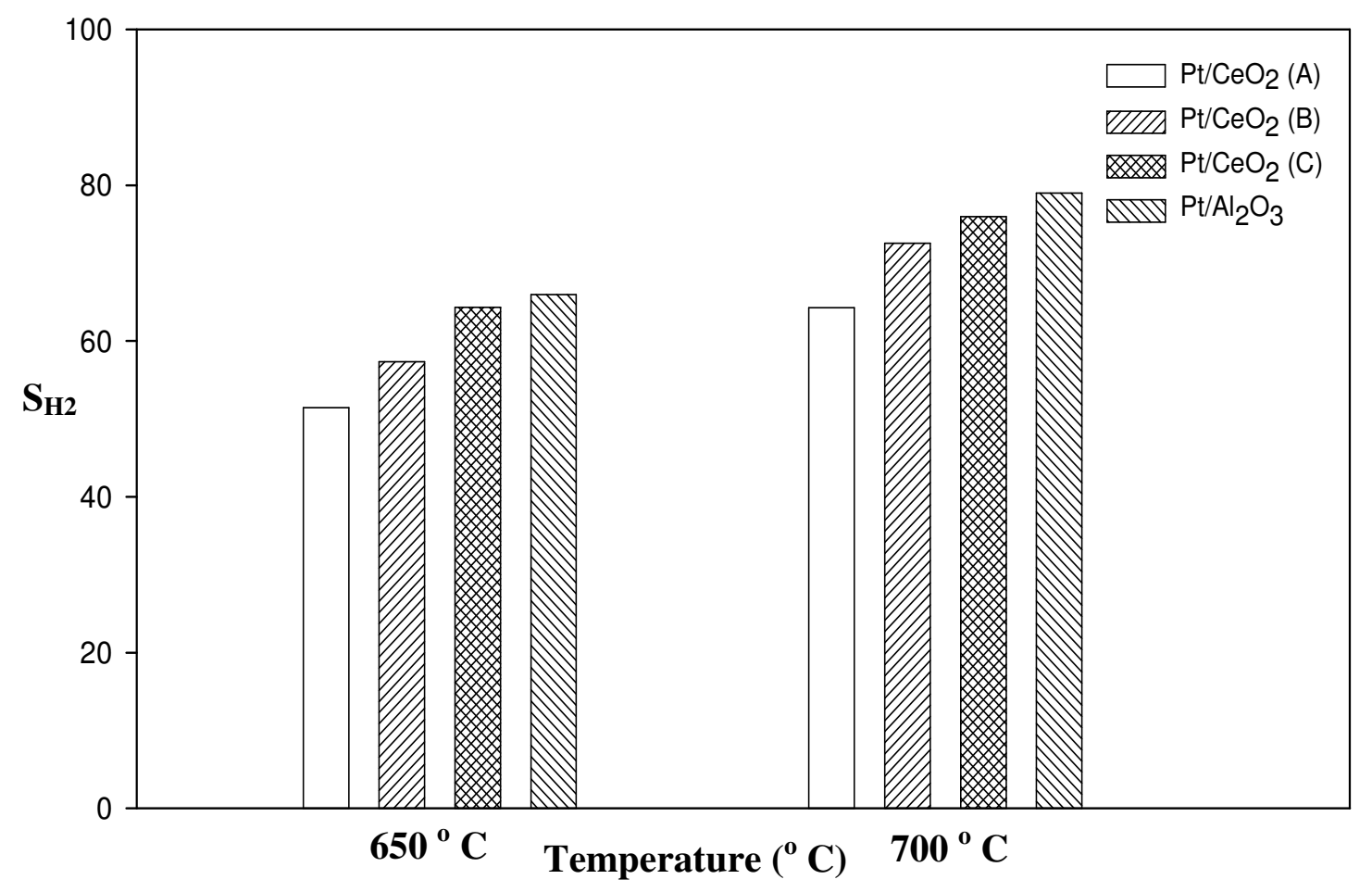

Figure 4.6 b Comparison of $\mathrm{H}_{2}$ selectivities of $1 \% \mathrm{Pt} / \mathrm{CeO}_{2}$ and $1 \% \mathrm{Pt} / \mathrm{Al}_{2} \mathrm{O}_{3}$ catalysts $\left(\right.$ Total flow rate $=300 \mathrm{scc} / \mathrm{min}, \mathrm{O}_{2} / \mathrm{C}_{3} \mathrm{H}_{8}=1.78$, amount of catalyst $=0.1 \mathrm{~g}$ )

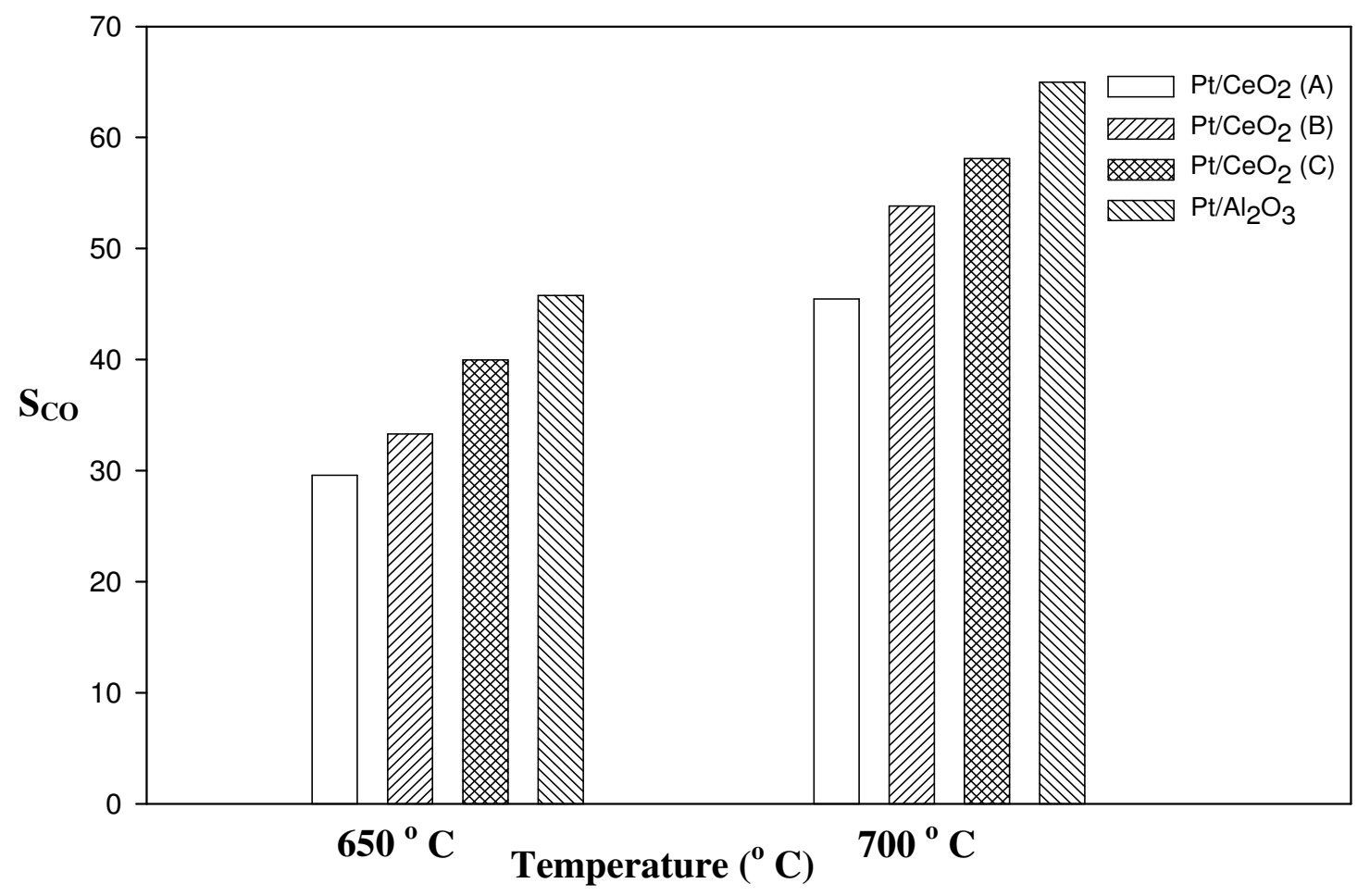

Figure 4.6 c Comparison of $\mathrm{CO}$ selectivities of $1 \% \mathrm{Pt} / \mathrm{CeO}_{2}$ and $1 \% \mathrm{Pt} / \mathrm{Al}_{2} \mathrm{O}_{3}$ catalysts $\left(\right.$ Total flow rate $=300 \mathrm{scc} / \mathrm{min}, \mathrm{O}_{2} / \mathrm{C}_{3} \mathrm{H}_{8}=1.78$, amount of catalyst $=0.1 \mathrm{~g}$ ) 


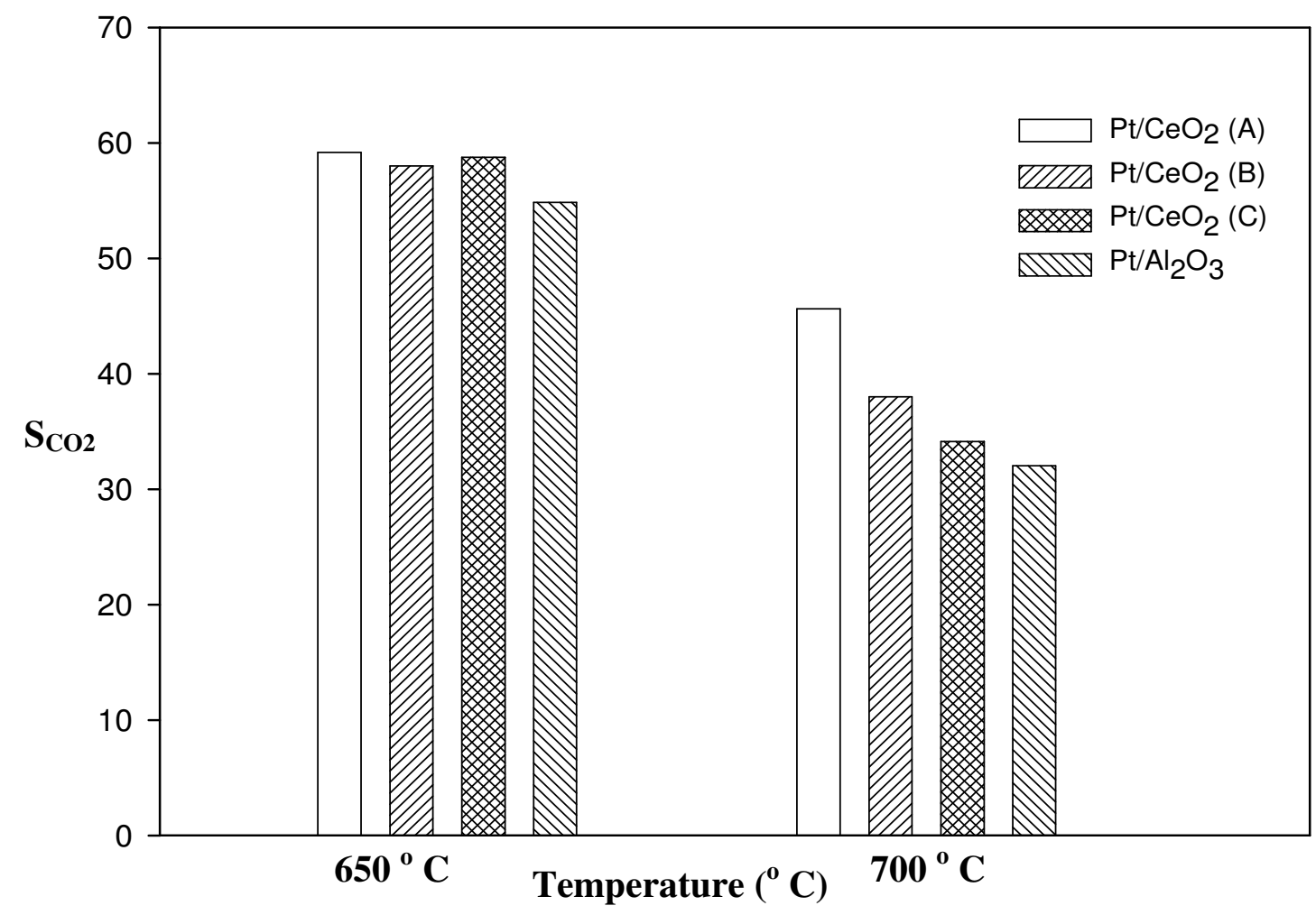

Figure 4.6 d Comparison of $\mathrm{CO}_{2}$ selectivities of $1 \% \mathrm{Pt} / \mathrm{CeO}_{2}$ and $1 \% \mathrm{Pt} / \mathrm{Al}_{2} \mathrm{O}_{3}$ catalysts $\left(\right.$ Total flow rate $=300 \mathrm{scc} / \mathrm{min}, \mathrm{O}_{2} / \mathrm{C}_{3} \mathrm{H}_{8}=1.78$, amount of catalyst $=0.1 \mathrm{~g}$ )

\subsection{Summary}

Studies of the effect of temperature for $1 \% \mathrm{Pt} / \mathrm{CeO}_{2}(\mathrm{~A}), 1 \% \mathrm{Pt} / \mathrm{CeO}_{2}(\mathrm{~B}), 1 \%$ $\mathrm{Pt} / \mathrm{CeO}_{2}(\mathrm{C})$ and $1 \% \mathrm{Pt} / \mathrm{Al}_{2} \mathrm{O}_{3}$ show that there are two domains for partial oxidation reaction. Below $500{ }^{\circ} \mathrm{C}$, complete oxidation of propane takes place to produce carbon dioxide and water. Above $500^{\circ} \mathrm{C}$, propane undergoes reforming reactions, producing hydrogen and carbon monoxide.

Ceria supports and the ceria-supported catalysts lose surface area upon heat treatment. The $1 \% \mathrm{Pt} / \mathrm{CeO}_{2}(\mathrm{C})$ catalyst, which has the largest initial BET surface area and platinum dispersion among ceria catalysts, gives the best activity and product selectivities for partial oxidation of propane among all ceria-supported catalysts. The $1 \% \mathrm{Pt} / \mathrm{Al}_{2} \mathrm{O}_{3}$ catalyst, which has BET surface area twice that of $1 \% \mathrm{Pt} / \mathrm{CeO}_{2}(\mathrm{C})$ and higher platinum dispersion, gives higher propane conversion and hydrogen selectivity than $1 \% \mathrm{Pt} / \mathrm{CeO}_{2}$ (C). 


\section{Chapter 5: Effect of Time on Stream and Feed Ratio for $1 \%$ $\mathrm{Pt} / \mathrm{CeO}_{2}(\mathrm{C})$ and $1 \% \mathrm{Pt}_{\mathrm{Al}} \mathrm{O}_{3}$}

\subsection{Introduction}

This chapter deals with the effect of $\mathrm{O}_{2} / \mathrm{C}_{3} \mathrm{H}_{8}$ ratio on the performance of $1 \%$ $\mathrm{Pt} / \mathrm{CeO}_{2}$ (C) and $1 \% \mathrm{Pt} / \mathrm{Al}_{2} \mathrm{O}_{3}$ catalysts for partial oxidation of propane. As noted in Chapter $4,1 \% \mathrm{Pt} / \mathrm{CeO}_{2}$ (C) catalyst gives the highest activity at $650{ }^{\circ} \mathrm{C}$ and $700{ }^{\circ} \mathrm{C}$ for partial oxidation of propane among all ceria-supported catalysts used here. Also, this catalyst has the largest BET surface area and Pt dispersion among all ceria-supported catalysts used here. Hence the studies are carried out using the $1 \% \mathrm{Pt} / \mathrm{CeO}_{2}$ (C) catalyst. The effect of time on stream is also studied. The stable performance of the catalyst is very important for any reaction. Hence, the stability of the catalysts is studied to check if catalysts are stable and not deactivating with time on stream.

\subsection{Effect of time on stream}

\subsection{1 $1 \% \mathrm{Pt} / \mathrm{CeO}_{2}(\mathrm{C})$ catalyst}

For the reasons mentioned above, the effect of time on stream on the performance of $1 \% \mathrm{Pt} / \mathrm{CeO}_{2}$ (C) catalyst was studied at $800{ }^{\circ} \mathrm{C}$ for 15 hours on stream. The materials are given in Section 3.2.4.1 and methodology is given in Section 3.2.4.4.

Figure 5.1 shows the time-on-stream behavior of $1 \% \mathrm{Pt} / \mathrm{CeO}_{2}(\mathrm{C})$ catalyst for the partial oxidation of propane. The initial propane conversion is $91 \%$ and hydrogen selectivity is $78 \%$. Oxygen conversion is always $100 \%$. At $\mathrm{t}=15 \mathrm{hr}$, propane conversion is $88 \%$ and hydrogen selectivity $71 \%$. The conversion of propane and selectivities of hydrogen, carbon monoxide and carbon dioxide do not change much over the time period. The rate of deactivation was calculated by linear regression of propane conversion to be 
$0.28 \%$ propane conversion/hr. This indicates that the $1 \% \mathrm{Pt} / \mathrm{CeO}_{2}(\mathrm{C})$ catalyst is stable for partial oxidation of propane and not deactivating during the course of reaction.

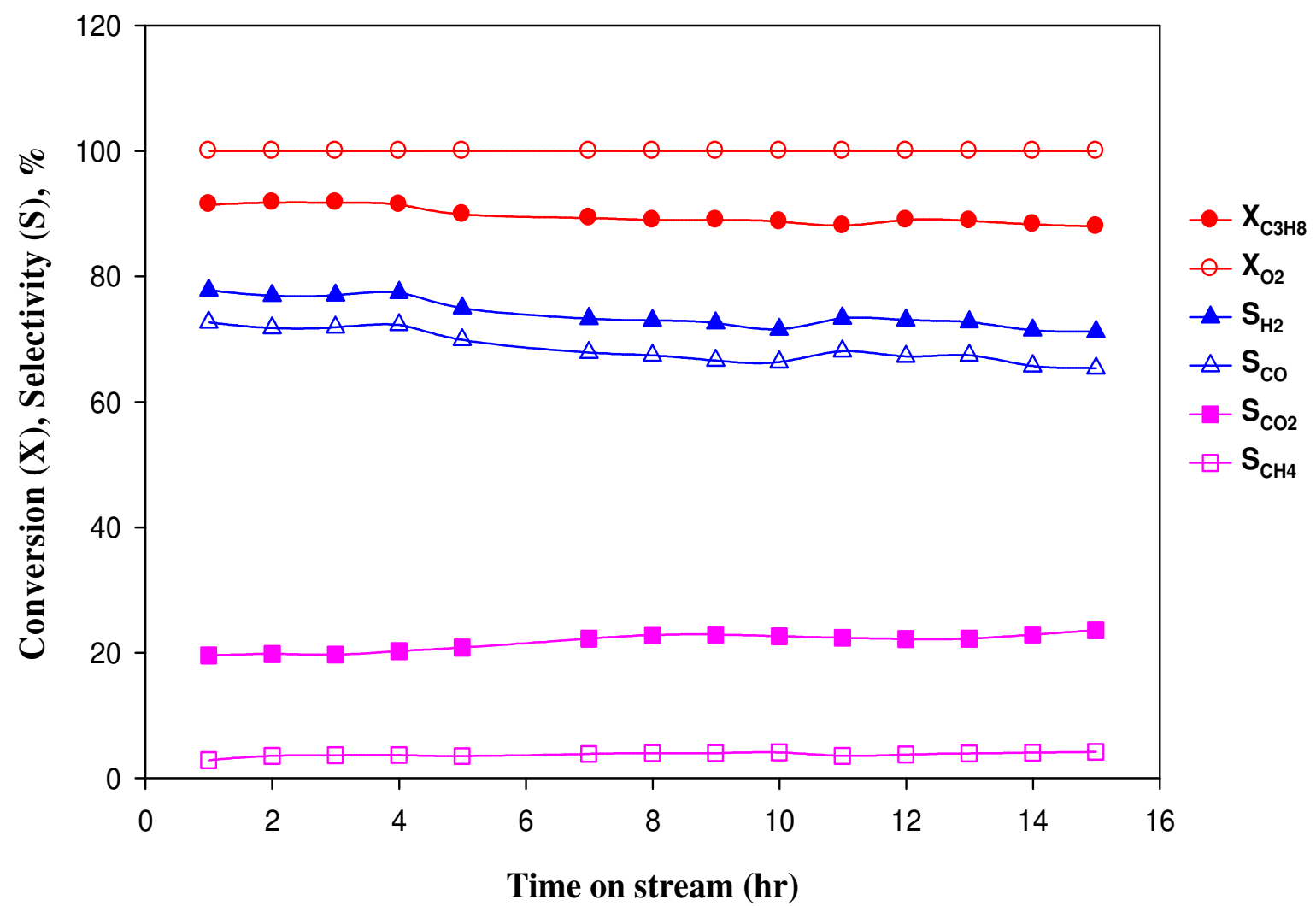

Figure 5.1 Stability of $1 \% \mathrm{Pt} \mathrm{CeO}_{2}(\mathrm{C})$ for propane activity and product selectivities against time on stream $\left(\mathrm{T}=800{ }^{\circ} \mathrm{C}\right.$, total flow rate $=300 \mathrm{scc} / \mathrm{min}$ with $90 \%$ inert $)$

\subsection{2 $1 \% \mathrm{Pt} / \mathrm{Al}_{2} \mathrm{O}_{3}$ catalyst}

The effect of time on stream on the performance of the $1 \% \mathrm{Pt} / \mathrm{Al}_{2} \mathrm{O}_{3}$ catalyst was studied at $600{ }^{\circ} \mathrm{C}$ for 16 hours on stream. The materials are given in Section 3.2.4.1 and methodology is given in Section 3.2.4.4.

Figure 5.2 shows the time-on-stream behavior of $1 \% \mathrm{Pt} / \mathrm{Al}_{2} \mathrm{O}_{3}$ catalyst for the partial oxidation of propane at $600{ }^{\circ} \mathrm{C}$. The initial propane conversion is $50 \%$ and hydrogen selectivity is $36 \%$. Oxygen conversion is always $100 \%$. At $\mathrm{t}=16 \mathrm{hr}$, propane conversion is $46 \%$ and hydrogen selectivity $29 \%$. After $5 \mathrm{hrs}$ of time on stream, the catalyst is very stable. The conversion of propane and selectivities of hydrogen, carbon 
monoxide and carbon dioxide do not change much over the time period. The rate of deactivation was calculated by linear regression of propane conversion to be $0.25 \%$ propane conversion/hr. This indicates that the $1 \% \mathrm{Pt} / \mathrm{Al}_{2} \mathrm{O}_{3}$ catalyst is stable for partial oxidation of propane and not deactivating during the course of reaction.

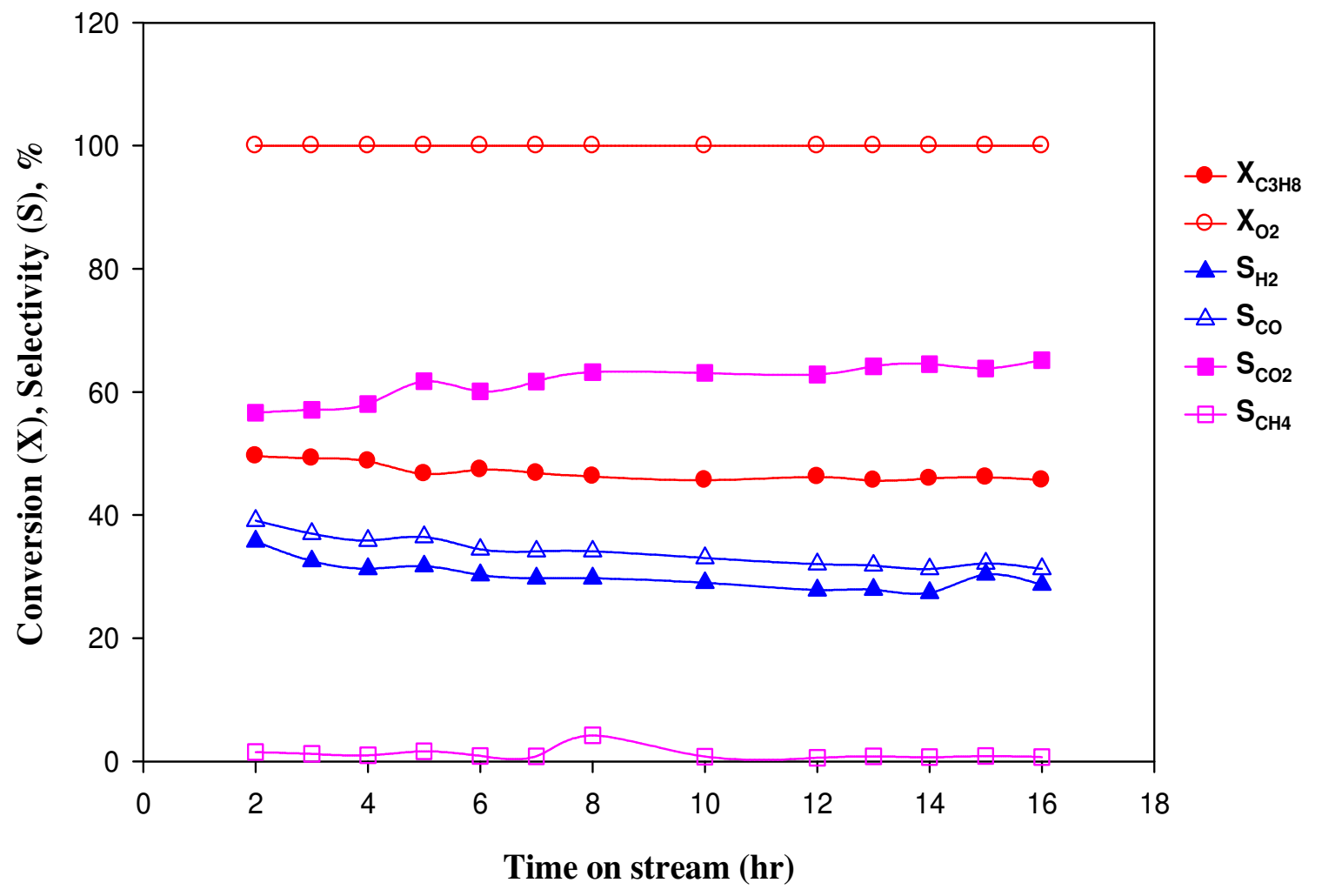

Figure 5.2 Stability of $1 \% \mathrm{Pt}^{-} / \mathrm{Al}_{2} \mathrm{O}_{3}$ for propane activity and product selectivities against time on stream $\left(\mathrm{T}=600{ }^{\circ} \mathrm{C}\right.$, total flow rate $=300 \mathrm{sccm}$ with $90 \%$ inert $)$ 


\subsection{Effect of $\mathrm{O}_{2} / \mathrm{C}_{3} \mathrm{H}_{8}$ ratio}

\subsubsection{Pt/CeO $(\mathrm{C})$ catalyst}

The $1 \% \mathrm{Pt} / \mathrm{CeO}_{2}$ (C) catalyst is studied for the effect of the $\mathrm{O}_{2} / \mathrm{C}_{3} \mathrm{H}_{8}$ ratio. The materials are given in Section 3.2.4.1 and methodology for this reaction is given in Section 3.2.4.5.

Figure 5.3 shows the effect of the $\mathrm{O}_{2} / \mathrm{C}_{3} \mathrm{H}_{8}$ ratio on partial oxidation of propane over $1 \% \mathrm{Pt} / \mathrm{CeO}_{2}$ (C) catalyst. Propane conversion and carbon dioxide selectivity increase as the $\mathrm{O}_{2} / \mathrm{C}_{3} \mathrm{H}_{8}$ ratio increases. The hydrogen and carbon monoxide selectivities decrease with increase in the $\mathrm{O}_{2} / \mathrm{C}_{3} \mathrm{H}_{8}$ ratio.

The stoichiometric ratio for partial oxidation is 1.5 while it equals 5 for total oxidation. Between $\mathrm{O}_{2} / \mathrm{C}_{3} \mathrm{H}_{8}=1.5$ and $\mathrm{O}_{2} / \mathrm{C}_{3} \mathrm{H}_{8}=5$, the selectivities of hydrogen and carbon monoxide decrease, and the selectivity of $\mathrm{CO}_{2}$ increases. This indicates that, as $\mathrm{O}_{2} / \mathrm{C}_{3} \mathrm{H}_{8}$ passes the stoichiometric point for partial oxidation and moves closer to the stoichiometric point for total oxidation, though the propane conversion is increasing, a small amount of propane is reacting through reforming reactions to form hydrogen and carbon monoxide while most of the propane is reacting through total oxidation to form carbon dioxide. Oxygen conversion is $100 \%$ up to $\mathrm{O}_{2} / \mathrm{C}_{3} \mathrm{H}_{8}=5$ (corresponds to complete combustion). Above $\mathrm{O}_{2} / \mathrm{C}_{3} \mathrm{H}_{8}=5$, there is excess oxygen present, and it remains unreacted. Hence the conversion decreases.

At values of $\mathrm{O}_{2} / \mathrm{C}_{3} \mathrm{H}_{8}$ greater than 5 , all the reacted propane is converted into carbon dioxide. Below $\mathrm{O}_{2} / \mathrm{C}_{3} \mathrm{H}_{8}=1.5$, conversion of propane is very low but very high hydrogen and carbon monoxide selectivities are obtained with very low carbon dioxide selectivity. The maximum hydrogen selectivity $\left(94 \%\right.$ ) is obtained at $\mathrm{O}_{2} / \mathrm{C}_{3} \mathrm{H}_{8}=0.5$ but conversion of propane is very low, $28 \%$, under these conditions. The optimum $\mathrm{O}_{2} / \mathrm{C}_{3} \mathrm{H}_{8}$ ratio is probably around 2 for high hydrogen selectivity and high propane conversion. At $\mathrm{O}_{2} / \mathrm{C}_{3} \mathrm{H}_{8}$ values greater than 5, hydrogen, carbon monoxide and methane are not observed. 


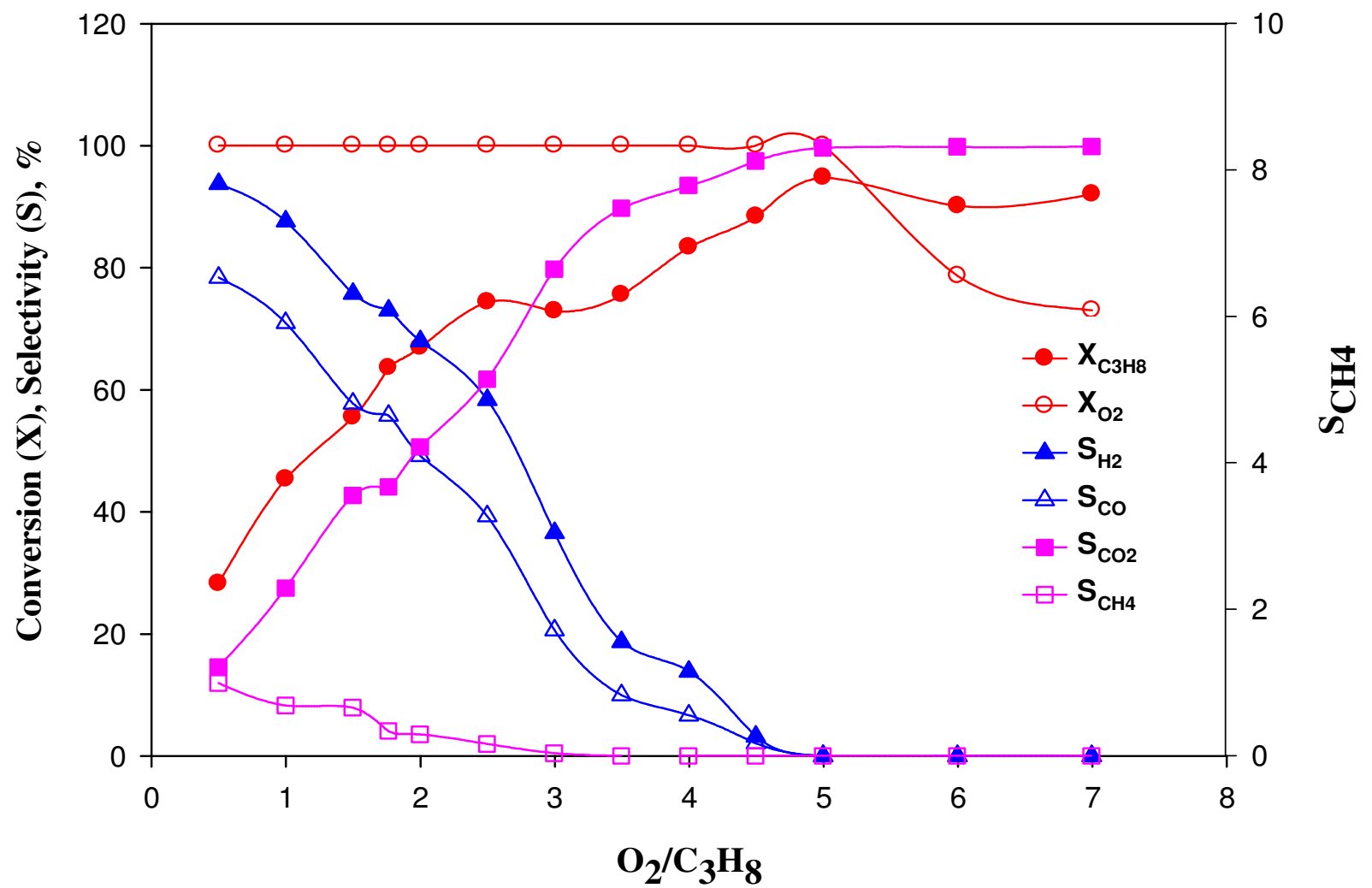

Figure 5.3 Effect of $\mathrm{O}_{2} / \mathrm{C}_{3} \mathrm{H}_{8}$ ratio on partial oxidation of propane on $1 \% \mathrm{Pt} / \mathrm{CeO}_{2}(\mathrm{C})$ catalyst $\left(\mathrm{T}=675^{\circ} \mathrm{C}\right.$, total flow rate $=300 \mathrm{scc} / \mathrm{min}$ with $90 \%$ inert $)$

\subsubsection{Pt/ $/ \mathrm{Al}_{2} \mathrm{O}_{3}$ catalyst}

The materials are given in Section 3.2.4.1 and methodology for this reaction is given in Section 3.2.4.5.

Figure 5.4 shows the effect of the $\mathrm{O}_{2} / \mathrm{C}_{3} \mathrm{H}_{8}$ ratio on partial oxidation of propane over the $1 \% \mathrm{Pt} / \mathrm{Al}_{2} \mathrm{O}_{3}$ catalyst. Similar behavior is observed for $1 \% \mathrm{Pt} / \mathrm{Al}_{2} \mathrm{O}_{3}$ as it was observed for $1 \% \mathrm{Pt} / \mathrm{CeO}_{2}(\mathrm{C})$ catalyst. Propane conversion increases as $\mathrm{O}_{2} / \mathrm{C}_{3} \mathrm{H}_{8}$ increases. The selectivities of hydrogen and carbon monoxide decrease, and the selectivity of $\mathrm{CO}_{2}$ increases, with increase in the $\mathrm{O}_{2} / \mathrm{C}_{3} \mathrm{H}_{8}$ ratio. Oxygen conversion is $100 \%$ up to $\mathrm{O}_{2} / \mathrm{C}_{3} \mathrm{H}_{8}=$ 5 (corresponds to complete combustion) and it decreases for higher values. At values of $\mathrm{O}_{2} / \mathrm{C}_{3} \mathrm{H}_{8}$ greater than 5 , all the reacted propane is converted into carbon dioxide. 
The maximum hydrogen selectivity $(81 \%)$ is obtained at $\mathrm{O}_{2} / \mathrm{C}_{3} \mathrm{H}_{8}=0.5$ but conversion of propane is very low, $22 \%$, under these conditions. The optimum $\mathrm{O}_{2} / \mathrm{C}_{3} \mathrm{H}_{8}$ ratio is probably around 2 for high hydrogen selectivity and high propane conversion. At $\mathrm{O}_{2} / \mathrm{C}_{3} \mathrm{H}_{8}$ values greater than 5 , hydrogen, carbon monoxide and methane are not observed. The results confirm the observation made for $1 \% \mathrm{Pt} / \mathrm{CeO}_{2}$, that the optimum $\mathrm{O}_{2} / \mathrm{C}_{3} \mathrm{H}_{8}$ ratio is around 2 for high conversion of propane and high selectivity of hydrogen.

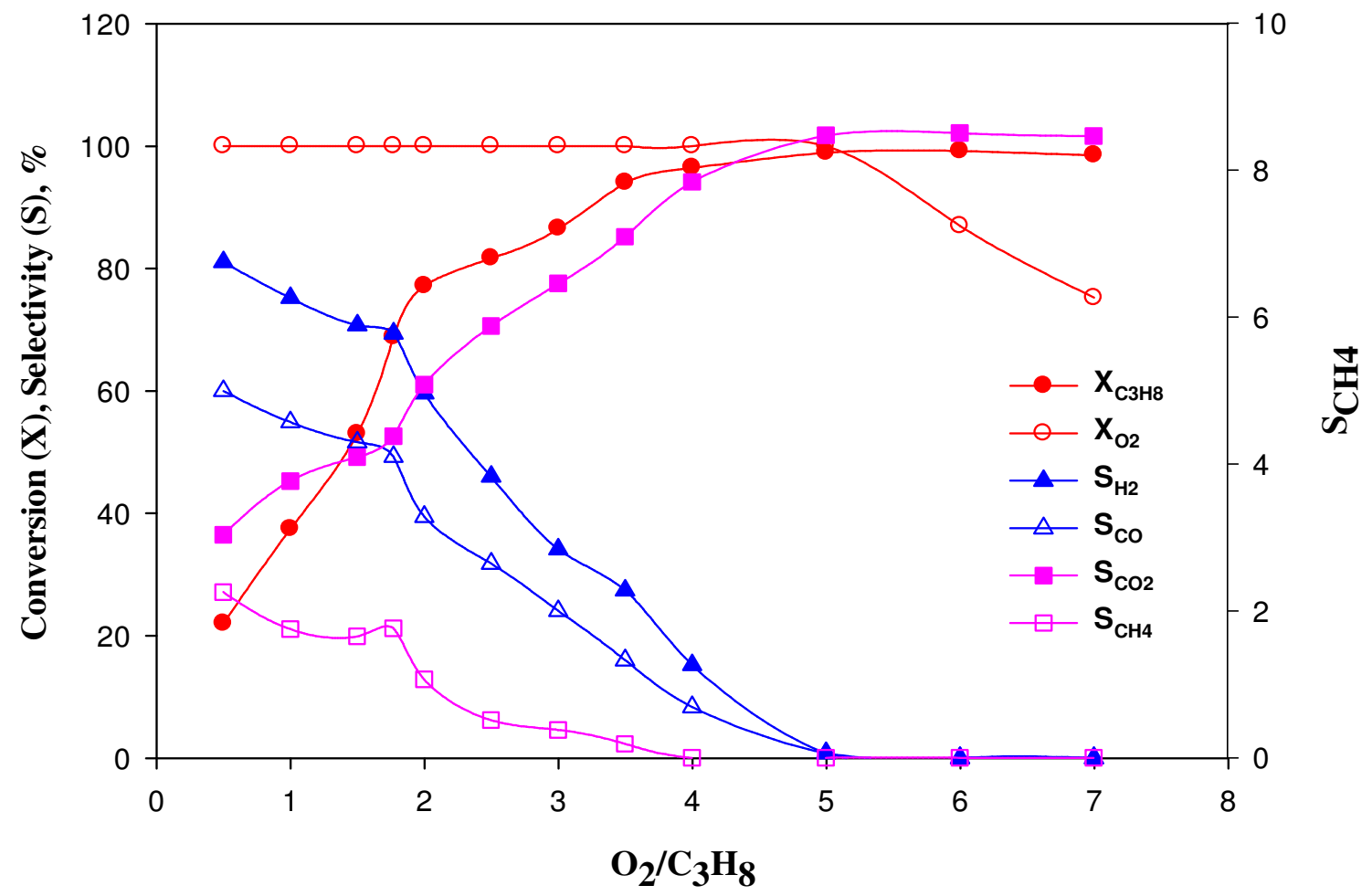

Figure 5.4 Effect of $\mathrm{O}_{2} / \mathrm{C}_{3} \mathrm{H}_{8}$ ratio on partial oxidation of propane on $1 \% \mathrm{Pt} / \mathrm{Al}_{2} \mathrm{O}_{3}$ catalyst $\left(\mathrm{T}=675^{\circ} \mathrm{C}\right.$, total flow rate $=300 \mathrm{scc} / \mathrm{min}$ with $90 \%$ inert $)$ 


\subsection{Summary}

The effect of time on stream on the performance of $1 \% \mathrm{Pt} / \mathrm{CeO}_{2}$ (C) and $1 \%$ $\mathrm{Pt} / \mathrm{Al}_{2} \mathrm{O}_{3}$ show that both the catalysts are stable, with deactivation rates of $0.28 \%$ and 0.25 $\%$ propane conversion/hr respectively.

The effect of the $\mathrm{O}_{2} / \mathrm{C}_{3} \mathrm{H}_{8}$ ratio on partial oxidation of propane for $1 \% \mathrm{Pt} / \mathrm{CeO}_{2}(\mathrm{C})$ and $1 \% \mathrm{Pt} / \mathrm{Al}_{2} \mathrm{O}_{3}$ show that the conversion of propane increases and the hydrogen selectivity decreases with increase in the $\mathrm{O}_{2} / \mathrm{C}_{3} \mathrm{H}_{8}$ ratio. The optimum ratio is probably around 2 for high propane conversion and high hydrogen selectivity. 


\section{Chapter 6: Effect of Flow Rate on Partial Oxidation of Propane}

\subsection{Introduction}

The effect of temperature on partial oxidation has been studied by many researchers. Partial oxidation, steam reforming, water gas shift reaction and dry reforming are the proposed reactions responsible for hydrogen production at high temperatures. Very few studies have been done to study the effect of flow rate on partial oxidation. Hence the effect of flow rate is studied for $1 \% \mathrm{Pt} / \mathrm{CeO}_{2}(\mathrm{C})$ and $1 \% \mathrm{Pt} / \mathrm{Al}_{2} \mathrm{O}_{3}$ catalysts to understand the partial oxidation reaction. This reaction is carried out at very low catalyst loadings and low temperature $\left(600^{\circ} \mathrm{C}\right)$ so that the reactor can be studied as a differential reactor and the reaction scheme can be understood. Partial oxidation is also carried out on $\mathrm{CeO}_{2}(\mathrm{C})$ and $\gamma$ $\mathrm{Al}_{2} \mathrm{O}_{3}$ supports to see if the support has any activity towards this reaction. Finally, dry reforming of propane is carried out to understand if this has any contribution to the overall reaction set.

Prior to catalytic testing, a blank reaction is carried out in a quartz reactor. Table 6.1 shows the results for the blank reaction. There is only $3 \%$ conversion of propane and all the reacted propane is converted into carbon dioxide.

Table 6.1 Effect of temperature on the activity of the quartz reactor for partial oxidation of propane (total flow rate $=300 \mathrm{scc} / \mathrm{min}, \mathrm{O}_{2} / \mathrm{C}_{3} \mathrm{H}_{8}=1.78$ )

\begin{tabular}{|c|c|c|c|c|c|}
\hline $\begin{array}{c}\text { Temperature } \\
(\boldsymbol{0} \mathbf{C})\end{array}$ & $\mathbf{X}_{\mathbf{C 3 H 8}}, \boldsymbol{\%}$ & $\mathbf{X}_{\mathbf{O 2}}, \boldsymbol{\%}$ & $\mathbf{S}_{\mathbf{H 2}}, \boldsymbol{\%}$ & $\mathbf{S}_{\mathbf{C O}}, \boldsymbol{\%}$ & $\mathbf{S}_{\mathbf{C O 2}}, \boldsymbol{\%}$ \\
\hline 300 & 0 & 0 & 0 & 0 & 0 \\
\hline 400 & 0 & 0 & 0 & 0 & 0 \\
\hline 500 & 0.7 & 2.6 & 0 & 0 & 99.2 \\
\hline 600 & 2.8 & 7.9 & 0 & 0 & 100 \\
\hline 700 & 6.5 & 13.2 & 1.2 & 3.2 & 68.7 \\
\hline 800 & 86.7 & 75.5 & 5.2 & 14.2 & 17.1 \\
\hline
\end{tabular}




\subsection{Study of support for partial oxidation of propane}

Partial oxidation of propane was studied for $\mathrm{CeO}_{2}(\mathrm{C})$ and $\gamma-\mathrm{Al}_{2} \mathrm{O}_{3}$ supports. The materials and methodology are given in Section 3.2.4.6.

Table 6.2 shows results for partial oxidation of propane on the $\mathrm{CeO}_{2}(\mathrm{C})$ and $\gamma$ $\mathrm{Al}_{2} \mathrm{O}_{3}$ supports. For the $\mathrm{CeO}_{2}$ (C) support, as the flow rate decreases, the conversion of propane and of oxygen increase. Conversion of oxygen is $100 \%$ at the lower flow rate (50 scc/min). The reaction on $\mathrm{CeO}_{2}$ (C) support gives $17.39 \%$ and $35.81 \%$ propane conversion at $300 \mathrm{scc} / \mathrm{min}$ and $50 \mathrm{scc} / \mathrm{min}$ respectively. Hydrogen selectivity is less than 3 $\%$, independent of flow rate. There is no carbon monoxide formation; the largest part of the reacted propane forms carbon dioxide. The FID detector shows peaks for propylene and methane. The results for the blank reaction indicate that the reactor is not active at $600{ }^{\circ} \mathrm{C}$ and the activity for total oxidation of propane is coming from the support.

Propane is converted into carbon dioxide and water with no carbon monoxide production for partial oxidation of propane on support alone. Similar results are observed with the alumina support. Conversion of propane and oxygen increases with decrease in the flow rate. Propane is converted into carbon dioxide and water. Hydrogen selectivity is very low. Some amount of carbon monoxide is observed at $50 \mathrm{scc} / \mathrm{min}$, but it is very low. The alumina support shows less conversion of propane and oxygen (as compared to the ceria support) at both high and low flow rates. This indicates that the ceria support is more active for total oxidation than the alumina support.

For both the supports, hydrogen formation can be explained by the reaction of propane decomposition into propylene and hydrogen which is shown below.

$$
\mathrm{C}_{3} \mathrm{H}_{8} \rightarrow \mathrm{C}_{3} \mathrm{H}_{6}+\mathrm{H}_{2}
$$

Equation 6.1 
The results for partial oxidation of propane for the $\mathrm{CeO}_{2}(\mathrm{C})$ and $\gamma-\mathrm{Al}_{2} \mathrm{O}_{3}$ support show that the supports are active for total oxidation of propane but not for reforming reactions of propane to produce hydrogen.

Table 6.2 Partial oxidation of propane on $\mathrm{CeO}_{2}$ (C) and $\gamma-\mathrm{Al}_{2} \mathrm{O}_{3}$ supports $\left(\right.$ Temperature $=600{ }^{\circ} \mathrm{C}, \mathrm{O}_{2} / \mathrm{C}_{3} \mathrm{H}_{8}=1.78$, amount of catalyst $\left.=0.02 \mathrm{~g}\right)$

\begin{tabular}{|c|c|c|c|c|}
\hline Catalyst & \multicolumn{2}{|c|}{$\mathrm{CeO}_{2}(\mathrm{C})$} & \multicolumn{2}{|c|}{$\gamma-\mathrm{Al}_{2} \mathbf{O}_{3}$} \\
\hline $\begin{array}{l}\text { Total flow } \\
\text { (scc/min) }\end{array}$ & 300 & 50 & 300 & 50 \\
\hline $\mathbf{X}_{\mathrm{C3H8}}, \%$ & 17.4 & 35.8 & 5.9 & 26.8 \\
\hline $\mathbf{X}_{\mathbf{O} 2}, \%$ & 41.2 & 100 & 15.9 & 68.0 \\
\hline $\mathbf{S}_{\mathrm{H} 2}, \%$ & 2.6 & 1.5 & 2.3 & 2.9 \\
\hline $\mathbf{S}_{\mathrm{CO}, \%} \%$ & 0 & 0 & 0 & 5.7 \\
\hline $\mathrm{S}_{\mathrm{CO} 2}, \%$ & 81.3 & 90.8 & 87.3 & 90.4 \\
\hline
\end{tabular}




\subsection{Effect of flow rate}

\subsection{1 $1 \% \mathrm{Pt} / \mathrm{CeO}_{2}(\mathrm{C})$ Catalyst}

The effect of flow was studied for $0.01 \mathrm{~g}$ and $0.02 \mathrm{~g}$ of $1 \% \mathrm{Pt} / \mathrm{CeO}_{2}(\mathrm{C})$ catalyst. The reaction was carried out in the quartz reactor at $600{ }^{\circ} \mathrm{C}$. The materials and methodology are given in Section 3.2.4.7.

Figure 6.1 shows the effect of flow rate on catalyst activity and selectivity for partial oxidation of propane over $1 \% \mathrm{Pt} / \mathrm{CeO}_{2}(\mathrm{C})$. The results are shown for both $0.01 \mathrm{~g}$ and $0.02 \mathrm{~g}$ loading. Oxygen outlet flow rates are not shown in the graph, as oxygen is completely consumed at all flow rates and all catalyst loadings used. From Figure 6.1, the outlet flow rate of propane at $0.02 \mathrm{~g}$ is less than that at $0.01 \mathrm{~g}$ at all the flow rates. This indicates that, as expected, the conversion of propane increases with increase in catalyst weight at all flow rates. Similarly, the production of hydrogen increases with increase in catalyst weight at all flow rates. The conversion of propane does not change much with respect to total inlet flow rate, which indicates that the reaction is not mass transfer controlled under these operating conditions.

All the total oxidation of propane takes place in the first half of the reactor $(0.01 \mathrm{~g})$, as all the oxygen is consumed at $0.01 \mathrm{~g}$ catalyst loading itself. For the second half of the reactor containing $0.01 \mathrm{~g}$ catalyst, the unreacted propane undergoes reforming reactions such as steam reforming and dry reforming by reacting with the products formed in total oxidation.

Further, the production of carbon dioxide increases with increase in catalyst weight at all the flow rates. Finally, the outlet flow rate of carbon monoxide at $0.02 \mathrm{~g}$ is almost the same as the outlet flow rate at 0.01 for lower flow rates, i.e. 50, 100 and $200 \mathrm{scc} / \mathrm{min}$. For the higher flow rates, i.e. $300 \mathrm{scc} / \mathrm{min}$ and $400 \mathrm{scc} / \mathrm{min}$, the outlet flow rate of carbon monoxide at $0.02 \mathrm{~g}$ is less that that at $0.01 \mathrm{~g}$. This shows that, at the lower space times (higher space velocities), the carbon monoxide formed at $0.01 \mathrm{~g}$ loading is reacting further 
as the amount of catalyst increases. Most probably this overall loss of $\mathrm{CO}$ and overall gain in $\mathrm{CO}_{2}$ is due to consumption of carbon monoxide through water gas shift reaction (Equation 2.6).

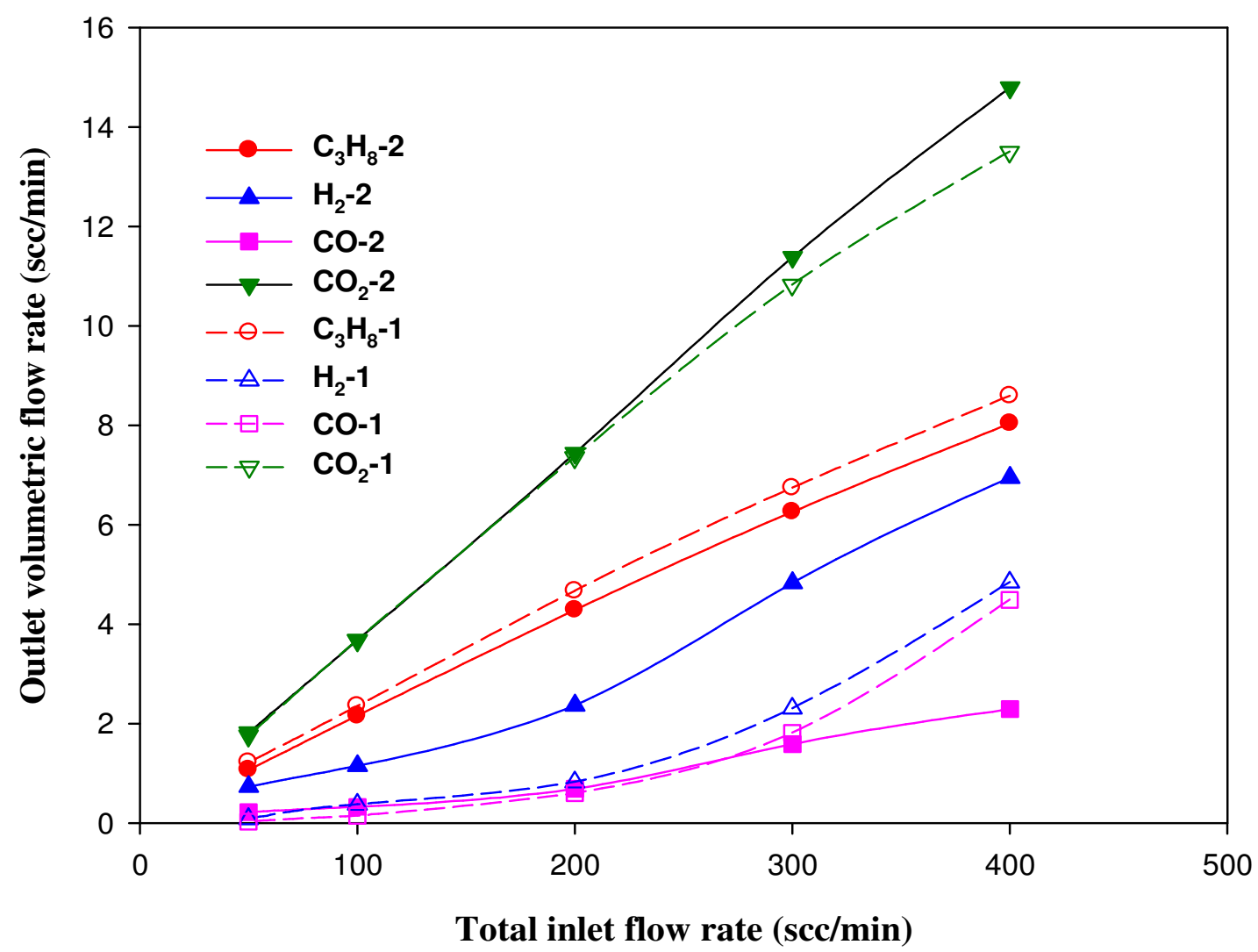

Figure 6.1 Effect of flow rate on $1 \% \mathrm{Pt} / \mathrm{CeO}_{2}(\mathrm{C})$ catalyst activity and product distribution for partial oxidation of propane $\left(T=600^{\circ} \mathrm{C}, \mathrm{O}_{2} / \mathrm{C}_{3} \mathrm{H}_{8}=1.77,90 \%\right.$ inert; 1- $0.01 \mathrm{~g}$ and 2-0.02 g catalyst weight)

\subsection{2 $1 \% \mathrm{Pt}_{/} / \mathrm{Al}_{2} \mathrm{O}_{3}$ Catalyst}

As for the $1 \% \mathrm{Pt} / \mathrm{CeO}_{2}$ (C) catalyst, the effect of flow was studied for $0.01 \mathrm{~g}$ and $0.02 \mathrm{~g}$ of $1 \% \mathrm{Pt} / \mathrm{Al}_{2} \mathrm{O}_{3}$ catalyst. The reaction was carried out in the quartz reactor at $600^{\circ}$ C. The materials and methodology are given in Section 3.2.4.7.

Figure 6.2 shows the effect of flow rate on catalyst activity and selectivity for partial oxidation of propane over $1 \% \mathrm{Pt} / \mathrm{Al}_{2} \mathrm{O}_{3}$. The results are shown for both $0.01 \mathrm{~g}$ and $0.02 \mathrm{~g}$ loading. Figure 6.2 compares conversion of propane and product selectivities at catalyst weight $0.01 \mathrm{~g}$ and $0.02 \mathrm{~g}$, similar to Figure 6.1 for $1 \% \mathrm{Pt} / \mathrm{CeO}_{2}(\mathrm{C})$ catalyst. 
The behaviors of oxygen, propane and hydrogen are qualitatively similar in Figures 6.1 and 6.2. Production of carbon monoxide increases with increase in catalyst weight at all the flow rates. However, at higher flow rates such as $300 \mathrm{scc} / \mathrm{min}$ and $400 \mathrm{scc} / \mathrm{min}$, the outlet flow rate of carbon dioxide at $0.02 \mathrm{~g}$ is less that the outlet flow rate at $0.01 \mathrm{~g}$. This indicates that the carbon dioxide formed at $0.01 \mathrm{~g}$ loading is reacting further as the catalyst loading increases.

Carbon dioxide could be getting consumed by dry reforming (Equation 2.7) or by the Reverse Boudouard reaction (Equation 2.8) or by both. Accordingly, experiments were carried out to see if the $1 \% \mathrm{Pt} / \mathrm{CeO}_{2}(\mathrm{C})$ and $1 \% \mathrm{Pt} / \mathrm{Al}_{2} \mathrm{O}_{3}$ catalysts are active for dry reforming. These results are reported in the next section.

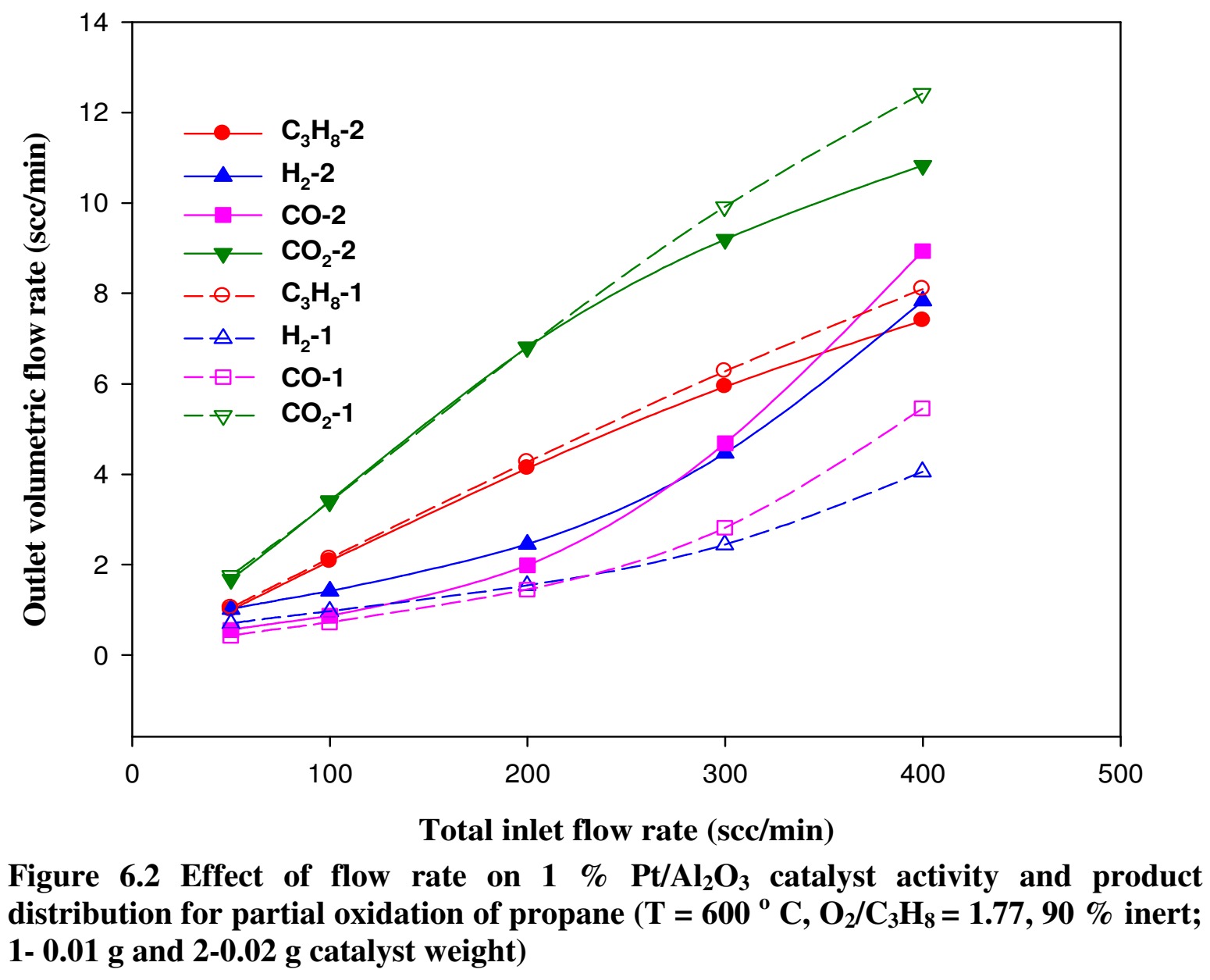




\subsection{Dry reforming of propane}

The argument was made in the previous section which dealt with effect of flow rate on partial oxidation of propane that the propane reacts with total oxidation first and then the unreacted propane undergoes reforming reactions such as steam and dry reforming. Accordingly, dry reforming of propane is carried out over $1 \% \mathrm{Pt} / \mathrm{CeO}_{2}(\mathrm{C})$ and $1 \%$ $\mathrm{Pt} / \mathrm{Al}_{2} \mathrm{O}_{3}$ catalysts. The materials and methodology are given in Section 3.2.4.8.

The partial oxidation of propane was carried out over $1 \% \mathrm{Pt} / \mathrm{CeO}_{2}(\mathrm{C})$ and $1 \%$ $\mathrm{Pt} / \mathrm{Al}_{2} \mathrm{O}_{3}$ catalysts for a few flow rates before carrying out the dry reforming reaction. Then the dry reforming reaction is carried out, varying the total flow rate from $300 \mathrm{scc} / \mathrm{min}$ to $100 \mathrm{scc} / \mathrm{min}$. Table 6.3 shows the results for dry reforming of propane, compared with those of the partial oxidation of propane at same total flow rate.

The catalysts were active for the partial oxidation reaction. The results for dry reforming of propane on $1 \% \mathrm{Pt} / \mathrm{Al}_{2} \mathrm{O}_{3}$ show a conversion of propane of only $2-3 \%$. Conversion of carbon dioxide is also very low, around $2 \%$. The outlet flow rates of hydrogen and carbon monoxide are also very low, as compared to those obtained in partial oxidation. Recall that the blank test carried out for the quartz reactor alone at $600{ }^{\circ} \mathrm{C}$ gives $2 \%$ propane conversion, with all the reacted propane converted into carbon dioxide and water with no carbon monoxide and hydrogen production. These results confirm that the carbon monoxide and hydrogen produced in the dry reforming run are due to the presence of the catalyst and not because of activity of the reactor.

Similar results are obtained for dry reforming over $1 \% \mathrm{Pt} / \mathrm{CeO}_{2}$ (C) catalyst. Conversions of propane and carbon dioxide over $1 \% \mathrm{Pt} / \mathrm{CeO}_{2}(\mathrm{C})$ are slightly higher than those on $1 \% \mathrm{Pt} / \mathrm{Al}_{2} \mathrm{O}_{3}$. Prior studies (Pantu and Gavalas, 2002) show that dry reforming of methane over noble metals supported on cerium oxide is faster than over the metals supported on aluminum oxide. 
The results of Table 6.3 for dry reforming of propane on $1 \% \mathrm{Pt}_{\mathrm{Al}} \mathrm{O}_{3}$ and $1 \%$ $\mathrm{Pt} / \mathrm{CeO}_{2}(\mathrm{C})$, indicate that dry reforming is not a major component of reforming reactions over either catalyst, and can be neglected.

Table 6.3 Comparison of dry reforming and partial oxidation of propane (Temperature $=600{ }^{\circ} \mathrm{C}$, Catalyst amount $=0.02$ g, Dry Reforming: $\mathrm{CO}_{2} / \mathrm{C}_{3} \mathrm{H}_{8}=3,86$ $\%$ inert $\left(\mathrm{N}_{2}+\mathrm{Ar}\right)$; Partial Oxidation: $\mathrm{O}_{2} / \mathrm{C}_{3} \mathrm{H}_{8}=1.78,90 \%$ inert $\left.\left(\mathrm{N}_{2}+\mathrm{Ar}\right)\right)$

\begin{tabular}{|c|c|c|c|c|c|c|c|c|}
\hline \multicolumn{2}{|c|}{ Reaction } & \multicolumn{4}{|c|}{ Dry Reforming } & \multicolumn{3}{|c|}{ Partial Oxidation } \\
\hline Catalyst & $\begin{array}{c}\text { Total } \\
\text { flow rate } \\
\text { (scc/min) }\end{array}$ & $\mathbf{X}_{\mathrm{C} 3 \mathrm{H} 8}$ & $\mathrm{X}_{\mathrm{CO} 2}$ & $\begin{array}{c}\mathbf{H}_{2} \\
\text { (scc/min) }\end{array}$ & $\begin{array}{c}\mathrm{CO} \\
\text { (scc/min) }\end{array}$ & $\mathbf{X}_{\mathrm{C} 3 \mathrm{H} 8}$ & $\begin{array}{c}\mathbf{H}_{2} \\
\text { (scc/min) }\end{array}$ & $\begin{array}{c}\mathrm{CO} \\
\text { (scc/min) }\end{array}$ \\
\hline \multirow{3}{*}{$1 \% \mathrm{Pt} / \mathrm{Al}_{2} \mathrm{O}_{3}$} & 300 & 2.07 & 2.58 & 0.04 & 0.28 & 46.16 & 4.92 & 4.98 \\
\hline & 200 & 2.09 & 1.14 & 0.03 & 0.29 & - & - & - \\
\hline & 100 & 3.51 & 1.85 & 0.02 & 0.19 & 43.11 & 1.6 & 0.78 \\
\hline \multirow{3}{*}{$\begin{array}{c}1 \% \underset{\text { Pt/CeO }}{ } \\
\text { (C) }\end{array}$} & 300 & 3.85 & 4.46 & 0.12 & 1.39 & 41.12 & 4.43 & 1.38 \\
\hline & 200 & 4.43 & 4.78 & 0.10 & 1.06 & - & - & - \\
\hline & 100 & 5.16 & 4.84 & 0.09 & 0.79 & 42.12 & 1.3 & 0.4 \\
\hline
\end{tabular}




\subsection{Reaction scheme}

The effect of flow rate and catalyst loading indicate that total oxidation of propane is occurring first,

$$
\mathrm{C}_{3} \mathrm{H}_{8}+5 \mathrm{O}_{2} \rightarrow 3 \mathrm{CO}_{2}+4 \mathrm{H}_{2} \mathrm{O} \quad \text { Equation } 6.2
$$

and unreacted propane is then reacting with steam to form hydrogen and carbon monoxide (steam reforming)

$$
\mathrm{C}_{3} \mathrm{H}_{8}+3 \mathrm{H}_{2} \mathrm{O} \rightarrow 3 \mathrm{CO}+7 \mathrm{H}_{2} \quad \text { Equation } 6.3
$$

The results of the previous section indicate that dry reforming is not occurring. For $1 \% \mathrm{Pt} / \mathrm{CeO}_{2}(\mathrm{C})$, at high flow rates, carbon monoxide is consumed and carbon dioxide production rate is increasing with catalyst loading. However, for $1 \% \mathrm{Pt} / \mathrm{Al}_{2} \mathrm{O}_{3}$, at high flow rates, carbon dioxide is consumed and carbon monoxide production rate increases with catalyst loading. To explain this difference in the behavior of two catalysts, two reactions are considered.

The first is the water gas shift reaction, in which carbon monoxide reacts with steam to form carbon dioxide and hydrogen.

$$
\mathrm{CO}+\mathrm{H}_{2} \mathrm{O} \rightarrow \mathrm{CO}_{2}+\mathrm{H}_{2} \quad \text { Equation } 6.4
$$

The second is the reverse Boudouard reaction $(\mathrm{RB})$, in which carbon dioxide reacts with carbon formed by dissociation of propane to form carbon monoxide.

$$
\begin{array}{ll}
\mathrm{C}+\mathrm{CO}_{2} \rightarrow 2 \mathrm{CO} & \text { Equation } 6.5
\end{array}
$$

For each of these reactions, we compare experimentally determined outlet conditions with equilibrium values, to determine whether the reaction is far from equilibrium, near (or at) equilibrium, or proceeding in the reverse direction. 


\subsubsection{Calculation of Activity Ratio}

For the water gas shift reaction, we define the activity ratio, $\mathrm{J}_{\mathrm{WGS}}$, the ratio of activities of products to activities of reactants, (Balzhiser and Samuels, 1972) as:

$$
J_{W G S}=\frac{a_{\mathrm{CO} 2} \times a_{\mathrm{H} 2}}{a_{\mathrm{CO}} \times a_{\mathrm{H} 2 \mathrm{O}}}
$$

Equation 6.6

where $a_{I}$ is the activity of species I. This ratio can be approximated as:

$$
J_{W G S}=\frac{p_{C O 2} \times p_{H 2}}{p_{C O} \times p_{H 2 O}}
$$

where $p_{I}$ is partial pressure of species I, in atm. Hence $J_{W G S}$ can be calculated from reactor exit stream compositions corresponding to entry flow rate.

Further, the equilibrium constant for the Water Gas Shift reaction, $K_{W G S}$, can be calculated from thermodynamic parameters as:

$$
K_{W G S}=\exp \left(-\frac{\Delta G_{W G S}^{o}}{R T}\right)
$$

Equation 6.8

where $\Delta G_{W G S}^{o}$ is the standard state free energy change on reaction, $R$ is the universal gas constant and $T$ is the temperature. $K_{W G S}$ for temperatures other than $25{ }^{\circ} \mathrm{C}$ can be calculated from the chart of $K$ against temperature which is given for standard reactions (Sandler, 1999).

If $J_{W G S}<K_{W G S}$, then the water gas shift reaction will go in the forward direction. On the other hand, if $J_{W G S}>K_{W G S}$, then the water gas shift reaction will go in the reverse direction. 
So by calculating the activity ratio $J_{W G S}$ and comparing with $K_{W G S}$, the direction of the reaction can be determined for the different flow rates.

Similarly $J_{R B}$ can be approximated as:

$$
J_{R B}=\frac{\left(a_{C O}\right)^{2}}{a_{\mathrm{CO}_{2}} \times a_{C}}=\frac{\left(p_{C O}\right)^{2}}{p_{\mathrm{CO}_{2}}}
$$

$K_{R B}$ is given by

$$
K_{R B}=\exp \left(-\frac{\Delta G_{R B}^{o}}{R T}\right)
$$

and $J_{R B}$ and $K_{R B}$ can be compared to find the direction for the reverse Boudouard reaction.

The values of $K_{W G S}$ and $K_{R B}$ at $600^{\circ} \mathrm{C}$ are:

$$
\begin{aligned}
& K_{W G S}=2.82 \\
& K_{R B}=0.089
\end{aligned}
$$

Equation 6.11

Equation 6.12

\subsubsection{Role of Water Gas Shift and Reverse Boudouard Reactions}

The studies for effect of flow rate and catalyst loading indicate that, at higher flow rates, there is an overall loss in $\mathrm{CO}$ production and overall gain in $\mathrm{CO}_{2}$ production for $1 \%$ $\mathrm{Pt} / \mathrm{CeO}_{2}(\mathrm{C})$, whereas there is an overall loss in $\mathrm{CO}_{2}$ production and overall gain in $\mathrm{CO}$ production for $1 \% \mathrm{Pt} / \mathrm{Al}_{2} \mathrm{O}_{3}$. To explain this behavior, we put forward a hypothesis that both water gas shift and reverse Boudouard reaction are taking place on both $1 \% \mathrm{Pt} / \mathrm{CeO}_{2}$ (C) and $1 \% \mathrm{Pt} / \mathrm{Al}_{2} \mathrm{O}_{3}$ catalysts.

For the $1 \% \mathrm{Pt} / \mathrm{CeO}_{2}(\mathrm{C})$ catalyst, the rate of carbon monoxide consumption by the water gas shift reaction is higher than the rate of production of carbon monoxide by the reverse Boudouard reaction and the rate of formation of carbon dioxide by water gas shift is higher than the rate of consumption of carbon dioxide by the reverse Boudouard reaction. 
Hence there is an overall increase in carbon dioxide production and an overall decrease in carbon monoxide production with increase in catalyst loading. Water gas shift is faster than reverse Boudouard reaction since ceria is known to promote water gas shift reaction (Pantu and Gavalas, 2002). Here the water gas shift reaction dominates over reverse Boudouard reaction.

On the other hand, for the $1 \% \mathrm{Pt} / \mathrm{Al}_{2} \mathrm{O}_{3}$ catalyst, the rate of carbon dioxide consumption by the reverse Boudouard reaction is higher than the rate of production of carbon dioxide by water gas shift reaction, and the rate of formation of carbon monoxide by the reverse Boudouard reaction is higher than the rate of consumption of carbon monoxide by water gas shift. Hence there is an overall increase in carbon monoxide production and an overall decrease in carbon dioxide production with increase in catalyst loading. Here the reverse Boudouard reaction dominates over water gas shift reaction.

\subsubsection{Comparison for ceria-and-alumina supported catalysts}

Figure 6.3 gives activity ratios for water gas shift reaction (Equation 6.4 ) for $1 \%$ $\mathrm{Pt} / \mathrm{CeO}_{2}$ and $1 \% \mathrm{Pt} / \mathrm{Al}_{2} \mathrm{O}_{3}$ catalysts. Similarly Figure 6.4 gives activity ratios for reverse Boudouard reaction (Equation 6.5) for $1 \% \mathrm{Pt} / \mathrm{CeO}_{2}$ and $1 \% \mathrm{Pt} / \mathrm{Al}_{2} \mathrm{O}_{3}$ catalysts. Values of $K_{W G S}$ and $K_{R B}$ are also shown.

From Figure 6.3, the activity ratios are less than $K_{W G S}$ at all flow rates for $0.01 \mathrm{~g}$ catalyst loading for $1 \% \mathrm{Pt} / \mathrm{Al}_{2} \mathrm{O}_{3}$ catalyst. Hence the water gas shift is far from equilibrium and the reaction takes place only in the forward direction. The activity ratios at $0.02 \mathrm{~g}$ are generally higher than those at $0.01 \mathrm{~g}$ catalyst loading, and are generally closer to, but still less than, the value of $K_{W G S}$. This indicates that reaction is closer to equilibrium, but still takes place in the forward direction.

Activity ratios for $0.01 \mathrm{~g}$ of $1 \% \mathrm{Pt} / \mathrm{CeO}_{2}(\mathrm{C})$ are larger than those for $0.01 \mathrm{~g}$ of $1 \%$ $\mathrm{Pt} / \mathrm{Al}_{2} \mathrm{O}_{3}$, but less than $K_{W G S}$. However, for $0.02 \mathrm{~g}$ of $1 \% \mathrm{Pt} / \mathrm{CeO}_{2}(\mathrm{C})$, activity ratios are 
very close to equilibrium constant. Hence water gas shift can be expected to be very close to equilibrium for $0.02 \mathrm{~g}$ of $1 \% \mathrm{Pt} / \mathrm{CeO}_{2}(\mathrm{C})$. These calculations support the argument made before that water gas shift is faster on $1 \% \mathrm{Pt} / \mathrm{CeO}_{2}$ than on $1 \% \mathrm{Pt} / \mathrm{Al}_{2} \mathrm{O}_{3}$ and is very near to equilibrium. For $1 \% \mathrm{Pt} / \mathrm{Al}_{2} \mathrm{O}_{3}$, water gas shift is far from equilibrium.

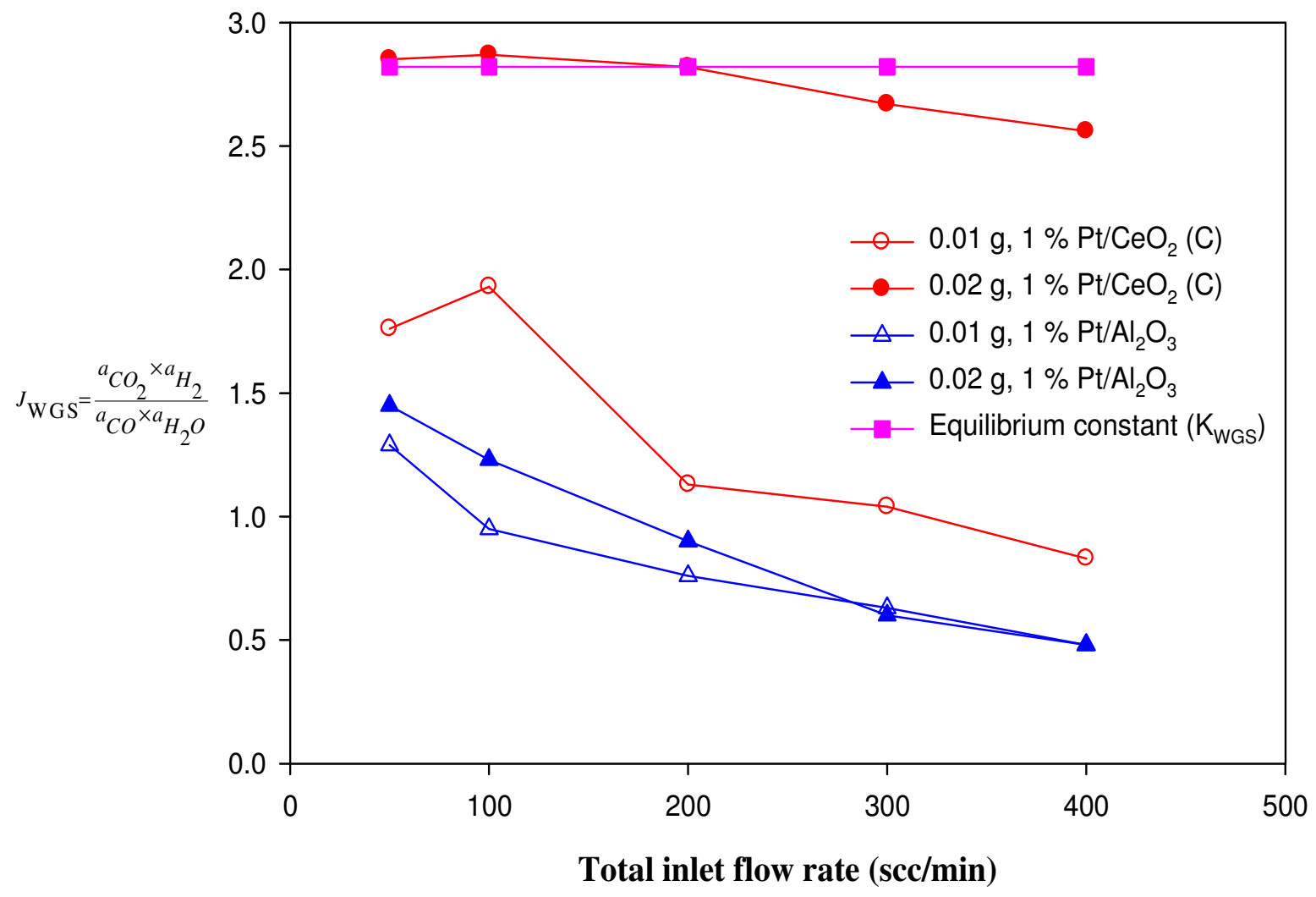

Figure 6.3 Effect of catalyst amount and support on activity ratio $J_{W G S}$ at different flow rates $\left(\mathrm{T}=600{ }^{\circ} \mathrm{C}, \mathrm{O}_{2} / \mathrm{C}_{3} \mathrm{H}_{8}=1.77,90 \%\right.$ inert $)$

From Figure 6.4, the activity ratios are less than $K_{R B}$ at all flow rates for both 0.01 $\mathrm{g}$ and $0.02 \mathrm{~g}$ catalyst loading for $1 \% \mathrm{Pt} / \mathrm{CeO}_{2}$. Hence reverse Boudouard is far from equilibrium and the reaction takes place only in forward direction. The activity ratios at $0.02 \mathrm{~g}$ are generally higher than those at $0.01 \mathrm{~g}$ catalyst loading, but still less than, the value of $K_{R B}$. This indicates that reaction takes place in forward direction. 
Activity ratios for $0.01 \mathrm{~g}$ of $1 \% \mathrm{Pt} / \mathrm{Al}_{2} \mathrm{O}_{3}$ are 10 times larger than those for $0.01 \mathrm{~g}$ of $1 \% \mathrm{Pt} / \mathrm{CeO}_{2}(\mathrm{C})$, but less than $K_{R B}$. However for $0.02 \mathrm{~g}$ of $1 \% \mathrm{Pt} / \mathrm{Al}_{2} \mathrm{O}_{3}$, activity ratios are close to equilibrium constant. Hence the reverse Boudouard can be expected to be very close to equilibrium for $0.02 \mathrm{~g}$ of $1 \% \mathrm{Pt} / \mathrm{Al}_{2} \mathrm{O}_{3}$. These calculations support the argument made before that reverse Boudouard reaction is faster on $1 \% \mathrm{Pt} / \mathrm{Al}_{2} \mathrm{O}_{3}$ than on $1 \%$ $\mathrm{Pt} / \mathrm{CeO}_{2}$ and is near to equilibrium. For $1 \% \mathrm{Pt} / \mathrm{CeO}_{2}(\mathrm{C})$, reverse Boudouard is far from equilibrium.

For the $1 \% \mathrm{Pt} / \mathrm{CeO}_{2}$ catalyst, water gas shift is fast and close to equilibrium, whereas the reverse Boudouard reaction is far from equilibrium. Hence water gas shift dominates over the reverse Boudouard reaction. For $1 \% \mathrm{Pt} / \mathrm{Al}_{2} \mathrm{O}_{3}$ water gas shift is far from equilibrium and the reverse Boudouard reaction is close to equilibrium. Hence the reverse Boudouard reaction dominates over water gas shift reaction.

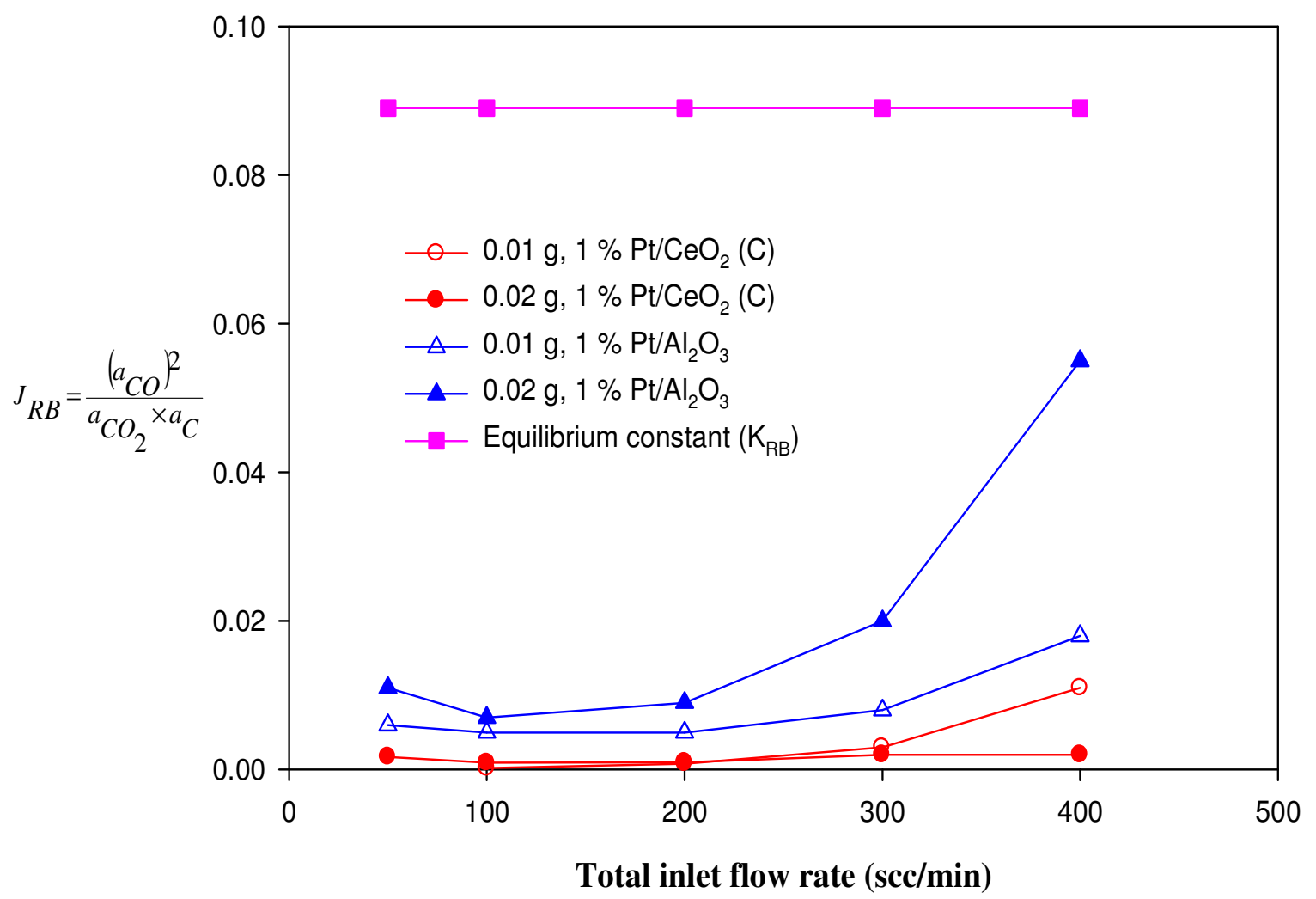

Figure 6.4 Effect of catalyst amount and support on activity ratio $J_{R B}$ at different flow rates $\left(\mathrm{T}=600^{\circ} \mathrm{C}, \mathrm{O}_{2} / \mathrm{C}_{3} \mathrm{H}_{8}=1.77,90 \%\right.$ inert $)$ 


\subsection{Summary}

Study of $\mathrm{CeO}_{2}(\mathrm{C})$ and $\gamma-\mathrm{Al}_{2} \mathrm{O}_{3}$ supports for partial oxidation show that the supports are active for total oxidation of propane to produce carbon dioxide and water. Dry reforming of propane is not a significant reaction for either $1 \% \mathrm{Pt} / \mathrm{Al}_{2} \mathrm{O}_{3}$ or $1 \% \mathrm{Pt} / \mathrm{CeO}_{2}$. Effect of flow rates on $1 \% \mathrm{Pt} / \mathrm{Al}_{2} \mathrm{O}_{3}$ and $1 \% \mathrm{Pt} / \mathrm{CeO}_{2}$ catalysts show that propane first undergoes total oxidation to produce carbon dioxide and water, then unreacted propane undergoes steam reforming to form carbon monoxide and water. The water gas shift reaction dominates over the reverse Boudouard reaction over $1 \% \mathrm{Pt} / \mathrm{CeO}_{2}$ catalyst. Hence there is an overall loss of carbon monoxide production and an overall gain in carbon dioxide production at higher flow rates. On the other hand, the reverse Boudouard reaction dominates over water gas shift over $1 \% \mathrm{Pt} / \mathrm{Al}_{2} \mathrm{O}_{3}$. Hence there is an overall loss in carbon dioxide production and an overall gain in carbon monoxide production at higher flow rates. 


\section{Chapter 7: Summary and Recommendations for Future Work}

\subsection{Summary}

Partial oxidation of propane was studied over $1 \% \mathrm{Pt} / \mathrm{CeO}_{2}(\mathrm{~A}), 1 \% \mathrm{Pt} / \mathrm{CeO}_{2}$ (B) and $1 \% \mathrm{Pt} / \mathrm{CeO}_{2}$ (C) catalysts. The performance of ceria catalysts was compared with $1 \%$ $\mathrm{Pt} / \mathrm{Al}_{2} \mathrm{O}_{3}$ catalyst. All the catalysts are active for partial oxidation reaction.

Ceria supports and catalysts lose surface areas after heat treatment at $900{ }^{\circ} \mathrm{C}$. Among all the ceria supports and the ceria-supported catalysts, $\mathrm{CeO}_{2}$ (B) support and $1 \%$ $\mathrm{Pt} / \mathrm{CeO}_{2}(\mathrm{~B})$ catalysts are the most stable after heat treatment. The $1 \% \mathrm{Pt} / \mathrm{CeO}_{2}(\mathrm{C})$ catalyst shows the highest activity and hydrogen selectivity for partial oxidation reaction among all the ceria-supported catalysts. This is because it has the largest BET surface area and the highest platinum dispersion among all the ceria-supported catalyst. The $1 \% \mathrm{Pt} / \mathrm{Al}_{2} \mathrm{O}_{3}$ catalyst gives higher activity and hydrogen selectivity than $1 \% \mathrm{Pt} / \mathrm{CeO}_{2}(\mathrm{C})$ catalyst. This can be explained by the fact that it has BET surface area, twice that of $1 \% \mathrm{Pt} / \mathrm{CeO}_{2}(\mathrm{C})$ and also it shows higher platinum dispersion than that of $1 \% \mathrm{Pt} / \mathrm{CeO}_{2}(\mathrm{C})$.

Studies of the effect of time on stream on the performance of $1 \% \mathrm{Pt} / \mathrm{CeO}_{2}$ (C) and $1 \% \mathrm{Pt} / \mathrm{Al}_{2} \mathrm{O}_{3}$ catalysts at $800{ }^{\circ} \mathrm{C}$ and $600{ }^{\circ} \mathrm{C}$ respectively show that both the catalysts give stable performance for partial oxidation with deactivation rate $0.28 \%$ and $0.25 \%$ propane conversion/hr respectively.

The effect of temperature shows that the reaction contains two domains. In the first domain (below $500{ }^{\circ} \mathrm{C}$ ), the propane is converted into carbon dioxide and water and in the second domain (above $500{ }^{\circ} \mathrm{C}$ ), propane undergoes reforming reaction to produce carbon monoxide and hydrogen.

The study of effect of the $\mathrm{O}_{2} / \mathrm{C}_{3} \mathrm{H}_{8}$ ratio on partial oxidation of propane shows that conversion of propane increases and hydrogen selectivity decreases with increase in the 
$\mathrm{O}_{2} / \mathrm{C}_{3} \mathrm{H}_{8}$ ratio. The optimum $\mathrm{O}_{2} / \mathrm{C}_{3} \mathrm{H}_{8}$ ratio is probably around 2 for high propane conversion and high hydrogen selectivity.

Partial oxidation was studied on the $\mathrm{CeO}_{2}(\mathrm{C})$ and $\gamma-\mathrm{Al}_{2} \mathrm{O}_{3}$ supports alone. Both the supports are active for total oxidation of propane to carbon dioxide and water, with no activity for propane reforming reactions to form hydrogen and carbon monoxide.

Dry reforming of propane is carried out to understand the contribution of dry reforming reaction in the reforming reactions. Results show that dry reforming is not a significant reforming reaction for both $1 \% \mathrm{Pt} / \mathrm{CeO}_{2}(\mathrm{C})$ and $1 \% \mathrm{Pt} / \mathrm{Al}_{2} \mathrm{O}_{3}$ catalysts.

Effect of flow rate was studied for partial oxidation reaction with very low catalyst loadings such as $0.01 \mathrm{~g}$ and $0.02 \mathrm{~g}$. The following reaction scheme can be proposed. Initially propane undergoes total oxidation to form carbon dioxide and water. The unreacted propane undergoes steam reforming to form carbon monoxide and hydrogen. Water gas shift and the reverse Boudouard reactions take place on both catalysts.

Activity ratios are compared with equilibrium constants. The results indicate that water gas shift is near equilibrium for the $1 \% \mathrm{Pt} / \mathrm{CeO}_{2}$ (C) catalyst, but is far from equilibrium for the $1 \% \mathrm{Pt} / \mathrm{Al}_{2} \mathrm{O}_{3}$ catalyst. The reverse Boudouard reaction is close to equilibrium for the $1 \% \mathrm{Pt} / \mathrm{Al}_{2} \mathrm{O}_{3}$ catalyst, but is far from equilibrium for $1 \% \mathrm{Pt} / \mathrm{CeO}_{2}$ (C) catalyst. Activity ratios for the $1 \% \mathrm{Pt} / \mathrm{CeO}_{2}$ (C) are 10 times smaller than those for $1 \%$ $\mathrm{Pt} / \mathrm{Al}_{2} \mathrm{O}_{3}$. Water gas shift dominates over the reverse Boudouard reaction for $1 \% \mathrm{Pt} / \mathrm{CeO}_{2}$ (C), resulting in an increase in carbon dioxide production with decrease in carbon monoxide production at higher flow rates. However, reverse Boudouard dominates over water gas shift for $1 \% \mathrm{Pt} / \mathrm{Al}_{2} \mathrm{O}_{3}$ catalysts resulting in decrease in carbon dioxide production at higher flow rates. The proposed reaction sequence is:

1. Total oxidation of propane

$$
\mathrm{C}_{3} \mathrm{H}_{8}+5 \mathrm{O}_{2} \rightarrow 3 \mathrm{CO}_{2}+4 \mathrm{H}_{2} \mathrm{O} \quad \text { Equation } 7.1
$$


2. Steam reforming of propane in parallel with water gas shift reaction and reverse Boudouard reaction.

$$
\begin{array}{lll}
\mathrm{C}_{3} \mathrm{H}_{8}+3 \mathrm{H}_{2} \mathrm{O} \rightarrow 3 \mathrm{CO}+7 \mathrm{H}_{2} & \text { (Steam reforming) } & \text { Equation 7.2 } \\
\mathrm{CO}+\mathrm{H}_{2} \mathrm{O} \rightarrow \mathrm{CO}_{2}+\mathrm{H}_{2} & \text { (Water gas shift) } & \text { Equation 7.3 } \\
\mathrm{C}+\mathrm{CO}_{2} \rightarrow 2 \mathrm{CO} & \text { (Reverse Boudouard reaction) } & \text { Equation 7.4 }
\end{array}
$$




\subsection{Recommendations for future work}

The effect of flow rate was studied for $0.01 \mathrm{~g}$ catalyst loading. The oxygen was completely consumed even at such a low catalyst loading. Whether partial oxidation of propane is taking place or total oxidation of propane is taking place first can not be found out when the oxygen is completely consumed. So the reaction conditions should be chosen such that there is some oxygen at the outlet which is left unreacted. Some oxygen is observed at outlet of the reactor at lower temperatures $\left(500^{\circ} \mathrm{C}\right.$ and $\left.550{ }^{\circ} \mathrm{C}\right)$. So one option is to carry out experiments at $500{ }^{\circ} \mathrm{C}$ or $550^{\circ} \mathrm{C}$ on the effect of flow rate. These experiment will help to elucidate whether partial oxidation is taking place or total oxidation is taking place first.

Ayabe et al. (2003) studied partial oxidation of propane on $\mathrm{Ni} / \mathrm{Al}_{2} \mathrm{O}_{3}$ catalyst. They observed that addition of steam in the reaction mixture increases hydrogen yield. Addition of steam also suppresses carbon formation. Steam should be added in the propane and oxygen reaction mixture when partial oxidation of propane is carried out on $1 \% \mathrm{Pt} / \mathrm{CeO}_{2}$ (C) or $1 \% \mathrm{Pt} / \mathrm{Al}_{2} \mathrm{O}_{3}$ catalyst to see if it has any effect in increasing hydrogen yield.

Results show that $1 \% \mathrm{Pt} / \mathrm{Al}_{2} \mathrm{O}_{3}$ gives better activity than $1 \% \mathrm{Pt} / \mathrm{CeO}_{2}(\mathrm{C})$. This is due to higher BET surface area and $\mathrm{Pt}$ dispersion of $1 \% \mathrm{Pt} / \mathrm{Al}_{2} \mathrm{O}_{3} .1 \% \mathrm{Pt} / \mathrm{CeO}_{2}(\mathrm{C})$ catalyst showed $35 \% \mathrm{Pt}$ dispersion whereas $1 \% \mathrm{Pt} / \mathrm{Al}_{2} \mathrm{O}_{3}$ catalyst showed $46 \% \mathrm{Pt}$ dispersion. Pantu and Gavalas (2002) have prepared cerium oxide support using the citrate complexation technique. Platinum was added to the support by incipient wetness impregnation and $0.5 \% \mathrm{Pt} / \mathrm{CeO}_{2}$ showed $69 \% \mathrm{Pt}$ dispersion. This method of preparation for ceria support and the catalyst could be used. It could help in getting higher platinum dispersion values and thus getting higher catalyst performance. 
Kinetic studies could be carried out by varying partial pressures of propane and oxygen to find order of reaction. Product gases such as hydrogen, carbon monoxide and carbon dioxide could also be added with reactants to see if they have any inhibitive effects on reaction kinetics. 


\section{References}

- Ahmed H. and Krumpelt M., "Hydrogen from hydrocarbon fuels for fuel cells", Int. J. Hydrogen Energy, 26, 291-301 (2001).

- Ayabe S., Omoto H., Utaka T., Kikuchi R., Sasaki K., Teraoka Y. and Eguchi K., "Catalytic autothermal reforming of methane and propane over supported metal catalysts", Appl. Catal. A, 241, 261-269 (2003).

- Barbier Jr. J. and Duprez D., "Hydrogen formation in propane oxidation on Pt$\mathrm{Rh} / \mathrm{CeO}_{2} / \mathrm{Al}_{2} \mathrm{O}_{3}$ catalysts", Appl. Catal. A, 85, 89-100 (1992).

- Balzhiser R. E. and Samuels M. R., Chemical Engineering Thermodynamics: The study of Energy, Entropy and Equilibrium, Prantice Hall Inc., New Jersey (1972).

- Diwell A. F., Rajaram R. R., Shaw H. A. and Truex T. J., "The role of ceria in three way catalysis", Catalysis and automotive pollution control II, Elsevier science B. V., 139-152 (1991).

- Gjervan T., Venvik H., Aartun I., Holmen A., Gorke O., Pfeifer P. and Schubert K., "Hydrogen production from propane through partial oxidation and autothermal reforming in microstructured reactors", Fuel Chem. Div. Preprints, 48(1), 322-323 (2003).

- Golunski S. E., Hatcher H. A., Rajaram R. R. and Truex T. J., "Origins of lowtemperature three way activity in $\mathrm{Pt} / \mathrm{CeO}_{2}$ ", Appl. Catal. B, 5, 367-376 (1995).

- Grenoble D. C. and Estadt M. M., "The chemistry and catalysis of the water gas shift reaction", Journal of Catalysis, 67, 90-102 (1981). 
- Guimaraes A. L., Dieguez L. C. and Schmal M., "Surface sites of Pd/ $/ \mathrm{CeO}_{2} / \mathrm{Al}_{2} \mathrm{O}_{3}$ catalysts in the partial oxidation of propane", J. Phys. Chem. B, 107, 4311-4319 (2003).

- Hilaire S., Wang X., Luo T., Gorte R. J. and Wagner J., "A comparative study of watergas-shift reaction over ceria supported metallic catalysts", Applied Catalysis A: General, 215, 271-278 (2001).

- Huff M., Torniainen P. M. and Schmidt L. D., "Partial oxidation of alkanes over noble metal coated monoliths", Catal. Today, 21, 113-128 (1994).

- Jovanovic N. N. and Stankovic M. V., "Effect of catalyst preparation on selectivity of high temperature propane oxidation to $\mathrm{CO}$ and $\mathrm{H}_{2}$ ", Appl. Catal., 30, 3-9 (1987).

- Liu S., Xu L., Xie S., Wang Q. and Xiong G., "Partial oxidation of propane to syngas over nickel supported catalysts modified by alkali metal oxides and rare-earth metal oxides", Appl. Catal. A, 211, 145-152 (2001).

- Luengnaruemitchai A., Osuwan S. and Gulari E., "Comparative studies of lowtemperature water-gas shift reaction over $\mathrm{Pt} / \mathrm{CeO}_{2}, \mathrm{Au} / \mathrm{CeO}_{2}$ and $\mathrm{Au} / \mathrm{Fe}_{2} \mathrm{O}_{3}$ catalysts", Catalysis communications, 4, 215-221 (2003).

- Ma L., Trimm D. L. and Jiang C., "The design and testing of an autothermal reactor for the conversion of light hydrocarbons to hydrogen I. The kinetics of the catalytic oxidation of light hydrocarbons", Appl. Catal. A, 138, 275-283 (1996).

- Maillet T., Barbier Jr. J. and Duprez D., "Reactivity of steam in exhaust gas catalysis III. Steam and oxygen/steam conversions of propane on a $\mathrm{Pd} / \mathrm{Al}_{2} \mathrm{O}_{3}$ catalyst", Appl. Catal. B, 9, 251-266 (1996). 
- Otsuka K., Sunada E., Ushiyama T. and Yamanaka I., "The production of synthesis gas by the redox of cerium oxide", Studies in Surface Science and Catalysis, 107, 531-536 (1997).

- Pantu P. and Gavalas G. R., "Methane partial oxidation on $\mathrm{Pt} / \mathrm{CeO}_{2}$ and $\mathrm{Pt} / \mathrm{Al}_{2} \mathrm{O}_{3}$ catalysts", Appl. Catal. A, 223, 253-260 (2002).

- Passos F. B., Oliveira E. R., Rego C. E. E. L., Mattos L. V. and Noronha F. B., "Partial methane oxidation on yttria and ceria supported platinum catalysts", Fuel Chemistry Division Preprints, 48(1), 325-326 (2003).

- Pena M. A., Gomez J. P. and Fierro J. L. G., "New catalytic routes for syngas and hydrogen production", Appl. Catal. A, 144, 7-57 (1996).

- Perrichon V., Laachir A., Abouarnadasse S., Touret O. and Blanchard G., "Thermal stability of a high surface area ceria under reducing atmosphere”, Appl. Catal. A, 129, 69-82 (1995).

- Pino L. Recupero V., Beninati S., Shukla A. K., Hegde M. S. and Bera P., "Catalytic partial-oxidation of methane on a ceria-supported platinum catalyst for application in fuel cell electric vehicles", Appl. Catal. A, 225, 63-75 (2002).

- Pino L., Vita A., Cordaro M., Recupero V. and Hegde M. S., “A comparative study of $\mathrm{Pt} / \mathrm{CeO}_{2}$ catalysts for catalytic partial oxidation of methane to syngas for application in fuel cell electric vehicle", Appl. Catal. A, 243, 135-146 (2003).

- Rampe T. Heinzel A. and Vogel B., "Hydrogen generation from biogenic and fossil fuels by autothermal reforming", J. Power Sources, 86, 536-541 (2000). 
- Ruckenstein E. and Wang H. Y., "Effect of Support on Partial Oxidation of Methane to Synthesis Gas over Supported Rhodium Catalysts", Journal of Catalysis, 187, 151-159 (1999).

- Sandler S. I., Chemical and Engineering Thermodynamics, $3^{\text {rd }}$ edition, John Wiley \& Sons, Inc., New York (1999).

- Solymosi F. and Tolmacsov P., "Decomposition of propane and its reactions with $\mathrm{CO}_{2}$ over alumina-supported Pt metals", Catalysis Letters, 83, 183-186 (2002).

- Stankovic M. V. and Jovanovic N. N., "High temperature propane oxidation to reducing gas over promoted $\mathrm{Ni} / \mathrm{MgO}$ catalysts. Role of impregnation condition and promoter on properties of catalysts", $3^{\text {rd }}$ world congress on oxidation catalysis, Elsevier sciences B.V., 1145-1154 (1997). 


\section{Appendices}




\section{Appendix A: Gas Chromatograph Program}

Gas Chromatograph Model: Varian 3600

Detectors used:

A: Thermal conductivity detector (TCD)

B: Flame ionization detector (FID)

Carrier Gas: Argon

Reference flow: $58 \mathrm{cc} / \mathrm{min}$

Carrier flow: $19 \mathrm{cc} / \mathrm{min}$

Columns used: Haysep D packed column and an alumina capillary column

Period of analysis: 44 minutes

Method 1

Initial column temperature: $35^{\circ} \mathrm{C}$

Initial hold time: 6 minutes

Final column temperature: $200{ }^{\circ} \mathrm{C}$

Column rate in ${ }^{\circ} \mathrm{C} / \mathrm{min}: 5$

Column hold time: 5 minutes

Injector A temperature: $200^{\circ} \mathrm{C}$

Injector B temperature: $100^{\circ} \mathrm{C}$

Detector A temperature: $250{ }^{\circ} \mathrm{C}$

Detector B temperature: $275^{\circ} \mathrm{C}$

TCD A initial attenuation: 8

TCD A filament temperature: $300{ }^{\circ} \mathrm{C}$

TCD A polarity negative

FID B initial attenuation: 8

Initial relays: -1-2-3-4

Program 1 relay time in minutes: 0.30

Program 1 relays: -12-3-4

Program 2 relay time in minutes: 1

Program 2 relays: $-1-2-3-4$ 


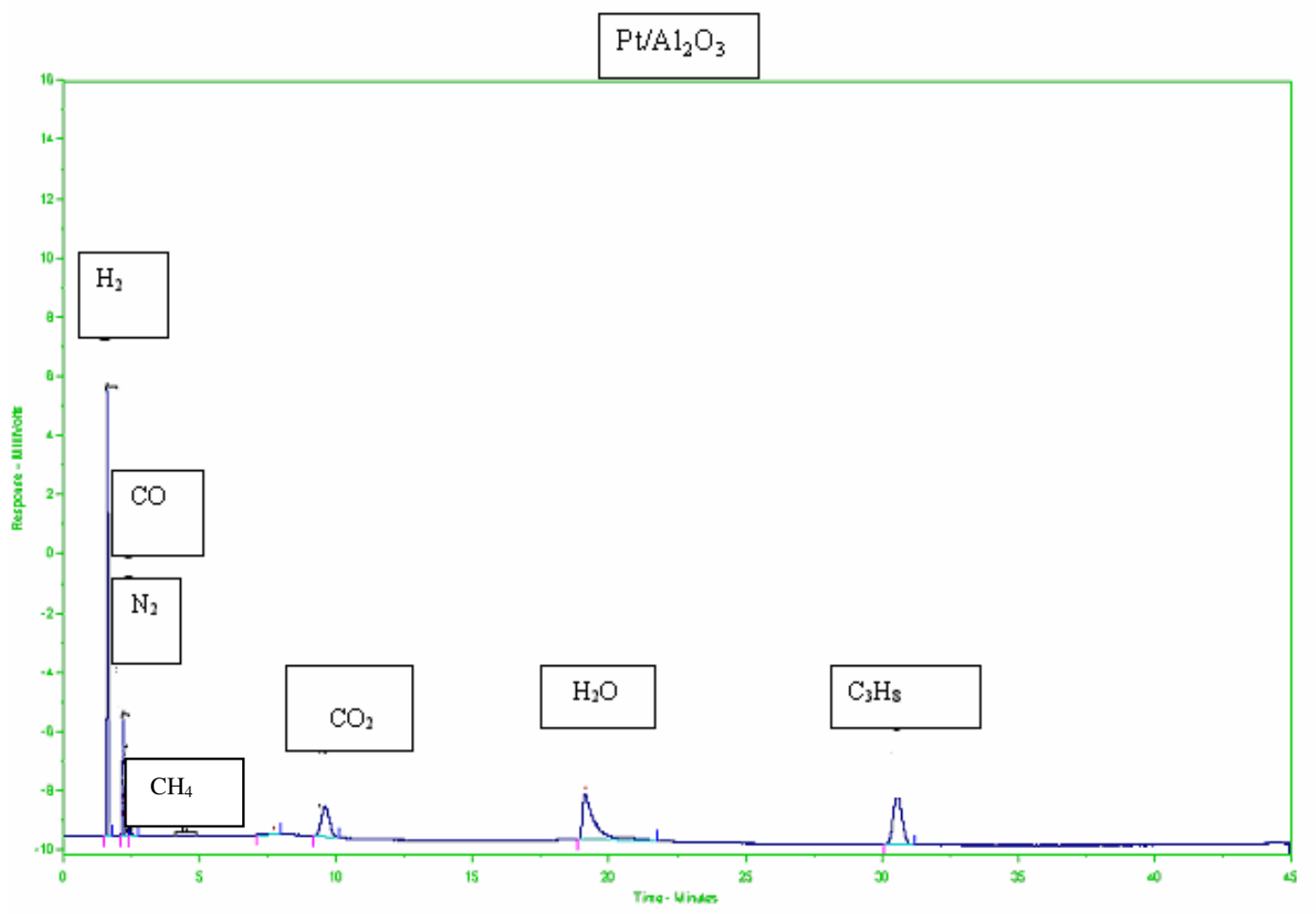

Figure A.1 A typical chromatograph obtained from TCD for partial oxidation of propane over commercial $5 \% \mathrm{Pt}_{/} \mathrm{Al}_{2} \mathrm{O}_{3}$ catalyst (Reaction conditions: $\mathrm{T}=500{ }^{\circ} \mathrm{C}$, Feed ratio $=\mathrm{C}_{3} \mathrm{H}_{8}: \mathrm{O}_{2}: \mathrm{N}_{2}: \mathrm{Ar}=10.8: 19.2: 10.8: 259$ ) 


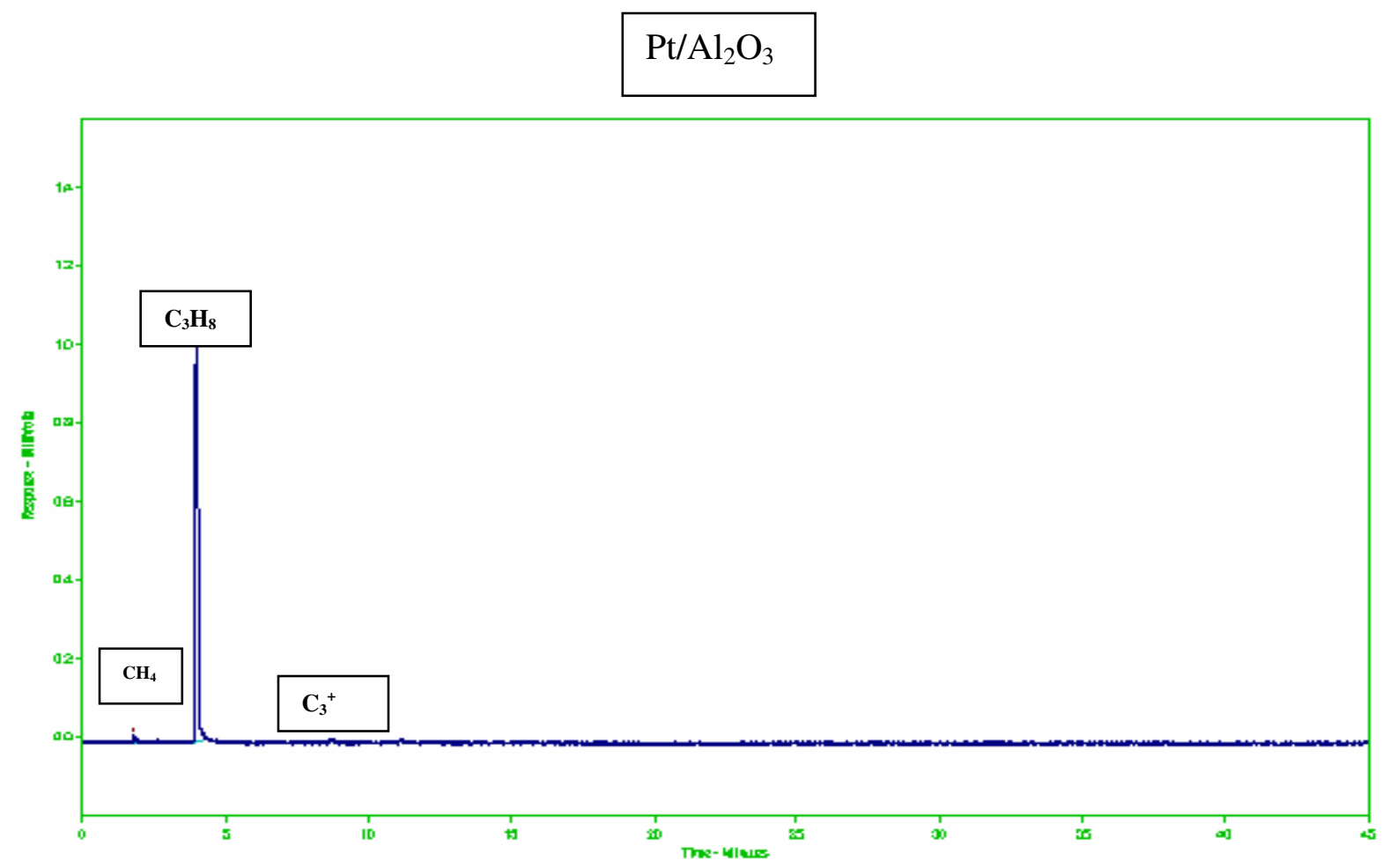

Figure A.2 A typical chromatograph obtained from FID for partial oxidation of propane over commercial $5 \% \mathrm{Pt}_{/} \mathrm{Al}_{2} \mathrm{O}_{3}$ catalyst (Reaction conditions: $\mathrm{T}=500{ }^{\circ} \mathrm{C}$, Feed ratio $=\mathrm{C}_{3} \mathrm{H}_{8}: \mathrm{O}_{2}: \mathrm{N}_{2}: \mathrm{Ar}=10.8: 19.2: 10.8: 259$ ) 


\section{Appendix B: Mass Flow Controller Calibration Curves}

This appendix provides calibration curves for the Brooks mass flow controllers used for reaction of partial oxidation of propane and dry reforming of propane.

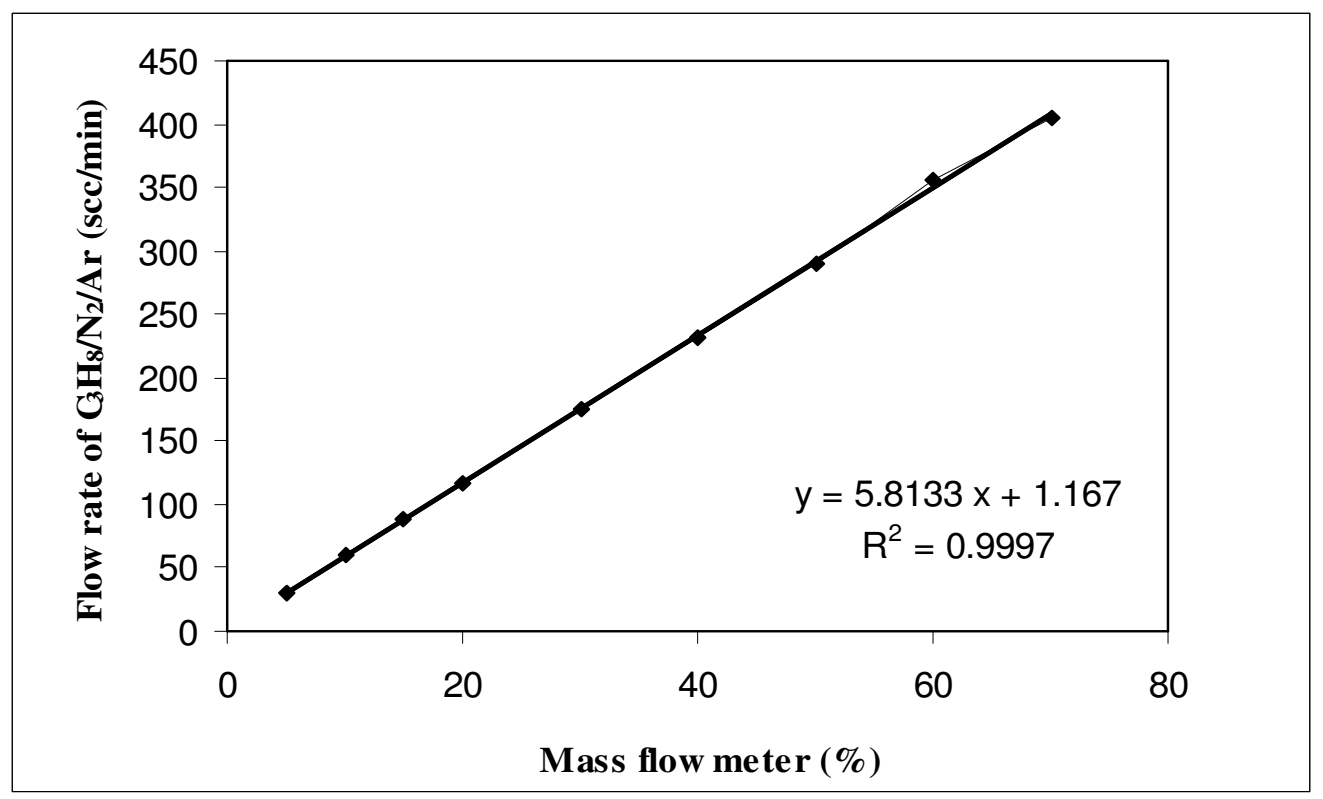

Figure B.1 MFC calibration curve for $\mathrm{C}_{3} \mathrm{H}_{8} / \mathrm{N}_{2} / \mathrm{Ar}$ mixture

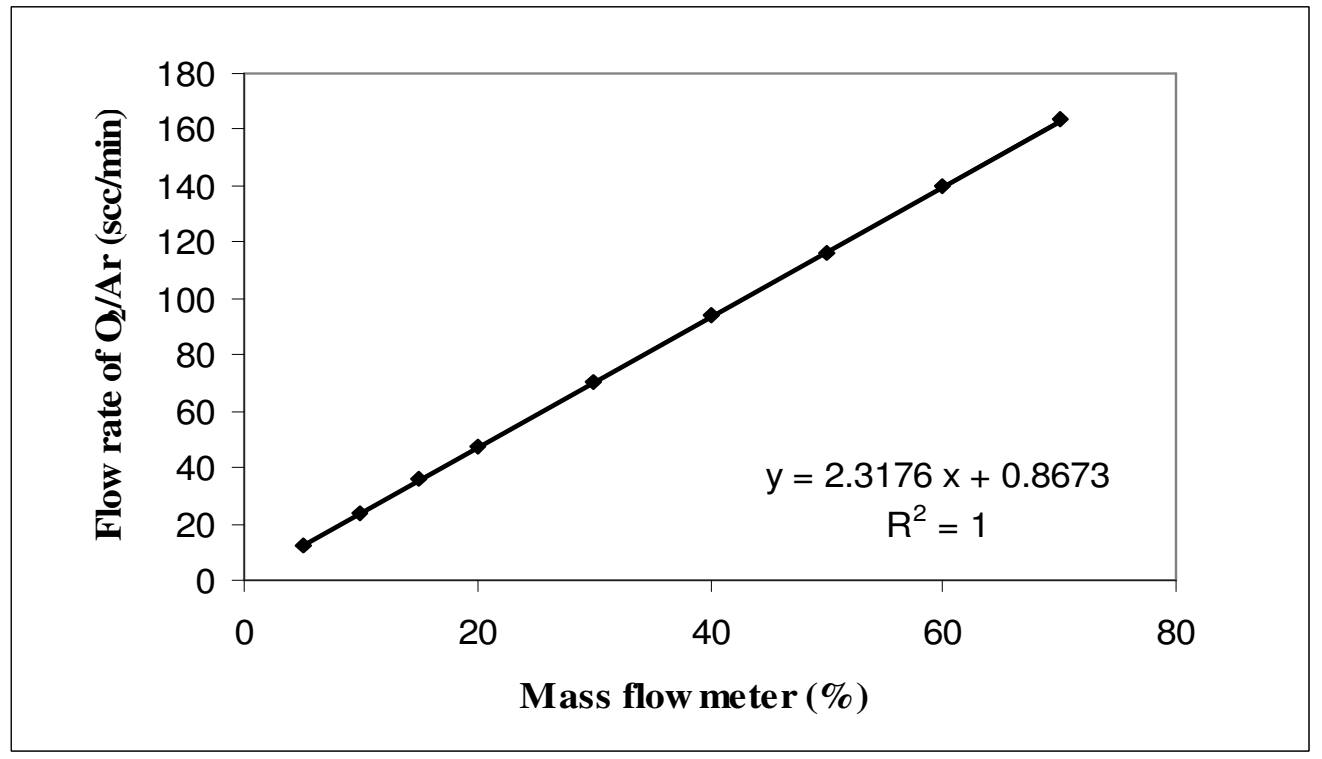

Figure B.2 MFC calibration curve for $\mathrm{O}_{2} / \mathrm{Ar}$ mixture 


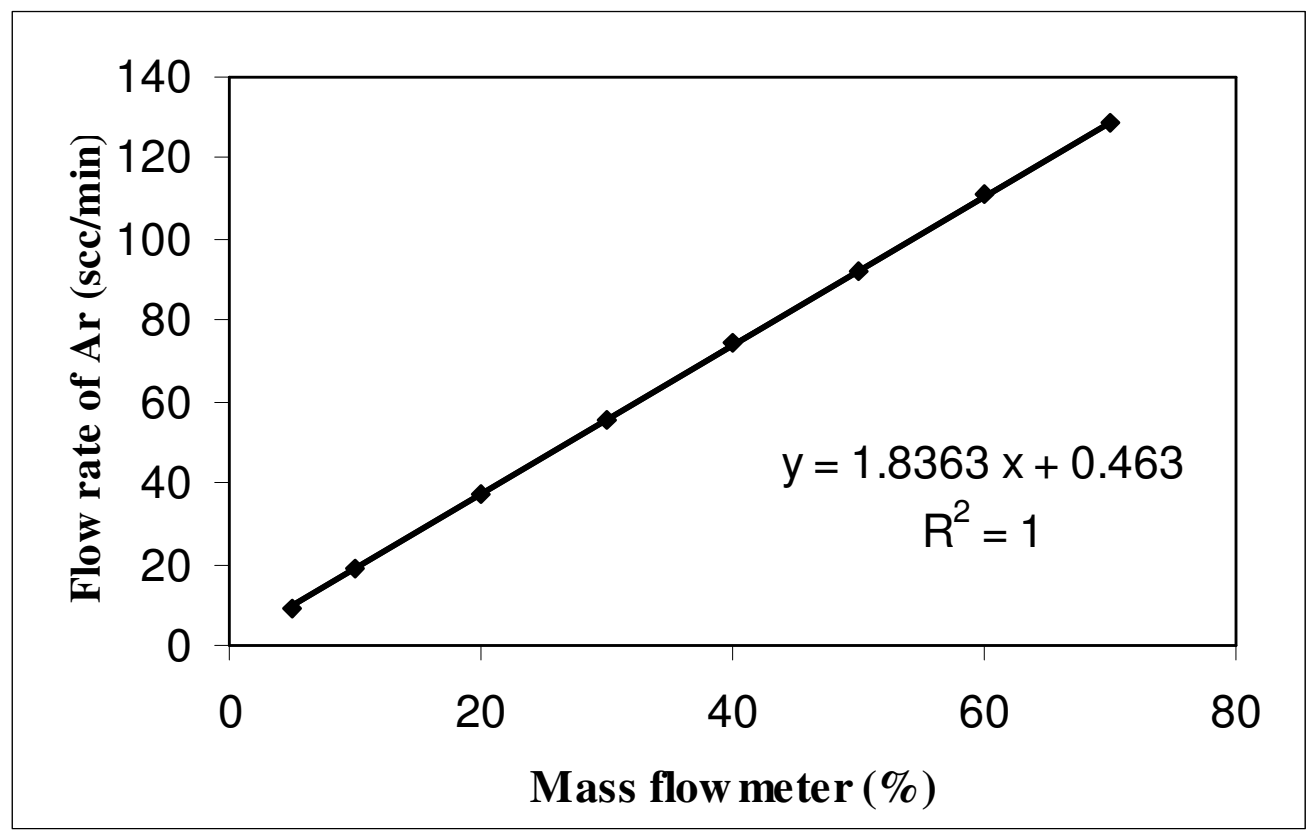

Figure B.3 MFC calibration curve for Ar

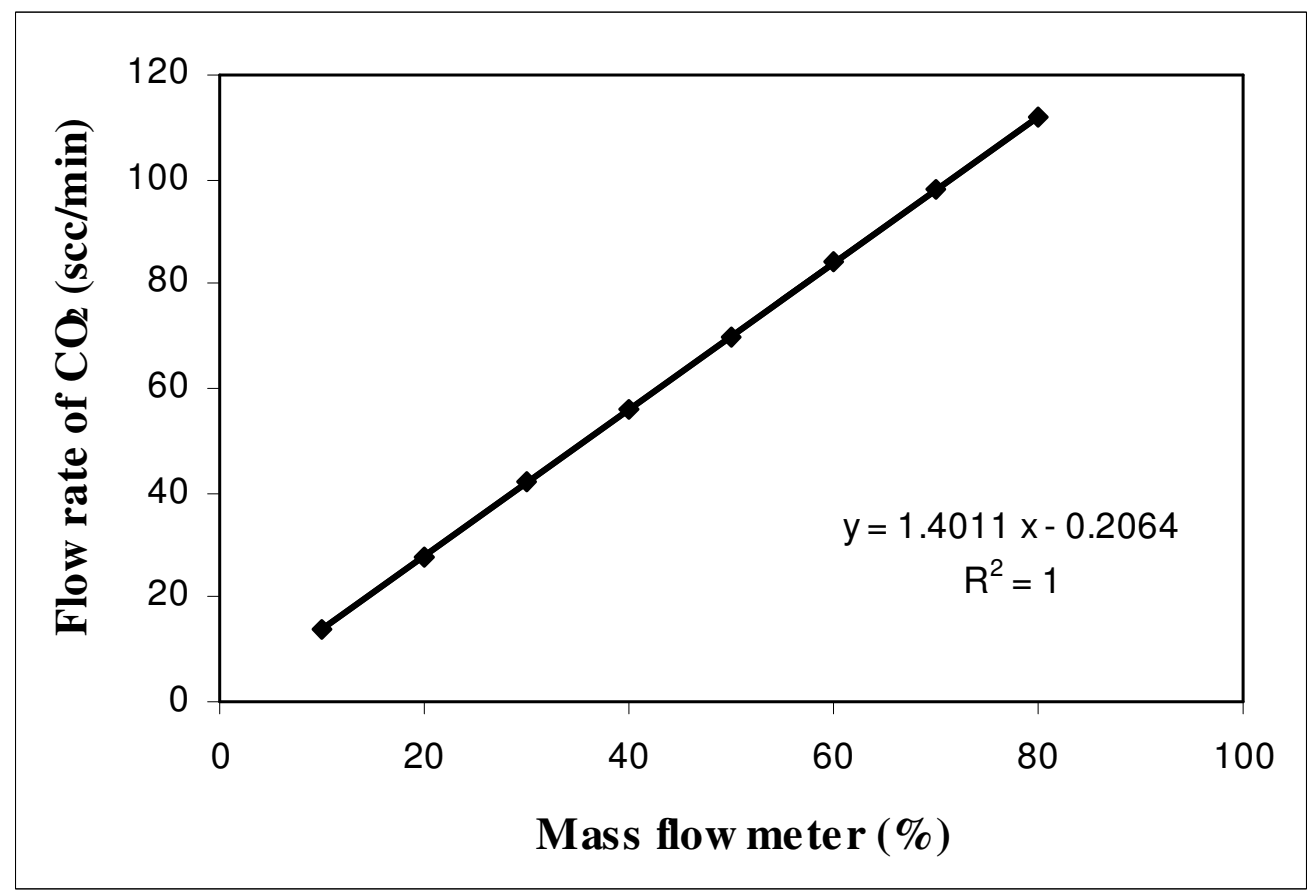

Figure B.4 MFC calibration curve for $\mathrm{CO}_{2}$ 


\section{Appendix C: Calculations for Conversions and Selectivities}

The procedure for calculations of conversions and selectivities is given in this Appendix. The relative response factors for various gases which are detected in TCD detector are given in Table C.1.

Table C.1 Relative response factors for the reactants and products

\begin{tabular}{|c|c|c|}
\hline Gases & Retention time (min) & $\begin{array}{c}\text { Relative response factors } \\
(\mathbf{r R F})\end{array}$ \\
\hline $\mathrm{H}_{2}$ & 3.71 & 0.089 \\
\hline $\mathrm{N}_{2}$ & 4.81 & 1.000 \\
\hline $\mathrm{O}_{2}$ & 4.94 & 0.836 \\
\hline $\mathrm{CO}$ & 5.28 & 0.987 \\
\hline $\mathrm{CH}_{4}$ & 8.45 & 0.269 \\
\hline $\mathrm{CO}_{2}$ & 14.55 & 0.880 \\
\hline $\mathrm{C}_{3} \mathrm{H}_{6}$ & 34.00 & 0.286 \\
\hline $\mathrm{C}_{3} \mathrm{H}_{8}$ & 35.28 & 0.286 \\
\hline
\end{tabular}

Nitrogen is an internal standard. Now outlet flow rate of any gas $(\mathrm{x})$ can be calculated as:

$$
\left(V_{x}\right)_{\text {out }}=\frac{r R F_{X} \times A_{X} \times V_{N_{2}, \text { in }}}{r R F_{N_{2}} \times A_{N_{2}}} \quad(\mathrm{scc} / \mathrm{min})
$$

where,

$A_{X}=$ TCD peak area of component $X$

$A_{N_{2}}=$ TCD peak area of $N_{2}$

$r R F_{X}=$ Relative response factor of component $X$

$r R F_{N_{2}}=$ Relative response factor of component $N_{2}$

$V_{N_{2}, \text { in }}=$ Inlet flow rate of $N_{2}$ in scc/min 
Thus by calculating outlet flow rates of reactant and product gases, conversions and selectivities can be calculated as:

1. Conversion of propane, $X_{C 3 H 8}, \%$

$$
X_{C 3 H 8}=\frac{V_{C 3 H 8, \text { in }}-V_{C 3 H 8, \text { out }}}{V_{C 3 H 8, \text { in }}} \times 100 \quad \text { Equation C.1 }
$$

where

$V_{C 3 H 8, \text { in }}=$ Inlet flow rate of $\mathrm{C}_{3} H_{8}$ in scc/min

$V_{C 3 H 8, \text { out }}=$ Outlet flow rate of $C_{3} H_{8}$ in scc/min

2. Conversion of oxygen, $X_{O_{2}}, \%$

$$
X_{O 2}=\frac{V_{O 2, \text { in }}-V_{O 2, \text { out }}}{V_{O 2, \text { in }}} \times 100
$$

Equation C.2

$V_{O 2, \text { in }}=$ Inlet flow rate of $O_{2}$ in scc/min

$V_{\text {o2, out }}=$ Outlet flow rate of $O_{2}$ in scc/min

3. Selectivity of hydrogen, $S_{H_{2}}, \%$

$$
S_{H 2}=\frac{V_{H 2, \text { out }}}{\left[V_{C 3 H 8, \text { in }}-V_{C 3 H 8, \text { out }}\right]^{* 4}} \times 100
$$

Equation C.3

$V_{H 2, \text { out }}=$ Outlet flow rate of $\mathrm{H}_{2}$ in scc/min

4. Selectivity of carbon monoxide, $S_{C O}, \%$

$$
S_{C O}=\frac{V_{C O, \text { out }}}{\left[V_{C 3 H 8, \text { in }}-V_{C 3 H 8, \text { out }}\right] * 3} \times 100
$$

Equation C.4

$V_{C O, \text { out }}=$ Outlet flow rate of $C O$ in scc/min 
5. Selectivity of carbon dioxide, $\mathrm{S}_{\mathrm{CO} 2}, \%$

$$
S_{C O 2}=\frac{V_{C O 2, \text { out }}}{\left[V_{C 3 H 8, \text { in }}-V_{C 3 H 8, \text { out }}\right] * 3} \times 100
$$

Equation C.5

$V_{\mathrm{CO} 2, \text { out }}=$ Outlet flow rate of $\mathrm{CO}_{2}$ in scc/min

6. Selectivity of methane, $S_{\mathrm{CH}_{4}}, \%$

$$
S_{C H 4}=\frac{V_{C H 4, \text { out }}}{\left[V_{C 3 H 8, \text { in }}-V_{C 3 H 8, \text { out }}\right] * 3} \times 100
$$

Equation C.6

$V_{C H 4, \text { out }}=$ Outlet flow rate of $\mathrm{CH}_{4}$ in scc/min 